University of Rhode Island

\title{
DigitalCommons@URI
}

Open Access Dissertations

2018

\section{Three Essays on Corporate Asset Growth, Bond Pricing, and Implicit Government Guarantees}

Yifei Li

University of Rhode Island, yifei1019@uri.edu

Follow this and additional works at: http://digitalcommons.uri.edu/oa_diss

Terms of Use

All rights reserved under copyright.

\section{Recommended Citation}

Li, Yifei, "Three Essays on Corporate Asset Growth, Bond Pricing, and Implicit Government Guarantees" (2018). Open Access Dissertations. Paper 728.

http://digitalcommons.uri.edu/oa_diss/728

This Dissertation is brought to you for free and open access by DigitalCommons@URI. It has been accepted for inclusion in Open Access Dissertations by an authorized administrator of DigitalCommons@URI. For more information, please contact digitalcommons@etal.uri.edu. 
THREE ESSAYS ON CORPORATE ASSET GROWTH, BOND PRICING, AND IMPLICIT GOVERNMENT GUARANTEES

BY

YIFEI LI

A DISSERTATION SUBMITTED IN PARTIAL FULFILLMENT OF THE REQUIREMENTS FOR THE DEGREE OF DOCTOR OF PHILOSOPHY

IN

BUSINESS ADMINISTRATION

UNIVERSITY OF RHODE ISLAND

2018 
DOCTOR OF PHILOSOPHY DISSERTATION

$\mathrm{OF}$

YIFEI LI

\title{
APPROVED:
}

Dissertation Committee:

\author{
Major Professor Tong Yu \\ Shaw Chen \\ Georges Tsafack \\ Jingjian Xiao \\ Nasser H. Zawia \\ DEAN OF THE GRADUATE SCHOOL
}

\section{UNIVERSITY OF RHODE ISLAND}




\begin{abstract}
The purpose of my dissertation is to identify factors driving corporate bond pricing and government guarantees on corporate liabilities. In the first manuscript, I identify the driving sources of asset growth from the perspective of debt financing and examine the asset growth effect on bond pricing. There are competing views on potential drivers for corporate asset growth. Researchers in favor of optimal investment attributes a higher asset growth rate to lower cost of capital and richer investment opportunities. Alternatively, the agency problem argument attributes high asset growth to over-investments. Building on that firms often heavily rely on debt to grow their assets, we differentiate these perspectives by studying the relation between the bond yields and issuers' asset growth rates. We do not find that yields of bonds issued by high asset growth firms are lower than those of low-growth firms. Moreover, we find that bonds issued by high asset growth firms are potentially overvalued - they experience poor performance in years afterwards. Overall, the results are aligned with the agency problem explanation for corporate asset growth.

The second manuscript offers a novel approach to estimate the value of the implicit government guarantee by combining the contingent claim pricing with the likelihood of the government intervention. We find in our sample that the cost of this implicit protection can go beyond tens of billions of dollars with an average of about $\$ 13$ million per company, per year, and it rises to about $\$ 24$ million if the government is assumed to intervene with certainty. We then investigate the relationship between the implicit government guarantee and the funding costs of small and large banks. The funding costs for both small and large banks are related to the value of the implicit government guarantee. Moreover, we show that the spread of the funding costs of small banks over large banks is strongly associated
\end{abstract}


with the value of the implicit government guarantee, especially after the crisis.

The corporate bond sector has grown tremendously over the past decade. Rapid growth in Chinese corporate indebtedness and corporates ability to pay back their liabilities have become a persistent concern for regulators and investors in recent years. In the third manuscript, we examine the determinants of the pricing of Chinese corporate bonds and potential agency costs arising from implicit government guarantees (IGG) for state owned enterprises (SOEs). We show that the yield of central government SOE bonds is 85 bps lower than that of nonSOE bonds after controlling for firm-specific, bond-specific characteristics, and macroeconomic variables. Further, quantifying IGG with (the lack of) bond yield sensitivity to equity volatility, we present evidence on the dark side of IGG high IGG firms are subject to greater agency costs; they are more likely to over-invest to negative NPV project, suffering poor operating performance. 


\section{ACKNOWLEDGMENTS}

My Ph.D. thesis dissertation would have never been possible without the guidance and support of various people. I take this opportunity to express my sincere gratitude to my professors, colleagues, family and friends.

I would like to express my special appreciation and thanks to my advisor Professor Dr. Tong Yu, you have been a tremendous mentor for me. Your advice on both research as well as on my career have been invaluable. I am extremely grateful for Dr. Yu's valuable input, academic guidance and continuous encouragement to my work. He pushed me to go ahead, taught me to value my time, and trained me how to do research as well as many more things than I could have expected from an advisor. Without his guidance and persistent help, this thesis would not have materialized.

Special thanks are also given to Dr. Shaw Chen who is my co-adviser on my defense committee. Dr. Chen has always been helpful in critical moments of my Ph.D. study and I would like to express my sincere appreciation to all his wise suggestions. I also feel grateful to have an exceptional defense committee, and wish to thank Dr. Georges Tsafack, Dr. Jing Jian Xiao, and Dr. Sun Yan. I am indebted to many of my professors who support me, especially Dr. BingXuan Lin. Dr. Lin's seminar has laid solid foundation for my work and have broadened my ideas on research topics.

My genuine thanks also go to Dr. Zhenzhen Sun (University of Massachusetts, Dartmouth), Dr. Xuanjuan Chen (Shanghai University of Finance and Economics) and Dr. Ran Zhang (University of Science and Technology, Beijing). I would also like to thank all other Ph.D. students from the College of Business. I recall the days that we exchanged ideas and even just chatted together to relax from the heavy study load. All these moments made my Ph.D. study more memorable. 
I have been blessed with a very loving and supportive family. My father Gang Li, and mother Yan Hou are the most supportive parents that you can think of. They always put their sons study and career as the priority and I do feel guilty not be able to see them very often. The last two people I want to thank are my wife Anni Wang and my son Corey. I need to thank my baby boy for being such a bundle of joy and laughter. As for my wife Anni, she is the most enthusiastic cheerleader; she is my best friend; and she is a wonderful wife and mother. Anni has seen through the ups and downs of my Ph.D. study and I am grateful for her dedication to our family.

I will forever cherish the memorable years of life at the University of Rhode Island. My appreciation is beyond words. 


\section{PREFACE}

Manuscript format is in use. 


\section{TABLE OF CONTENTS}

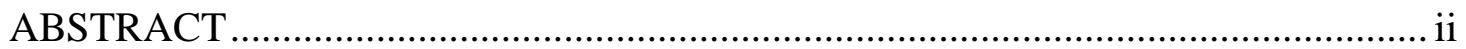

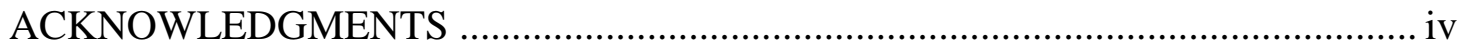

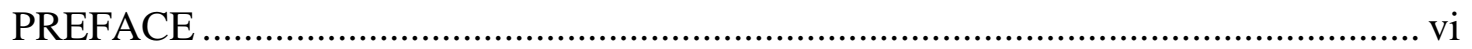

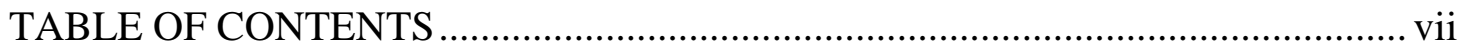

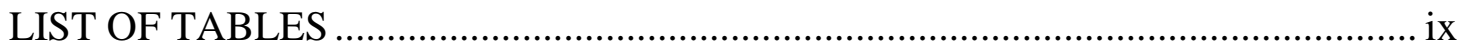

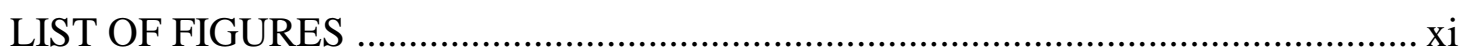

MANUSCRIPT 1

Corporate Asset Growth, Debt Financing, and Bond Performance ................................. 1

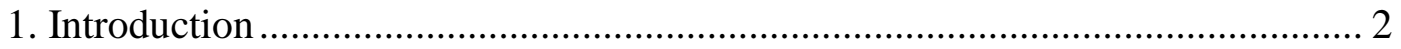

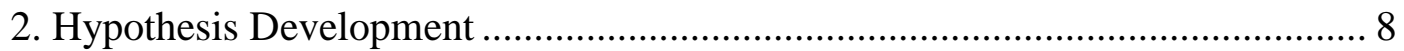

3. Data and Summary Statistics .................................................................. 12

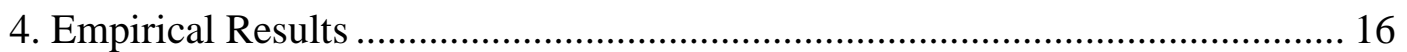

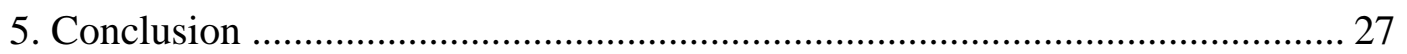

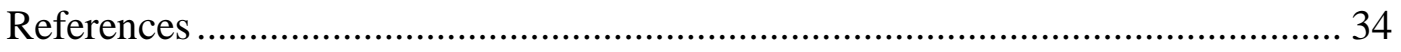

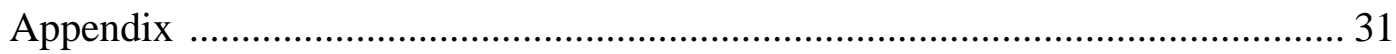

\section{MANUSCRIPT 2}

Too-Big-to-Fail: The Value of Implicit Government Guarantee................................. 58

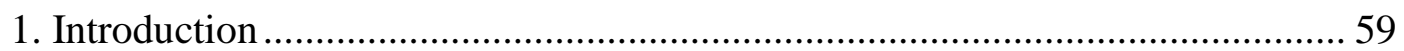

2. Estimation of the Value of the Implicit Government Guarantee ......................... 65

3. Government Guarantee and the Funding Costs ............................................. 71

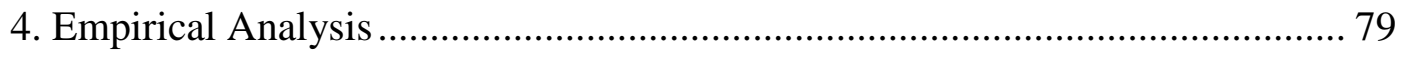

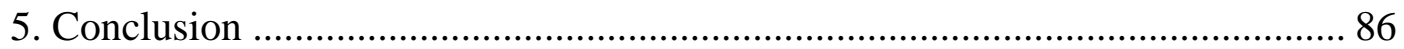




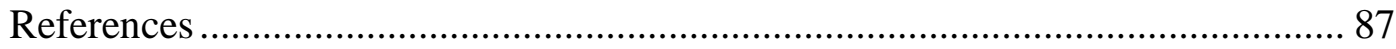

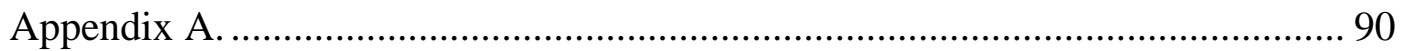

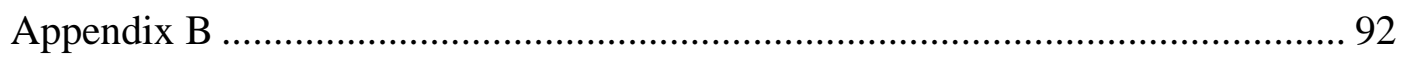

MANUSCRIPT 3

Implicit Government Guarantees in the Bond Market: Chinese Evidence ............... 105

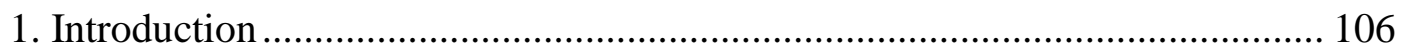

2. Background and Literature Review ....................................................... 109

3. Empirical Framework and Hypotheses ................................................... 113

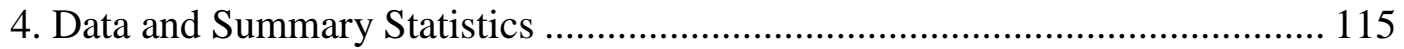

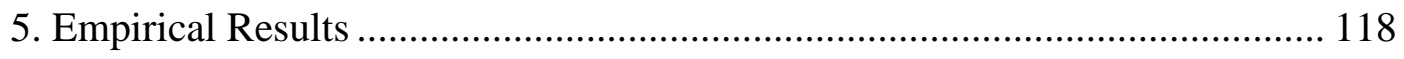

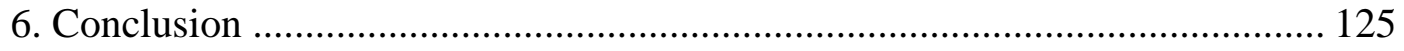

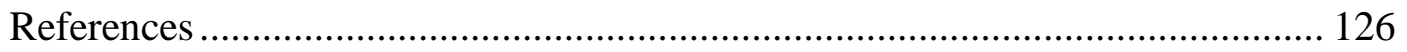




\section{LIST OF TABLES}

TABLE

PAGE

\section{MANUSCRIPT 1}

Table 1. Summary Statistics

Table 2. Asset Growth Deciles: Bond Issuer and Issue Characteristics .................... 42

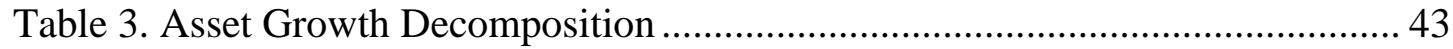

Table 4. Yield Spread Portfolios and Asset Growth .............................................. 44

Table 5. Asset Growth Decile Portfolios and Yield Spread .................................... 45

Table 6. Asset Growth and Its Determinants ...................................................... 46

Table 7. Asset Growth Deciles: Yield and Yield Spread Changes ........................... 47

Table 8. Asset Growth Effect on Yield Spread Changes ......................................... 48

Table 9. Asset Growth Effect: Pre-crisis, Crisis and Post Crisis Periods .................. 49

Table 10. Asset Growth Effect: Investment Grade and Speculative Grade Bonds..... 50

Table 11. Regression Results: Asset and Financing Decompositions ...................... 51

Table 12. Asset Growth and Bond Performance.................................................... 52

MANUSCRIPT 2

Table 1. Summary Statistics for Bailed Out and Bankrupt Firms. ........................... 93

Table 2. Logit Regression for the Probability of the Government Intervention ......... 94

Table 3. Summary Statistics of Company Level Data and Funding Cost Variables .. 95

Table 4. Summary Statistics of Time-Series Variables ........................................... 96

Table 5. Implicit Government Guarantee and BHC Funding Cost .......................... 97

Table 6. Implicit Government Guarantee and BHC Funding Cost Difference........... 98

Table 7. Implicit Government Guarantee and FDIC Funding Cost .......................... 99 
Table 8. Implicit Government Guarantee and FDIC Funding Cost Difference

\section{MANUSCRIPT 3}

Table 1. Numbers and Amount of Bonds Issue in China......................................... 128

Table 2. Bond Yields and Bond Issue Types ......................................................... 129

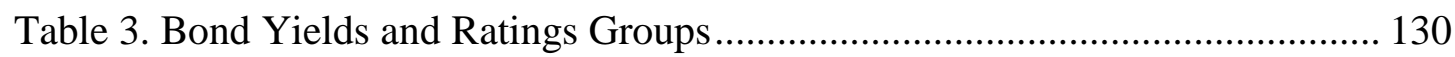

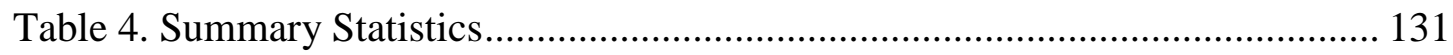

Table 5. Regression of Bond Yields on Bond Specific Variables ............................. 132

Table 6. Regression of Bond Yields on Firm Specific Variables .............................. 133

Table 7. Regression of Bond Yields on Equity Volatility ....................................... 134

Table 8. Regression of IGG and Operating Profitability and Efficiency …............... 135

Table 9. Regression Results of IGG Effect on Stock Performance ........................... 136 


\section{LIST OF FIGURES}

FIGURE

PAGE

MANUSCRIPT 2

Figure 1. Funding Cost Difference: Bank Holding Companies verses FDIC banks. 101

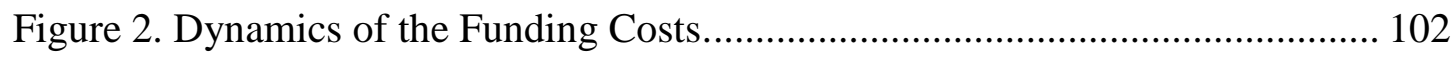

Figure 3. Evolution of the Value of the Implicit Government Guarantee and Interest

Rate 103

Figure 4. The Crisis Effect on the Value of Implicit Government Guarantee 104 MANUSCRIPT 3

Figure 1. Operating Performance and Issuer Types........................................... 137

Figure 2. Stock Performance and Issuer Types............................................... 138 


\title{
Manuscript 1
}

Prepared for submission to Journal of Finance.

\section{Corporate Asset Growth, Debt Financing, and Bond Performance}

\begin{abstract}
There are competing views on potential drivers for corporate asset growth. Researchers in favor of optimal investment attributes a higher asset growth rate to lower cost of capital and richer investment opportunities. Alternatively, the agency problem argument attributes high asset growth to over-investments. Building on that firms often heavily rely on debt to grow their assets, we differentiate these perspectives by studying the relation between the bond yields and issuers' asset growth rates. We do not find that yields of bonds issued by high asset growth firms are lower than those of low-growth firms. Moreover, we find that bonds issued by high asset growth firms are potentially overvalued - they experience poor performance in years afterwards. Overall, the results are aligned with the agency problem explanation for corporate asset growth.
\end{abstract}




\section{Corporate Asset Growth, Debt Financing, and Bond Performance}

\section{Introduction}

Firms differ substantially in their asset growth rates. Based on the Compustat database, from 1994 to 2014 the average asset growth rate weighted by corporate market capitalization for firms in the top corporate asset growth decile group is $62 \%$ while the average asset growth rate of firms in the bottom decile group is $-18 \%$. What may account for the large difference in corporate asset growth? This is a very important issue to corporate profitability and efficiency. Regarding this topic, people heatedly debate about whether there is an optimal asset growth and how is asset growth associated with costs of capital and firm growth opportunities. Researchers in favor of rational expectation suggest that asset growth is a realization of a firm's growth opportunities. Thus, firms with better investment opportunities and a relatively lower cost of capital would have a higher asset growth rate (see, e.g., Hou, Xue, Zhang, 2015). On the other hand, behavioral economists attribute firm asset growth to over-investments - if managers have empire-building incentives, they may fund investment projects beyond the level that maximizes shareholders' value (Jensen and Meckling, 1976; Jensen, 1986). Under this view, corporate asset growth may not be negatively associated with the costs of capital.

The optimal-investment and over-investment explanations have the same prediction on corporate investment: asset growth and future stock performance are negatively associated with each other. Such equivalence makes it hard to differentiate between alternative explanations; To date the literature based on stock performance remains unsettled on the main drivers for corporate asset growth. ${ }^{1}$

\footnotetext{
${ }^{1}$ Researchers in the behavioral camp attribute investors' excessive extrapolation on past growth to the negative asset growth effect on equity returns (e.g., Lakonishok, Shleifer, and Vishny, 1994; Titman, Wei, and Xie, 2004; Cooper, Gulen and Schill, 2008). Alternatively, researchers in the rational expectation camp focus on the association between investment and expected return (Cochrane 1991, 1996; Li, Livdan, and Zhang, 2009; Liu, Whited, and Zhang,
} 
In this study, we shed direct light on the debate by analyzing yields and performance of corporate bonds. The key rationale lies in that corporates heavily rely on debt financing to grow assets. Therefore, bond yield is potentially a good proxy for a firm's marginal cost of capital. Further, a careful examination of bond yields helps us understand the relationship between bondholders and shareholders, a critical source of agency conflicts. Moreover, biased investor beliefs play a role in determining the value of corporate bonds. Recent studies show that bond investors may overextrapolate past growth realizations in corporate bond markets, leading to time-varying mispricing of corporate bonds (Greenwood and Hanson, 2013; Greenwood and Shleifer, 2014; and Greenwood, Hanson and Jin, 2016). Such excessive extrapolation results in overvaluation of firms with high past growth and these expectations will be revised after a period of relatively low asset growth, resulting in a sharp decline in bond price.

Empirical predictions under rational expectation and agency problem explanations are starkly different. Optimal investment suggests a negative relation between yield spread and corporate asset growth, i.e. high asset growth firms tend to have low yield spread holding expected cash flow constant. In contrast, the agency problem explanation indicates that high asset growth firms are not necessary to be those with low cost of capital due to the over-investment and empire-building tendencies. Further, when investors act irrationally and invest in overpriced bonds, we expected a positive asset growth effect on yield changes after the asset growth year. In other words, we expect to see that yields of corporate bonds increase afterwards for high asset growth firms.

How much does a high asset growth firm use debt to finance their growth? To address this question, we breakdown firm asset growth into major financing side of the balance sheet. All firms combined, the contribution of retained earnings to 2009). High asset growth implies low cost of capital, predicting low future stock returns. 
financing activities of asset growth is $30 \%$ and the contribution of debt financing is $74 \%$ for value weighted portfolios. In contrast, the contribution of equity is $-4 \%$. Moreover, for firms in the top ten percentile of asset growth rates, nearly $80 \%$ of financing activities of asset growth comes from debt; $8 \%$ is from internal funds (i.e, retained earnings); new equity financing accounts for $12 \%$ of grown assets. These findings confirms that high asset growth firms heavily reply on debt financing, justifying the use of corporate bond yields as a proxy for the firm's marginal cost of capital.

We examine the determinants of asset growth rates by performing several sorts. First sorting on lagged bond yields, we find an inverse U-shaped between yield spread ranks and asset growth rates. Highest asset growth rates are not firms in the lowest yield spread group. We then control for asset growth in the prior year and check the relation between asset growth rates and lagged yield spreads. Again, higher asset growth rates are not firms with relatively lower yield spreads. The finding does not support the optimal investment argument. Second, we sort firms based on asset growth rates and look at the yield spreads prior to portfolio formations. Here we identify a U-shaped relation between corporate bond yield spreads and corporate asset growth rates. Finally, to control for the effects of growth opportunities and bond credit risk, we construct two-way sorts based on asset growth rates and lagged returns on earnings (ROEs) (a measure of firm growth opportunities used in Hou, Xue, and Zhang, 2015) and on asset growth rates and bonds' credit rating. The finding still suggests a nonlinear relationship between lagged bond yields and firm asset growth rates.

We perform further analysis at the firm level to control for other factors that potentially influence asset growth. The dependent variable is firm asset growth rates. Besides lagged bond yield spreads, other explanatory variables include 
squared yield spreads, firm size, leverage, ROE, credit ratings, and bond maturity. The coefficient on squared yield spreads captures the nonlinear relation between lagged bond yield spreads and asset growth rates. We find that, consistent with conventional wisdom, firm size is negatively associated with asset growth. Also, asset growth are significantly positively associated with firm ROEs, suggesting asset growth to be positively related to future cash flow. Most importantly, we find the coefficient on yield spreads is significantly negative while the coefficient of squared yield spreads is significantly positive. There is a U-shaped relationship between asset growth rates and yield spread in the prior period.

What does the U-shaped relation tell us? It says that when the lagged yield spread is low, corporate asset growth tends to be high. On the other hand, when the lagged yield spread is high, corporate asset growth also tends to be high. This basically suggests that when a firm has relatively low cost of debt, it may issue more debt and pursue higher asset growth. This is consistent with the optimal investment story. However, when a firm has a relatively high cost of debt, the optimal investment rule no longer applies. This potentially suggests a role of the agency problem based explanation for asset growth.

We look at, the bond level, how corporate asset growth rates affect yield spread changes in the year after the asset growth formation year. Note that the yield spread changes and bond performance in years afterwards help us identify if information asymmetry between corporate insiders and bond investors indeed exists. If bond investors are fully aware of issuers' incentives, we would see that bond yields stay constant after the asset growth year. ${ }^{2}$ On the other hand, when investors cannot see through issuers' incentive, we may observe the yields of bonds issued by high-asset growth firms significantly drop in years afterwards. Our empirical

\footnotetext{
${ }^{2}$ From the firm perspective, if a firm decides to issue bonds to finance asset growth when bond investors have the ability to see through managerial incentive, it pays a relatively high cost to raise money. The risk appetite of such firms would be high.
} 
findings support the latter. We document a strong positive relation between asset growth and yield spread changes after controlling for bond-specific characteristics, firm-specific characteristics and macroeconomic factors. One percent increase in asset growth rate is associated with 0.3 basis point increase in yield spread. Furthermore, we find that the asset growth effect on bond yield spread changes remains intact separately for firms with positive and negative asset growth rates. For negative asset growth firms, a positive relation between asset growth rates and yield spread changes indicates the most negative asset growth firms actually have a most negative adjustment in bond yields. It appears that investors over-react to the negative asset growth rates in year t (by setting a higher yield spread) and correct it afterwards.

Our sample is rich in the sense that it includes the financial crisis period and bonds of different credit quality, allowing us to perform further analysis. First, we breakdown the entire sample period into three sub-periods: i) pre-crisis, ii) crisis, and iii) post-crisis. We find that asset growth is negatively associated with yield spread changes during the crisis period, while asset growth is positively associated with yield spread changes during non-crisis period. The implication is that corporate managers are more cautious in their investments and are less likely to overinvest during financial crisis. Meanwhile, investors tend to be rational and make conservative investments when market condition is hard. We show that asset growth has a negative effect on yield spread changes during financial crisis when the agency problem and over-investment tendency are less pronounced. Second, we separately look at the asset growth effects among investment grade and speculative grade bonds. We show that the asset growth effect remains positive in both rating categories.

Finally, we address the question whether asset growth can forecast excess 
corporate bond return, which is estimated 6 months after the formation of asset growth portfolios. Controlling for both bond and firm specific variables, we find that asset growth is negatively associated with future bond return. A standard deviation increase in asset growth is associated with $0.5 \%$ decrease in bond annual bond return. Note that bond return consists of two elements: one related to yield spread changes and the other related the level of bond yields. As we are interested in the change in bond yields after the asset growth measurement year, we further decompose bond returns into these two elements. The finding indicates that the negative association between bond return changes and asset growth rates is mainly attributed to yield changes. Overall, our findings are in aligned with the agency problem based explanation.

This paper contributes to the current literature of asset growth effect and corporate bond pricing in several ways. First, we investigate the potential driving sources of asset growth using corporate bond data. Using yield spread as the proxy of cost of capital, we empirically distinguish rational investment expectation and over-investment explanation by examining bond yields and corporate asset growth. The existing literatures have debated whether asset growth anomaly is due to over-investment or the evidence of rational expectation (Cooper, Gulen and Schill, 2008; Lipson, Mortal and Schill, 2011; and Watanabe, Xu, Yao and Yu, 2013). Our evidence suggests that the asset growth effect is more likely due to the agency explanation of corporate bonds pricing rather than rational expectation. Second, we extend the study to changes in yield spreads. Collin-Dufresne et al. (2001), Campbell and Taksler (2003), and Chen et al. (2007) show that macroeconomic factors, equity volatility and liquidity are important determinants of yield spread changes. We find that an increase in asset growth is significantly and positively associated with yield spread regardless of controlling for changes in credit rating, 
liquidity, macroeconomic influences, or other firm specific factors. The explanatory power of asset growth persists for both investment grade and speculative grade bonds. Third, this study is among the first to examine mispricing of individual bonds. Using aggregate bond data, Greenwood and Hanson (2013) show that investors tend to overextrapolate past growth realizations, leading to mispricing of corporate bonds. In contrast, we extend the study of mispricing of corporate bond pricing literature by examining the performance of individual bonds.

The remainder of our paper is organized as follows. Section 2 develops the hypothesis. Section 3 introduces data and summary statistics. Section 4 explores the driving sources of asset growth and examines the asset growth effect on bond performance. Finally, section 5 concludes.

\section{Hypothesis Development}

In the pioneer works, Brainard and Tobin (1968) and Tobin (1969) argue that the rate of investment should be related to its $q$, which is defined as the value of capital relative to its replacement cost. Firms choose to invest in a project when its q exceeds 1 . This is the so-called q theory of investment. Subsequently, Hayashi (1982) shows that in a perfect competition and constant returns to scale economy, a firm's marginal q (the market value of an additional unit of capital divided by its replacement cost) is equal to its average $q$ (the market value of existing capital divided by its replacement cost). ${ }^{3}$ Cochrane (1996), Liu, Whited and Zhang (2009) and subsequent works derive the q-theory implications for cross-sectional investment returns, which are tied directly to expected returns of individual stocks to firm asset growth and growth opportunities. The logic is following: firms with greater investment opportunities are more likely to make large investments, i.e. experiencing greater asset growth. Nevertheless, holding firm growth opportuni-

\footnotetext{
${ }^{3}$ In fact, there are supports to the q-theory implications. See e.g., Cochrane $(1991 ; 1996)$.
} 
ties constant, firms with lower cost of capital will engage in greater investments, and vice versa. Therefore, the q-theory of investment predicts an inverse relation between investments and expected stock returns, holding growth opportunities constant.

There is evidence on the inverse relation between asset growth rates and stock performance in the subsequent period. For instance, Hou, Xue, and Zhang (2015) propose a four-factor asset pricing model based on q-theory and find this empirical factor model can well capture a broad cross section of stock returns. ${ }^{4}$ Nevertheless, as noted in the literature, stock performance does not necessarily reflect expected returns. For instance, Greenwood and Shleifer (2014) show that stock returns are inversely related to investor expectations of future stock market returns. This raises serious concerns on the implication of empirical findings in explaining the q-theory implication in the link between asset growth and stock returns. Consequently, various studies alternatively use bond returns to derive equity prices and examine equity pricing models (Campello, Chen and Zhang, 2008 and Phillipon, 2009).

Our study follows the same spirit as Campello, Chen and Zhang (2008) and Phillippon (2009). According to the pecking order theory in corporate finance, firms are more likely to use debt to finance a firm's asset growth rather than to issue equity. In particular, when debt is used for asset growth, the cost of capital is correlated with cost of debt. A higher marginal cost of debt leads to a lower future bond performance. In addition, after a relatively high asset growth, marginal $\mathrm{q}$ is decreasing, leading to a lower cost of capital.

Following the investment-based model of Liu, Whited and Zhang (2009), firms choose optimal investment to maximize the market value of equity. Let $\prod\left(K_{i t}, X_{i t}\right)$ denote the maximized operating profits of firm i at time t. The

\footnotetext{
${ }^{4}$ Other studies, e.g., Fama and Frech (2014) obtain similar results, however, offer a different explanation.
} 
profit function depends on capital, $K_{i t}$, and a vector of exogenous aggregate and firm specific shocks, $X_{i t}$. We assume that the firm i has a Cobb-Douglas production function, however, no longer with a constant returns to scale. End-ofperiod capital equals investment plus beginning-of-period capital net of depreciation: $K_{i t+1}=I_{i t}+\left(1-\delta_{i t}\right) K_{i t}$, in which capital depreciates at an exogenous proportional rate of $\delta_{i t}$. Firm incur adjustment costs when investing. We use a standard quadratic adjustment cost: $\Phi\left(I_{i t}, K_{i t}\right)=\left(\frac{a}{2}\right)\left(\frac{I_{i t}}{K_{i t}}\right)^{2} K_{i t}$ in which $a>0$.

One-period debt is used to finance investment. Specifically, at the beginning of time $t$, firm $i$ can issue an amount of debt, $B_{i t+1}$ (which must be repaid at the beginning of period $t+1$ ). In the meantime, firms pay back the bond, $B_{i t}$. The gross return on the bond is $r_{i t}^{B}$. For simplicity, assume the corporate tax rate to be zero. The payout of firm $i$ equals:

$$
D_{i t}=\Pi\left(K_{i t}, X_{i t}\right)-\Phi\left(I_{i t}, K_{i t}\right)-I_{i t}+B_{i t+1}-r_{i t}^{B} B_{i t}
$$

Let $M_{t+1}$ be the stochastic discount factor from $t$ to $t+1$. Firm $i$ maximizes its cum-dividend market value of equity:

$$
V_{i t}=\max _{I_{i t+s}, K_{i t+s+1}, B_{i t+s+1}} E_{t}\left[\sum_{i=0}^{\infty} M_{t+s} D_{i t+s}\right]
$$

It can be shown that the optimal condition in terms of equityholder value maximization is the following:

$$
E\left(r_{i t+1}^{I}\right)=\frac{\pi_{1}\left(K_{i, t+1}, X_{i, t+1}\right)}{1+a\left(I_{i t} / K_{i t}\right)}+\left(1-\delta_{i}\right)
$$

where $r_{i t+1}^{I}$ is the investment return of firm $i$ from $t$ to $t+1 . \pi_{1}\left(K_{i, t+1}, X_{i, t+1}\right)=$ $\frac{\partial \Pi\left(K_{i t+1}, X_{i t+1}\right)}{\partial K_{i t+1}}-\frac{\partial \Phi\left(K_{i t+1}, X_{i t+1}\right)}{\partial K_{i t+1}}$.

The expected investment return in equation (3) is the ratio of marginal benefit of investment at time $t+1$ to the gross corporate investment rate at time $t$. In 
equilibrium, the firm's investment return should equate the marginal cost of capital of debt. When bond investors are marginal investors, expected investment returns equate cost of debt capital, $E\left(r_{i t+1}^{B}\right)$,

$$
E\left(r_{i t+1}^{I}\right)=E\left(r_{i t+1}^{B}\right)
$$

Jointly considering the above two equations, we expect bond expected returns, $E\left(r_{i t+1}^{B}\right)$, to be inversely related to corporate investment, $\frac{i_{i t}}{k_{i t}}$, holding the benefit of investment constant. ${ }^{5}$ All the securities are rationally priced under the optimal investment perspective. Using the conventional proxy for $E\left(r_{i t+1}^{B}\right)$, bond yield, $y_{i t}$, we have

$$
y(i t)=\frac{\pi_{1}\left(K_{i, t+1}, X_{i, t+1}\right)}{1+a\left(I_{i t} / K_{i t}\right)}+\left(1-\delta_{i}\right)
$$

This leads to our first hypothesis:

H1. Holding expected cash flow constant, corporate asset growth is negatively associated with bond yields.

The agency problem explanation predicts that firms grow more than the optimal level. Controlling firm growth opportunities stay constant, high asset growth firms potentially have a high cost of capital.

H2. For high asset growth firms, bond yields could positively associated with asset growth rates.

The agency problem are prevalent in an environment with a great deal of information asymmetry. Investors could potentially over-, under-, or appropriately react to the potential managerial over-investment incentives. The second hypothesis is related to bond yield changes in the year after the asset growth measurement year. If investors over-react to the managerial incentive, we would see bond yields

\footnotetext{
${ }^{5}$ Under the assumption of non constant return to scale, the unit productivity of new investments, $I_{t}$ differs from that of existing assets, $K_{t}$.
} 
drop for high asset growth firms after the asset growth years. If bond investors are fully aware of issuers' incentives, we would see that bond yields stay constant after the asset growth year. Finally, as pointed out by Lakonishok, Shleifer, and Vishny (1994), investors may excessively extrapolate from firms' past growth when they value stocks. When investors cannot see through issuers' incentive, we may observe the yields of bonds issued by high-asset growth firms significantly drop in years afterwards. In case that investors do not fully understand the agency problem of over-investment, they may overvalue a firm with large investments by overvaluing its potential future cash flows. The lower return subsequent to large investment hence reflects a market correction of the initial overvaluation. The hypothesis is as below:

H3. For high asset growth firms, bond yields increase in the year after the high asset growth year.

There is a consistent expectation on the relationship between asset growth

rates and bond performance. We state the hypothesis alternatively in terms of bond performance.

H3A. High growth firms experience bad bond performance in the year after the high asset growth year.

\section{Data and Summary Statistics 3.1 Data}

The data used in this study come from several sources. First, the main transaction data of the US corporate bond market are obtained from the Trade Reporting and Compliance Engine (TRACE) database. Introduced in July 1, 2002, TRACE provides information on secondary market transactions, including transaction prices, volumes, trade direction and the exact data and time of the trade. We account for reporting errors using standard filtering procedures commonly used 
for the TRACE transaction data (see, Dick-Nielsen, 2014) ) ${ }^{6}$. Similar to Lin, Wang and $\mathrm{Wu}$ (2011), we also extend the sample to January 1994 using the data from the National Association of Insurance Commissioners (NAIC) database. The NAIC database consists of all transactions of publicly traded corporate bonds beginning in January 1994 by life insurance companies, property and casualty insurance companies, and health maintenance organizations (HMOs). Following Bessembinder, Kahle, Maxwell and Xu (2009), we compute daily bond yield by weighting each trade by its size. This approach puts more weight on the institutional trades that incur lower transaction cost and should more accurately reflect the underlying price of the bond. The month-end transaction is the last available daily price from the last five trading days of the month ${ }^{7}$. To determine the yield spread, we obtain the benchmark treasury rates from Federal Reserve Board. Then we follow Gurkaynak, Sack and Wright (2007) and employ a parametric model to estimate yield curve. The yield curve allows two humps, one at short maturities and the other at long maturities. Yield spread is then defined as the difference between the bond yield and the associated yield of the treasury yield curve at the same maturity. The sample period is from January 1994 to December 2014.

We obtain the bond characteristic data from Fixed Income Securities Database (FISD). This database contains bond issue- and issuer-specific variables such as issue amount, maturity, provisions, coupon and credit ratings on all U.S. corporate bonds maturing in 1990 or later. We merge our transaction data with bond characteristics and eliminate preferred shares, non-U.S. dollar denominated bonds, bonds with odd frequency of coupon payment, and bonds that are mortgage backed, asset

\footnotetext{
${ }^{6}$ These include (i) same-day trade corrections and cancellations; (ii) trade reversals which refer to corrections and cancellations conducted not on the trading day but thereafter; (iii) agency and interdealer transactions.

${ }^{7}$ Using the last transaction within the last five trading days of the month instead of that on the last day helps increase the number of non-missing monthly observations. If there are no trades in the last five trading days, the month-end price is missing for that month.
} 
backed or part of unit deals. To prevent the confounding effects of embedded options, we also exclude the callable, puttable, convertible, and sinking fund bonds, as well as bonds with a floater. Finally, we mainly use the Moodys rating from the FISD, but, if it is not available, we use the Standard \& Poors (S\&P) rating when possible and drop bonds whose ratings we cannot identify.

Moreover, we get the financial statements of firms from the Compustat. The firms are required to have positive total assets. To mitigate the backfilling biases, a firm must be listed on the Compustat for 2 years before it is included in the data set (e.g., Fama and French (1993)). We further exclude regulated, financial, or public service firms. The main variable of interest is the asset growth rate (AG). Following Cooper et al. (2008), the annual firm asset growth rate (AG) for year $\mathrm{t}$ is calculated as the percentage change in total assets (Compustat data item 6) from the fiscal year ending in calendar year t-2 to fiscal year ending in calendar year t-1:

$$
A G_{t}=\frac{\text { Total Assets }_{t-1}-\text { Total Assets }_{t-2}}{\text { Total Assets }_{t-2}}
$$

To compute asset growth rate, we require a firm not have zero or negative total assets in both years t-2 and t-1. We further winsorize asset growth rate at the top and bottom $1 \%$ in each year to control for the influence of outliers. The equity volatility is estimated using 252 daily return from the CRSP. Finally, we combine firm accounting information with bond transaction and FISD bond characteristic data using issuer 6-digit cusip. In the final sample, we have 447,543 month-end bond transactions of 8,909 bonds of 1,551 firms from January 1994 to December 2014.

\subsection{Summary Statistics}

Panel A of Table 1 provides the distribution of the main variables used in the analysis. Firm characteristics variables include asset growth (AG), total assets (in 
billion dollars), book leverage, pretax interest coverage (PIC), long-term debt to assets (LTA), total debt to capitalization (DTC), operating income to sales (OIS), net income to equity (ROE), and standard deviation of excess daily stock return (Sdret). Bond characteristics variables include yield, yield spread (YldSpread), amount issued (in million dollars), coupon, rating, and maturity. The variables' descriptions are provided in the Appendix. Firm specific variables are estimated at bond issuer level, while bond characteristics variables are estimated at bond issue level. The mean (median) asset growth is 0.10 (0.05) with the standard deviation of 0.25 . The average asset growth rate is smaller than that reported in Cooper et al. (2008) because in our sample, we consider firms with public debt issues. These firms are large in size and have relatively stable growth rates. Bond yield (yield spread) ranges from 2.59 (0.44) in the 5th percentile to 12.47 (9.93) in the 95th percentile. The average bond yield is $6.3 \%$ while the average of yield spread is $2.09 \%$. Credit rating is a widely used measure of corporate bond risk. We obtain the Moody's and the Standard and Poor's ratings and convert ratings into a numeric scale from 1 to 22: $22=$ Aaa, $21=\mathrm{Aa} 1(\mathrm{AA}+), 20=\mathrm{Aa} 2(\mathrm{AA}), \ldots, 2$ $=\mathrm{C}, 1=\mathrm{D}$. Ratings 13 through 22 (Baa3 through Aaa) are investment grade and ratings below 13 are non-investment grade. Bond ratings on average are 14.72, suggesting a Baa1 rating (investment grade rating). Bond maturities are around 11 years on average.

Panel B of Table 1 presents the correlation matrix among these variables. Asset growth is negatively associated with yield and yield spread. High asset growth firms have lower yield and yield spread. In addition, yield and yield spread are highly correlated. Liquidity, credit ratings, leverage, LTA, debts/cap, Sdret are positively related to yield and yield spread. However, we also note that credit ratings,PIC,income/sales and ROE are negatively associated with yield (yield spread). 
Overall, high asset growth firms are larger in size, higher in profitability, and lower in liabilities. Yield (yield spread) is positively related to liquidity, leverage ratios and equity volatility and negatively related to credit rating and profitability ratios.

Our sample is sorted into deciles based on their year to year annual asset growth rates (AG). Panel A of Table 2 shows bond issuer characteristics of asset growth decile portfolios. The high asset growth portfolio (Decile 10) contains bond issuers with the highest asset growth rate and the time-series average of value-weighted cross-sectional means of growth rates for these firms is substantial at $62 \%$. Decile 1 issuers are low asset growth firms, with average annual growth rates of $-19 \%$. Low asset growth firms tend to be firms that have low profitability ratios (OIS and ROE), low interest coverage rate, high leverage and high equity volatility. The high asset growth firms are the smallest firms in our sample with the yearly average of $\$ 42.9$ billion, but have the highest operating income to sales. D7 tends to be the firms with the largest size. Panel B shows the bond specific characteristics. Decile 1 has the largest yield spread with the average rating of 12.8. Decile 6,7 , and 8 contain bonds with the lowest yield spread and highest credit rating. The yield spread of D10 is 2.15 with the rating of 13.66 .

\section{Empirical Results}

In this section we conduct a series of empirical tests to investigate the potential driving sources of the asset growth effect. Asset growth effect has been well documented in the equity market. However, the drivers of asset growth have been largely ignored in this existing literature. First, we ask how does a firm finance their growth opportunities. To answer this question, we decompose asset growth and look at the subcomponents of asset growth from the financing side. Second, we examine the determinants of asset growth. To do that, we perform several portfolio sorts and conduct regression analysis. Next, we examine the asset growth effect 
on yield spread changes following the asset growth formation year. We further decompose asset growth into its major components from both the investing side and financing side of the balance sheet and ask whether the asset growth effect can be explained by the subcomponents of asset growth. Lastly, we explore whether asset growth can forecast excess corporate bond return.

\subsection{Asset Growth Decomposition}

Total asset growth captures the aggregate growth of a firm. To explore the potential driving sources of asset growth, we break down asset growth of various components with the emphasis of financing side. Following Cooper et al. (2008), the asset growth financing decomposition is as follows:

$$
\begin{aligned}
\text { Total asset growth }(A G) & =\text { Operating liabilities growth }(\Delta O p L i a b) \\
& + \text { Retained earnings growth }(\Delta R E) \\
& + \text { Stock financing growth }(\Delta S t o c k) \\
& + \text { Debt financing growth }(\Delta D e b t) \\
& + \text { Others financing growth }(\Delta O t h L S)
\end{aligned}
$$

Operating liabilities are defined as Compustat data item 181 minus debt financing, i.e. non-debt financing component of total liabilities. Retained earnings is Compustat data item 36 and is considered as the source of internal financing. Stock financing is defined as Compustat data item 130 plus Compustat data item 60 plus Compustat data item 38 less Compustat data item 36. Debt financing is Compustat data item 9 plus Compustat data item 34. Stock and debt are the main tools for external financing. Other liabilities and shareholders' equity are defined as total assets less all the above asset categories. All asset growth components are changes in these variables from the fiscal year ending in calendar year t-2 to the fiscal year ending in calendar year t-1 scaled by total assets in the fiscal year 
ending in calendar year t-2.

In Table 3, we report the growth of various asset growth components in each asset growth decile portfolio from the financing side. The number in each cell reports time-series average of yearly means of asset growth component variables from fiscal year t-2 to year t-1 scaled by total asset in the fiscal year ending in calendar year t-2. We sort the sample into deciles each year based on annual asset growth rate at the beginning of year t. There are several notable observations. First, growth in debts accounts for large fraction of asset growth from the financing side. Specifically, for the high asset growth decile, growth in debts contributes $62.9 \%(38.9 \% / 62.4 \%)$ of the total asset growth for the value-weighted portfolio. In the last three columns, we show the contribution of each financing component (RE, Equity and Debt) to the total financing activities, including both internal and external financing. For example, debt financing accounts for $79 \%$ of total financing activities, while equity financing takes about 13\%. This suggests that corporates highly rely on debt as the major tool to finance their growth opportunities. Second, the average growth in stock is $-0.2 \%$. More than $70 \%$ firms in our sample have negative growth in stock. This is consistent with pecking order theory and suggests that equity financing is not the main source for external financing. According to the first two observations, asset growth firms are more likely to rely on debt financing than on equity financing for asset growth, especially for high asset growth firms. More interestingly, we find that negative growth firms tend to be firms with negative changes in retained earnings and debt. We also note that for decile 5, 6 and 7 , these firms tend to buy back their equities by using retained earnings or debt.

The asset growth decomposition provides insights on the driving sources of asset growth. High asset growth firms are more likely to use debt to finance their 
investments, while negative asset growth firms have negative retained earnings and reduced amount of debt. The overall message is that corporates heavily rely on debt for external financing. Therefore, bond yield is considered as a good proxy for a firm's marginal cost of capital, which indicates an alternative way to re-examine the q-theory explanation by relating bond performance and asset growth firms.

\subsection{Determinants of the asset growth}

Q-theory of investment relates corporate investment to their cost of capital. Hou, Xue and Zhang (2015) suggest that lower cost of capital and better investment opportunity imply high marginal $\mathrm{q}$ and high corporate investment. According to the conjecture based on q-theory of investment, asset growth is negatively related to the cost of capital given expected profitability or cash flows. In other words, firms are more likely to grow when their cost of capital is low. In contrast, agency theory suggests that corporate managers have the over-investment and empirebuilding tendency. Thus, corporates might grow aggressively even when the cost of capital is high. In this section, we differentiate these two hypotheses by examining the determinants of the asset growth.

First, we explore the relationship between yield spread and asset growth using portfolio analysis. We calculate value-weighted yield spread and credit rating at bond-issuer level. Then we sort bond issuers into quintiles each year based on the yield spread at the beginning of the asset growth year. Results are provided in Table 4, where the reported asset growth rate is the time series average of crosssectional means. The cross-sectional means are calculated using value weight. D1 has the lowest yield spread, while D10 has the highest yield spread. In column 1, we show an inverse U-shaped relation between asset growth rate and yield spread. D4 group has the highest asset growth rate. As suggested in Cooper et. al (2008), the current asset growth rate is highly related to prior asset growth rate. To 
control for that, we conduct two-way sorts based on prior year asset growth rate and lagged yield spread. Our findings confirm the inverse-U shaped relation. The only exception is AG 2, which shows a negative relation between yield spread and asset growth rate.

Next, we sort issuers into deciles based on annual asset growth rate in each year and look at yield spread prior to the asset growth formation period. Moreover, we create a no growth portfolio as the benchmark by sorting bond issuers into deciles based on the absolute value of asset growth rate. We define the lowest decile as the no asset growth portfolio. Table 4 reports the results, in which the reported yield spread is the time series average of value-weighted cross-sectional means.

In Panel A, the first column reports average yield spreads of bond issuers on asset growth-sorted deciles. Interestingly, we find a U-shaped relationship between asset growth and yield spread. D1 has the highest yield spread of 3.98. This is consistent with the conjecture of q-theory investment that firms tend to have low growth rates when yield spread is high. Bond issuers tend to have lower yield spreads as asset growth rate increases and reaches the lowest point of 1.59 for D7. However, yield spreads of D9 and D10 are 1.76 and 2.59, respectively. The difference between D10 and D1 is -1.39 and is significant at $1 \%$ level $(\mathrm{t}=-10.23)$. We also note that the difference between D10-nogrowth is $0.46(t=4.87)$, suggesting that high asset growth decile has a relatively higher yield spread than that of no growth or medium growth portfolios.

To control for the profitability effect, we conduct two-way sorts based on asset growth rates and lagged ROE. We first sort the sample into three ROE groups (low, medium and high). Within each ROE groups, bond issuers are further sorted into asset growth decile portfolios. Results are presented from column 2 to column 4. Consistent with the previous findings, a U-shaped pattern remains across the 
asset growth portfolios within each ROE group. The difference between D10 and no growth portfolio is $0.38(\mathrm{t}=5.32)$ and $0.69(\mathrm{t}=3.33)$ for medium ROE group and high ROE group, respectively.

Following the above procedure, we also examine the asset growth and yield spread relation in rating based subsamples. Specifically, bond issuers are first sorted into quintiles (Q1 to Q5) based on the lagged rating. Q1 firms are rated of B1 or lower; Q2 are rated between Ba3 and Ba1; Q3 are rated between Baa3 and Baa1; Q4 are rated between A3 to A1; Q5 firms receive the highest rating with Aa3 or higher. Within each rating group, bonds issuers are further sorted into asset growth deciles. Again, we confirm a distinct U-shaped of each rating group. The difference between D10 and no growth portfolio is positive, but less significant.

In Panel $\mathrm{B}$, we focus on firms with newly issued bonds during asset growth formation period. The offering yield of new bonds is considered as the marginal cost of capital. We repeat the same process and sort bonds into asset growth deciles. The results are strong and consistent with our findings in Panel A. Overall, high asset growth firms are not the firms with the lowest yield spread. Instead, they tend to have higher yield spread. The difference between D10 and no growth portfolio is $0.4(\mathrm{t}=3.53)$ for all newly issued bonds.

Furthermore, we use regression analysis to examine the relation between yield spread and asset growth rate. According to prior studies, we control for both firm and bond characteristics that have been shown to be associated with firm asset growth: prior year asset growth, ROE, total assets, and leverage. We also include bond characteristics such as years to maturity and credit rating. The definitions of these variables are provided in appendix. The model is specified as follows: 


$$
\begin{aligned}
A G_{i, t} & =\alpha_{0}+\beta_{1} X_{i, t-1}+\beta_{2} A G_{i, t-1}+\beta_{3} R_{O} E_{i, t-1}+\beta_{4} \log (\text { Assets })_{i, t-1} \\
& +\beta_{5} \text { Leverage }_{i, t-1}+\beta_{6} \text { Maturity }_{i, t-1}+\beta_{7} \text { Credit Rating } \text { Red }_{i, 1}+\epsilon_{i, t-1}
\end{aligned}
$$

where the subscript $i, t$ refers to bond issuer $\mathrm{i}$ and year $\mathrm{t} . \mathrm{X}$ is the main variables, representing yield spread or bond yield of firm i. AG is bond issuers annual asset growth rate of year t. We include the lagged-year control variables in the regressions. We also consider firm-fixed effects to capture time-invariant heterogeneity across firms, and standard errors to account for clustering at the firm level. In addition, we include year fixed effects to capture the aggregate time-series trends.

We perform panel regressions and present the results in Table 6. First, we examine various model specifications from column 1 to column 5 . In column 1 , we only include yield spread as independent variable and the coefficient of yield spread is $-1.0626(\mathrm{t}=-8.22)$. To capture the U-shaped effect as we document in the previous section, we include the squared term of yield spread in the regression. We find the coefficient on yield spread is significantly negative and the coefficient of the quadratic term is significantly positive, suggesting a U-shaped relation between yield spread and asset growth rate. In column 3, we examine how firm characteristics affect firm asset growth rate. As expected, current asset growth rate is positive related to the prior year growth rate with the coefficient of $0.0293(t=2.49)$. The coefficient of ROE is $0.017(\mathrm{t}=2.93)$, suggesting that firms with more profits are more likely to grow. Moreover, leverage and firm size are negatively related to firm asset growth. In column 4, we include both yield spread and firm characteristics variables. In column 5, we also add bond characteristics (years to maturity and credit rating). In addition, we show that firms with higher ratings are associated with higher growth rate. The most telling story is that the coefficients on the squared yield spread term are positive and statistically significant across various 
model specifications. In the last column, we use the bond yield as an alternative measure of cost of capital. Because when firms raise capital, their decisions are based on both the level of capital and risk premium (yield spread). The coefficient on the quadratic term of yield is $5.85(\mathrm{t}=6.03)$, which is consistent with our findings using yield spread as the proxy of cost of capital.

Overall, our findings document a U-shaped relation between yield spread and firm asset growth. The U-shape relation holds when we control for both bond and firm specific characteristics. Our evidence is not consistent with the hypothesis based on the q-theory of investment. Instead, the potential driving sources of asset growth are more likely due to agency based explanation. In the next section, we examine the asset growth effect on yield spread changes.

\subsection{Asset Growth Effects on Yield Spread Changes}

According to the second hypothesis, the agency problem posits a positive relationship between asset growth and yield spread changes. To test H2, we explore the relation between asset growth and yield spread changes using portfolio analysis. We sort bond issuers into deciles based on asset growth rate in each year and estimate the yearly average yield spread changes from July of the asset growth year $t$ to July of year $t+1$. D1 has the lowest asset growth rate, while D10 has the highest. Table 7 reports the results, in which the reported average is the time-series average of cross-sectional means of the yield spread. The cross-sectional means are calculated using value-weight.

In Panel A, we show average yield spread changes for all the bonds in our sample. D1 has negative yield spread changes of $-8.5 \mathrm{bps}(\mathrm{t}=-3.22)$, while D10 has positive yield spread changes of $11 \mathrm{bps}(\mathrm{t}=3.7)$. More interestingly, we note that yield spread changes are statistically insignificant for D3 to D7 deciles. According to agency theory based hypothesis, the agency problem might be more pronounced 
when the asset growth is positive. Thus, we further divide our sample into positive and negative asset growth sample. Further, we sort bond issuers into deciles within each positive and negative asset growth group.

In the positive asset growth sample, we find that bonds issued by high asset growth firms tend to have positive yield spread changes. For example, yield spread changes are 8.1 bps $(t=3.38)$ and $10.2 \mathrm{bps}(\mathrm{t}=2.58)$ for D9 and D10, respectively. Yield spread changes are positive, but insignificant in other asset growth portfolios. In the negative asset growth sample, we show that bonds with more negative asset growth rate are associated with negative yield spread changes. Our evidence is consistent with $\mathrm{H} 2$ that bonds issued by high asset growth firms tend to have positive yield spread changes, while bonds issued by low or negative growth bonds tend to have negative yield spread changes.

In panel $\mathrm{B}$, we repeat the same process, but focus on the newly issued bonds. We use the yield spreads of the first available trade after issuance for the current period. We use yield spread in July of the following year as the next period. If there is no trade in July, we use the next available trade. We confirm our previous findings and show that asset growth is positive related to yield spread changes. The magnitude and statistical significance of yield spread changes are smaller in the newly issued sample.

Next, We conduct regression tests to study whether asset growth is a determinant of yield spread changes. We include a list of independent variables used in Collin-Dufresne et al. (2001), Campbell and Taksler (2003), and Chen et al. (2007). Specifically, we consider credit rating and liquidity. Liquidity is estimated by the Amihud illiquidity ratio. We expect positive changes in liquidity to have positive effect on yield changes. We also include four accounting variables: pretax interest coverage, operating income to sales, long-term debt to assets, and total 
debt to capitalization. Positive changes of the first two variables indicate financially healthy firms and are likely to produce a low yield spread. Positive changes of the second two variables indicate highly levered firms and imply a high yield spread. We also compute the standard deviation of daily excess returns for each bond issuer's equity over the 252 days during the asset growth period. We expect the positive change in the standard deviation of daily excess returns to have a positive effect on yield spreads. To control for macroeconomic variables, we use 1-year treasury rate, the difference between the 10- and 2- year Treasury rates, and the difference between the 30-day Euro-dollar and Treasury yields. The model is specified as follows:

$$
\begin{aligned}
\Delta\left({\text { YieldSpread })_{i, j, t+1}}\right. & =\alpha_{0}+\beta_{1}(\text { Asset Growth })_{i, t}+\beta_{2}\left(\text { Credit Rating }_{i, j, t}\right. \\
& +\beta_{3} \Delta(\text { Liquidity })_{i, j, t}+\beta_{4} \Delta \sigma E_{i, t} \\
& +\beta_{5} \Delta(\text { PreTax Interest Coverage })_{i, t} \\
& +\beta_{6} \Delta(\text { Operating Income } / \text { Sales })_{i, t} \\
& +\beta_{7} \Delta(\text { Debt/Assets })_{i, t}+\beta_{8} \Delta(\text { Debt } / \text { Capitalization })_{i, t} \\
& +\beta_{9}(1 y r \text { Treasury Rate })_{t} \\
& +\beta_{1} 0 \Delta(10 y r-2 y r \text { Treasury Rate })_{t} \\
& +\beta_{11} \Delta(30 \text { Day EuroDollar Rate })_{t}+\epsilon_{i, j, t}
\end{aligned}
$$

where the subscript $i, j, t$ refers to bond $\mathrm{j}$ of firm $\mathrm{i}$ at year $\mathrm{t}, \Delta$ represents the first difference in each variable for each bond $\mathrm{j}$, asset growth is defined as the year to year annual changes.

Table 8 reports panel regression results of the full sample and newly issued bonds over the sample period from 1994 to 2014 period. First, we examine various regression specifications. In column 1, we only include asset growth rate. The coefficient of asset growth rate is $0.459(\mathrm{t}=4.88)$, suggesting that one percent incre- 
ment of asset growth results in an 0.459 percent increase in yield spread change. In column 2, we additionally include four accounting variables. The coefficient of the asset growth rate is still significantly positive (0.3039, $\mathrm{t}=3.55)$. As expected, high income to sales is associated with a significant decrease in the yield spread, while higher leverage and higher equity volatility can lead to higher yield spread changes. In column 3, we include firm specific, bond specific and macroeconomic variables. The coefficients on asset growth remain significantly positive. One percent change in asset growth is associated with 0.3 percent change increase in yield spread. In addition, the deterioration of bond quality (rating) is related to a significant increase in the yield spread. Similarly, a higher risk in liquidity leads to an increase in the yield spread. This is consistent with the findings from Chen et al. (2007). Furthermore, based on the unique feature of asset growth, we divide the sample into two subsamples: positive AG and negative AG subsamples. The coefficients on the asset growth are significantly positive. For instance, the coefficients on the asset growth are $0.2276(\mathrm{t}=2.87)$ for positive AG subsample and $1.7645(\mathrm{t}=2.61)$ for negative AG subsample.

Columns 6 through 8 show the results using the newly issued bonds for the full sample and two subsamples. The results are similar to those using all the traded bonds. One percent increase in asset growth is associated with 0.24 percent increase in yield spread changes for newly issued bonds. The asset growth growth effects are 0.26 and 1.67 for positive asset growth sample and negative asset growth sample, respectively. Overall, the result in Table 8 shows that asset growth is significantly and positively associated with yield spread changes regardless of whether we include firm-specific, bond-specific, or macro-level variables in different sample settings. Economically, a one percent increase in asset growth results in a 0.29 basis point increase in yield spread. For positive and negative asset growth firms, 
one percent increase in asset growth indicates a 0.228 and 1.76 basis point increase.

We also conduct robustness checks by examining the asset growth effect through various sample periods: i) pre-crisis, ii) crisis, and iii) post-crisis. During the recent financial crisis period, firms tend to have low asset growth rate due to the bad market conditions. Corporate managers face financial constraints and are cautious in how they invest. Thus, we expect that the firms tend to have less over-investment tendency during the crisis. In the meantime, investors are more rational and tend to make safe investments.

Following the NBER, the recent financial crisis is defined from December 2007 to June 2009. We define our sample before 2008 as the pre-crisis period, 2008 and 2009 as the crisis period, and after 2009 as the post crisis period. We repeat the regressions in Table 8 and test for asset growth effect in different sample periods. The results are reported in Table 9 . Panel A of Table 9 considers the sample of all bonds while Panel B represents the results for the newly issued bonds. We find that the coefficients on asset growth for the full sample are significantly positive in precrisis period and post crisis period while significantly negative in the crisis period. This is consistent with our conjecture. The coefficient of asset growth is $-1.64(\mathrm{t}=-$ 3.32), suggesting that asset growth is associated with lower yield spread changes. Facing higher cost of capital and more financial constrains, agency problem tends to be less pronounced. When we divide the full sample bonds into two subsamples based on the asset growth rate, we find that the coefficients on asset growth are significantly positive except for the negative AG subsample in the pre-crisis period. In Panel B, the results on the asset growth are similar except that the coefficients on the asset growth are significantly negative for both positive AG and negative AG subsamples. Overall, the results suggest that the asset growth is positively associated with the yield spread change in pre-crisis and post crisis period while 
negatively associated with the yield spread during the crisis period.

Furthermore, we examine the asset growth effect on both investment and speculative bonds. Since bonds performance varies across various rating groups, we ask whether the asset growth effect holds in investment and speculative grade bonds. Similarly, we repeat the regressions in Table 8 for the bonds in two different rating groups respectively and report the results in Table 10. Panel A of Table 10 considers the full sample bonds while Panel B represents the results for the newly issued bonds. As we expect, the coefficients on the asset growth are significantly positive for investment-grade and speculative grade bonds. They stay significantly positive for the full sample and two asset growth subsample bonds. However, when we look at the regressions for investment-grade and speculative bonds using newly issued bonds, the coefficients on the asset growth become insignificant for the negative AG subsample bonds. Overall, all the results consistently show that the asset growth is positively associated with the yield spread change. In the following section, to explore the driving sources of asset growth effect, we break down asset growth into major balance sheet components from investment and financing aspects.

\subsection{Asset Growth Effect: Decomposition Results Explanation}

As we have shown above, asset growth has a positive impact on future bond yield changes. Our findings are more consistent with predictions from the agency theory. In this section, we further explore the asset growth effect on bond yield changes by examining various subcomponents of asset growth. In addition, we examine whether the manner in which the growth is financed affects the yield changes. One might expect that agency problem is more pronounced when corporate managers make large investments in physical assets or new equities and less pronounced when firms invest in intangible assets or reserve more cash. Moreover, 
we expect that large expansion and rapid asset growth are more likely financed with external financing sources.

In addition to the asset growth decomposition from the financing side of balance sheet as specified in equation (7), we decompose asset growth into 6 subcomponents: cash growth, noncash current assets growth, property, plant and equipment (PPE) growth, investment and advances growth, intangible assets growth and other assets growth from the investment side. To maintain an asset growth identity, each asset category difference is scaled by the previous years total asset value.

We perform regressions of yield spread changes on the lagged components of asset growth. We report results of the full sample in Panel A of Table 9. From an asset investment standpoint, we find that increases in non-cash current assets, PPE, investment and advances, intangible assets and other assets are associated with significant positive coefficients. In particular, t-statistics for the coefficients on the significant investment components vary from 2.07 for PPE to 3.87 for investments and advances. When we include all six investment components of asset growth in the same regression, we find that changes in noncurrent assets, PPE and investment and advances are positively significant, with growth in noncurrent assets and investment and advances exhibiting strong effect (the t-statistics for the coefficients is 3.29 and 3.87 respectively). It suggests that when firms make large investments in noncurrent assets, PPE and investment and advances, yield spread increases after the asset growth period. In addition, changes in cash and others assets are negatively significant and the coefficient of changes in intangible assets are not statistically significant. Our findings are consistent with our conjecture. Corporate managers are more likely to expand in fixed assets, new equities or operating assets when they have the over-investment or empire building tendency, 
while agency costs would be lower when firms reserve more capital to meet their debt obligations. Another interesting finding is yield spread changes are unrelated to changes in intangible assets.

In equation (7), we decompose total asset growth into 5 components: operating liabilities growth, retained earnings growth, stock financing growth, debt financing growth and others shareholders equity and liabilities growth from the financing side. We find that growth in debt financing and operating liabilities growth are associated with positive yield spread changes. Specifically, growth in operating liabilities and debt are associated with the strongest effect with coefficient of $1.7(t=4.79)$ and $1.49(t=4.14)$, respectively. As shown in Table 2, growth in debts and growth in operating liabilities accounts for more than $60 \%$ and $20 \%$ of total asset growth, respectively, suggesting that corporates heavily rely on debts and operating liabilities when they grow rapidly. We show that the agency effects are more likely to occur when firms realize growth opportunities by financing with debts and operating liabilities. When we include all subcomponents of financing growth variables into the regression, both debts and operating liabilities growth variables are statistically significant, while growth in retained earnings and others are negatively insignificant. The agency costs would be lower when firms finance their investments using retained earnings.

We repeat the same process by examining the various growth components in positive asset growth sample and negative growth sample. Results of positive growth sample are reported in Panel B. From the investment standing point, growth in noncurrent assets and intangible assets are positive and significant; whereas growth in retained earnings and other assets are negative and significant. The intangible assets are still insignificant related to yield spread changes. From the financing side, it is worth noting that changes in both equity and debt 
financing are positively related to yield spread changes, suggesting that there are more pronounced agency problems when firms use external financing sources.

\subsection{Asset Growth and Bond Performance}

In the previous sections, we have shown that high firm asset growth rate is associated with high yield spread, suggesting that high asset growth is more likely due to the over-investment incentives of corporate managers. Moreover, asset growth is negatively correlated with future yield spread changes. As discussed in H3, biased investor belief can lead to mispricing of corporate bond. Overextrapolation of firm past growth realizations in the presence of agency problem can result in a sharp decline in bond values. In this section, we examine the asset growth effect on bond performance and ask whether asset growth can forecast excess corporate bond return.

Corporate bond return could be contaminated with mispricing. Due to the agency problems, firms tend to make large investments regardless of the cost of capital and growth opportunities. On the other hand, investors may not see through issuer's incentives. Greenwood and Hanson (2013) show that bond investors overextrapolate firms with high asset growth and their expectations will be revised after a period of relatively low asset growth, resulting in lower bond return. For example, investors tend to be too optimistic of the future growth opportunities of high asset growth firm and believe these firms will continue to grow rapidly. However, these firms tend to over grow in the past and exhaust potential growth opportunities, resulting in a relatively low asset growth in the following period. Thus, we expect that asset growth is negatively associated with future excess cor-

porate bond return. The annual corporate bond return as of year $\mathrm{t}+1, \operatorname{Ret}_{t+1}$, is computed as: 


$$
\operatorname{Ret}_{t+1}=\frac{P_{t+1}+C-P_{t}}{P_{t}}
$$

where $P_{t+1}$ is the bond price at year $\mathrm{t}+1$, which is defined as the bond price at the 18 month after the formation of asset growth portfolios; $\mathrm{C}$ is the annual coupon payment; $P_{t}$ is the bond price at year $\mathrm{t}$, which is defined as the bond price at the 6 month after the formation of asset growth portfolios.

Next, we express the above equation in terms of the log return: $r=\log (1+$ ret $)$. Bond return can be decomposed as:

$$
r_{t+1}=\log \left[\frac{P_{t}^{y_{t+1}}}{P_{t}}\left(1+y_{t+1}\right)\right]=\log \left(\frac{P_{t}^{y_{t+1}}}{P_{t}}\right)+\log \left(1+y_{t+1}\right)
$$

where $P_{t}^{y_{t+1}}$ is the bond price estimated with yield at year $\mathrm{t}+1$, all else being equal. The first term is the yield change effect component on bond return and the second term is the yield effect component on bond return. This is essentially similar to the decomposition in Campbell, Lo, and MacKinlay (1997), however, coupon bonds are used here. In the bond return decomposition, the firm term is analogous to bond price change, i.e. $P_{t+1} / P_{t}$. The second term is analogous to bond current yield, which is the ratio of annual coupon payment to the lagged bond price. Bond price at year $\mathrm{t}$ is obtained from TRACE. To estimate $P_{t}^{y_{t+1}}$, we use bond yield at year $\mathrm{t}+1$ and other bond characteristics from year $\mathrm{t}$.

We perform panel regression to examine the asset growth effect on future excess corporate bond return. The dependent variable is the return $\operatorname{Ret}_{i, t+1}$ of an individual bond $\mathrm{i}$ in excess of one year treasury rate at year $t+1$. We include firm specific variables: asset growth rate, leverage, operating income to sales and market to book $(\mathrm{M} / \mathrm{B})$ ratio. We also control for bond specific variables, such as bond ratings, years to maturity and yield to maturity. All independent variables are obtained at the end of the formation of asset growth portfolios. The model is 
specified as follows:

$$
\begin{aligned}
& \operatorname{Ret}_{i, j, t+1}-r_{f, t+1}=\alpha_{0}+\beta_{1}(\text { Asset Growth })_{i, t}+\beta_{2} \text { Leverage }_{i, t} \\
& +\beta_{3} \text { Operating Income/Sales }{ }_{i, t}+\beta_{4} M / B_{i, t} \\
& +\beta_{5} \text { Credit Rating }_{i, j, t}+\beta_{6} \text { Maturity }_{i, j, t}+\beta_{7} \text { Yield }_{i, j, t}+\epsilon_{i, j, t}
\end{aligned}
$$

Table 12 shows the panel regression results. In column 1 to column 4, the dependent variable is the excess return of corporate bonds over one year treasury rate. In column 5, the dependent variables is the yield change effect component of bond return. In column 6 , the dependent variable is the yield effect component of bond return. The most notable observation is negative relation between asset growth and excess corporate bond return across various model specifications. In column 1, we only include asset growth as independent variable. We further control for bond specific and firm specific variables for column 3 and 4 , respectively. In column 4, we control for both firm and bond specific variables. The coefficient on asset growth is $-0.023(\mathrm{t}=-3.41)$, suggesting that one percent increase in asset growth can forecast a $-0.023 \%$ drop in future bond return. In column 5 and 6 , we use yield change effect component and yield effect component as dependent variables, respectively. As we expect, the negative asset growth effect on bond return is mainly attributed to the yield change component. The coefficient on yield change component is negative and significant, while the coefficient on yield component is insignificant. In addition, our results also show that leverage and years to maturity are positively related to future bond return. Income to sales, $\mathrm{M} / \mathrm{B}$, rating and yield are negatively associated with future bond return. Overall, the findings of bond return analysis is consistent with our conjecture. 


\section{Conclusion}

In this paper, we empirically distinguish rational expectation and mispricingbased explanation on asset growth anomaly by using corporate bond data. First, we document a distinct U-shaped relation between yield spread and corporate asset growth. The pattern holds strong when we control for bond- and firmspecific characteristics using both portfolio and regression analysis. High asset growth firms tends to be firms with relatively higher yield spread. We suggest that asset growth is more likely due to the over-investment and empire building tendency. Second, we show a positive relation between asset growth and yield spread changes. High asset growth firms are more likely to have positive yield changes. The positive asset growth effect remains strong across various sample periods and rating groups. Our evidence is consistent with the conjecture of agency problem. In the asset growth decomposition, we find that agency problem is more significant when firms use debt and operating liabilities for financing and when firm make large investments in fixed assets and new equities. Finally, asset growth is positively associated with future bond return, which is attributed to the yield change effect component. Overall, our empirical finding is more aligned with the agency problem explanation of corporate asset growth. 


\section{References}

Anderson, C., and L. Garcia-Feijóo, 2006, Empirical evidence on capital investment, growth options, and security returns, Journal of Finance 61, 171-194.

Bessembinder, H., K. M. Kahle, W. F. Maxwell, and D. Xu, 2009, Measuring abnormal bond performance, Review of Financial Studies 22, 4219-58.

Black F and M. Scholes, 1973, The Pricing of Options and Corporate Liabilities. Journal of Political Economy 81, 637-54.

Brainard, W., and J. Tobin 1968, Pitfalls in financial model building, The American Economic Review, 58, 99-122.

Campbell, J. Y. and G. B. Taksler, 2003, Equity Volatility and Corporate Bond Yields, Journal of Finance 58, 2321-50.

Campbell, J. Y., A. W. Lo, and A. C. MacKinlay, 1997, The Econometrics of Financial Markets, Princeton University Press.

Campello, M., L. Chen and L. Zhang, 2008, Expected Returns, yield spreads, and asset pricing tests, Review of Financial Studies 21, 1297-1338.

Cochrane, J. H., 1991, Production-based asset pricing and the link between stock returns and economic fluctuations, Journal of Finance 46, 209-37.

Cochrane, J. H., 1996, A cross-sectional test of an investment-based asset pricing model, Journal of Political Economy 104, 572-621.

Collin-Dufresne, P., R. Goldstein, and S. Martin, 2001, The determinants of credit spread changes, Journal of Finance 56, 2177-2207.

Cooper, M., H. Gullen, and M. Schill, 2008, Asset Growth and the Cross-Section of Stock Returns, Journal of Finance 63, 1609-51.

Dick-Nielsen, J., 2009, Liquidity Biases in TRACE, emphJournal of Fixed Income $19,43-55$. 
Dick-Nielsen, J., 2014, How to clean Enhanced TRACE data, Unpublished working paper.

Fama, E. F., and K. R. French, 1993, Common Risk Factors in the Returns on Stocks and Bonds, Journal of Financial Economics 33, 3-56.

Fama, E.F., and K. R. French, 2015, A five-factor asset pricing model, Journal of Financial Economics, 116, 1-22.

Gebhardt, W. R., S. Hvidkjaer, and B. Swaminathan, 2005, The cross-section of expected corporate bond returns: Betas or characteristics? Journal of Financial Economics 75, 85-114.

Greenwood, R. and S. Hanson, 2013, Issuer Quality and Corporate Bond Returns, Review of Financial Studies 26, 1486-1525.

Greenwood, R. and A. Shleifer, 2014, Expectations of Returns and Expected Returns, Review of Financial Studies 27, 714-46.

Greenwood, R., S. Hanson and L. Jin, 2016, A moedel of credit market sentiment, HBS working paper.

Gurkaynak, R.S., B. Sack and J.H. Wright, 2007, The U.S. Treasury yield curve: 1961 to the present., Journal of Monetary Economics 54, 2291-2304.

Hayashi, F., 1982, Tobins marginal Q and average Q: A neoclassical interpretation, Econometrica 50, 215-224

Hou, K., C. Xue, and L. Zhang, 2015, Digesting anomalies: An investment approach, Review of Financial Studies 28, 650-705.

Jensen, M.C., and W. H. Meckling, 1976, Theory of the firm: Managerial behavior, agency costs and ownership structure, Journal of Financial Economics, 3, 305-360. 
Jensen, M. C., 1986, Agency costs of free cash flow, corporate finance, and takeovers, The American Economic Review, Vol. 76, No. 2, 323-329.

Kuehn, L. A. and L. Schmid, 2014, Investment-based corporate bond pricing, Journal of Finance 69, 2741-76.

Jostova, G., S. Nikolova, A. Philipov, and C. W. Stahel, 2013, Momentum in corporate Bond Returns, Review of Financial Studies 26, 1649-93.

Lakonishok, J., A. Shleifer and R. W. Vishny, 1994. Contrarian Investment, Extrapolation, and Risk, Journal of Finance 49, 1541-78.

Lam, F.E.C., and K.J. Wei, 2011, Limits-to-arbitrage, investment frictions, and the asset growth anomaly, Journal of Financial Economics 102, 127-49.

Li, X.N., D. Livdan, and L. Zhang, 2009, Anomalies, Review of Financial Studies $22,4301-34$.

Lin, H., J. Wang, and C. Wu, 2011, Liquidity Risk and Expected Corporate Bond Returns, Journal of Financial Economics 99, 628-650.

Lin X. and L. Zhang, 2013, The investment manifesto, Journal of Monetary Economics 60, 351-66.

Lipson, M.L., S. Mortal, M.J. Schill, 2011, On the scope and drivers of the asset growth effect, Journal of Financial and Quantitative Analysis 46, 1651-82.

Liu, X., T.M. Whited, and L. Zhang, 2009, Investment-based expected return, Journal of Political Economy 117, 1105-39.

Philippon, T., 2008. The bond market's Q, Quarterly Journal of Economics, 124, $1011-56$.

Pontiff, J. and A. Woodgate, 2008. Share issuance and cross-sectional returns, Journal of Finance 63, 921-45. 
Titman S., K. C. Wei and F. Xie, 2004, Capital Investments and Stock Returns, Journal of Financial and Quantitative Analysis 39, 677-700.

Tobin, J., 1969, A General Equilibrium Approach to Monetary Theory, Journal of Money, Credit and Banking, 1, 15-29.

Watanabe, A., Y. Xu, T. Yao and T. Yu, 2013, The Asset Growth Effect and Market Efficiency: Insights from International Stock Markets, Journal of Financial Economics 108, 529-63.

Yao, T., T. Yu, T. Zhang and S. Chen, 2011. Asset growth and stock returns: Evidence from Asian financial markets, Pacific-Basin Finance Journal 19, 115139.

Zhang, L., 2005, The Value Premium. Journal of Finance 60, 67-103. 


\section{Appendix}

The variables used in the paper are listed below (with Compustat data items in parenthesis).

Asset growth (AG) is the 1-year percentage change in total firm assets $\left[\left(\right.\right.$ Total Assets $_{t-1}-$ Total $_{\text {Assets }}$ t-2 $\left._{2}\right) /$ Assets $\left._{t-2}\right]$, where assets are Compustat data item 6 . To compute AG, a firm must have nonzero total asset in both year t-1 and $\mathrm{t}-2$.

Yield spreads are defined as the difference between the yield of bond and the associated yield of the Treasury curve at the same maturity. We employ a parametric model to estimate yield curve following Gurkaynak, Sack and Wright (2007). Pretax interest coverage is the ratio of [operating income after depreciation (data 178)+interest expense(data 15)] to interest expense.

Operating income to sales is [operating income before depreciation (data 13) to net sales (12).

Long-term debt to assets is [total long-term debt (data 9) to [total assets (data $6)]$.

Total debt to capitalization is [total long-term debt (data 9)+debt in current liabilities (data 34)+average short-term borrowings (data 104)] to [total liabilities (data 181)+market value of equity (from CRSP)].

$\log$ (Assets) is the natural log of total assets (data 6).

Leverage is the sum of long-term debt and debt in current liabilities, scaled by total assets [(long-term debt (data 9) + Debt in current liabilities(data 34)/total assets(data 6)].

ROE is net income (data 172) scaled by total shareholder's equity (data 144).

SDExret is the equity volatility, which is estimated using 252 daily excess stock returns (from CRSP), for each issuer. 
$10 \mathrm{Yr}$ is the 10-year treasury yield .

Treasury slope: we define the slope of the yield curve as the difference between 10-year and 2-year Treasury yield. We interpret this proxy as both an indication of expectation of future short rates, and as an indication of economic health.

Euro is the difference between the 30-day Eurodollar and 3-month Treasury Bill rate that controls for other potential liquidity effects on corporate bonds relative to Treasury bonds.

Amihud is Amihud illiquidity ratio estimated based on bond returns and trading volume at daily frequencies, for a given year. Specifically, Amihud $=\frac{1}{N} \sum_{j=1}^{N} \frac{R_{j}}{Q_{j}}$. $\mathrm{N}$ is the number of days with at least one trade on the bond during a year, and $R_{j}$ and $Q_{j}$ are the return and dollar trading volume on day $\mathrm{j}$ when there is at least a trade. The return $R_{j}$ is measured as the percentage change in closing clean price, from the most recent day with trading to the last trade on day $\mathrm{j}$. 


\section{Table 1: Summary Statistics}

Panel A of the table reports the distribution of the main variables used in the analysis. Firm characteristics variables include asset growth (AG), total assets (in billion \$), book leverage, pretax interest coverage (PIC), long-term debt to assets (LTA), total debt to capitalization (DTC), operating income to sales (OIS), net income to equity (ROE), and standard deviation of excess daily stock return (Sdret). Bond characteristics variables include yield, yield spread (YldSpread), Amihud measure (\%), amount issued (in million $\$$ ), coupon, rating, and maturity. We assign integer numbers to the credit ratings (i.e., Aaa=22, Aa1=2, .., $\mathrm{D}=1)$. The definitions of the variables are provided in the appendix. The distributional attributes include the 5th, 25th, 50th, 75th and 95th percentiles, as well as the mean and standard deviation (Std Dev) of each variable. We obtain each statistic each year and then take the average over time. Panel B of the table reports the correlation matrix of these variables. The sample period is from January 1994 to December 2014.

\begin{tabular}{lccccccc}
\hline \multicolumn{7}{c}{ Panel A: Summary Statistics } \\
\hline PG & P25 & Mean & Median & P75 & P95 & Std Dev \\
\hline Yield & -0.18 & 0.00 & 0.08 & 0.05 & 0.13 & 0.61 & 0.25 \\
Yield Spread & 2.59 & 3.93 & 6.36 & 5.85 & 7.96 & 12.47 & 2.63 \\
Ratings & 0.44 & 0.81 & 2.29 & 1.80 & 4.35 & 9.23 & 2.54 \\
Amihud (\%) & 7.74 & 12.82 & 14.72 & 15.11 & 17.33 & 19.92 & 3.61 \\
Amount Issued & 0.00 & 0.04 & 0.82 & 0.65 & 1.62 & 2.48 & 0.49 \\
Coupon & 167.4 & 302.7 & 678.6 & 495.7 & 841.6 & 1971.4 & 332.6 \\
Maturity & 4.39 & 5.72 & 6.78 & 6.69 & 7.72 & 9.48 & 1.59 \\
Assets & 2.10 & 4.99 & 10.97 & 7.87 & 13.77 & 28.67 & 8.01 \\
Leverage & 3.08 & 12.70 & 72.80 & 31.14 & 91.53 & 286.10 & 30.91 \\
PIC & 0.10 & 0.20 & 0.32 & 0.29 & 0.40 & 0.59 & 0.21 \\
LDA & 1.39 & 3.69 & 10.35 & 6.77 & 12.22 & 35.74 & 11.41 \\
DTC & 0.07 & 0.16 & 0.25 & 0.23 & 0.32 & 0.48 & 0.19 \\
OIS & 0.04 & 0.11 & 0.23 & 0.19 & 0.31 & 0.53 & 0.16 \\
ROE & 0.04 & 0.12 & 0.21 & 0.19 & 0.28 & 0.46 & 0.17 \\
Sdret & -0.18 & 0.06 & 0.16 & 0.14 & 0.22 & 0.55 & 0.38 \\
\hline
\end{tabular}

\begin{tabular}{|c|c|c|c|c|c|c|c|c|c|c|c|c|}
\hline \multicolumn{13}{|c|}{ Panel B: Correlation } \\
\hline & Yield & Yldspread & Ratings & Amihud & Assets & Leverage & PIC & LTD & DTC & OIS & ROE & Sdret \\
\hline $\mathrm{AG}$ & -0.0416 & -0.0855 & 0.0040 & -0.1074 & -0.0082 & -0.0112 & 0.0261 & -0.0063 & 0.0007 & 0.0118 & 0.0129 & -0.0082 \\
\hline Yield & & 0.8833 & -0.5184 & 0.3680 & -0.3253 & 0.3198 & -0.1176 & 0.2803 & 0.4546 & -0.2776 & -0.0616 & 0.4767 \\
\hline Yldspread & & & -0.6113 & 0.3324 & -0.3072 & 0.3401 & -0.1049 & 0.3188 & 0.4789 & -0.3079 & -0.0634 & 0.4796 \\
\hline Ratings & & & & -0.1129 & 0.5536 & -0.4622 & 0.1799 & -0.5110 & -0.6237 & 0.3668 & 0.0288 & -0.3551 \\
\hline Amihud & & & & & 0.1123 & 0.0165 & -0.0540 & -0.0180 & 0.1156 & -0.1366 & 0.0048 & 0.1187 \\
\hline Assets & & & & & & -0.3116 & 0.0866 & -0.3569 & -0.2779 & 0.0074 & 0.0100 & -0.2405 \\
\hline Leverage & & & & & & & -0.1778673 & 0.9375 & 0.7943 & -0.0601 & -0.0240 & 0.2030 \\
\hline PIC & & & & & & & & -0.1714 & -0.2164 & 0.2021 & 0.0067 & -0.0605 \\
\hline LTD & & & & & & & & & 0.7413 & -0.0570 & -0.0284 & 0.1776 \\
\hline DTC & & & & & & & & & & -0.3996 & -0.0361 & 0.3190 \\
\hline OIS & & & & & & & & & & & 0.0311 & -0.1945 \\
\hline ROE & & & & & & & & & & & & -0.0407 \\
\hline
\end{tabular}


Table 2: Asset Growth Deciles: Bond Issuer and Issue Characteristics

This table shows summary statistics of bond-issuer (Panel A) and bond-specific (Panel B) characteristics for the deciles based on the asset growth at the fiscal year t. D1 represents issuers with the lowest asset growth rate while D10 represents issuers with the highest asset growth rate. Issuer characteristics include assets (in billions \$), leverage, pretax interest coverage (PIC), long-term debt to assets (LDA), total debt to capitalization (DTC), operating income to sales (OIS), ROE and standard deviation of daily excess return (Sdret). We also include bond-specific characteristics, including yield, yield spread (YldSpread), credit rating, amihud measure, amount issued (in millions \$), maturity, and coupon rate. We assign integer numbers to the credit ratings (i.e., $\mathrm{Aaa}=22, \mathrm{Aa} 1=2, \ldots, \mathrm{D}=1$ ). Details on the construction of these variables are provided in the Appendix. The number in each cell reports time-series averages of yearly cross-sectional means over the full sample period (January 1994 to December 2014) across all bond issues and issuers.

\begin{tabular}{lccccccccc}
\hline \multicolumn{10}{c}{ Panel A. Bond Issuer Characteristics } \\
\hline Decile & AG & Assets & Leverage & PIC & LDA & DTC & OIS & ROE & Sdret \\
\hline D1 (low) & -0.18 & 50.1 & 0.35 & 4.82 & 0.29 & 0.26 & 0.17 & 0.09 & 2.31 \\
D2 & -0.06 & 47.6 & 0.33 & 6.99 & 0.28 & 0.24 & 0.19 & 0.10 & 1.88 \\
D3 & -0.02 & 48.2 & 0.30 & 8.00 & 0.25 & 0.22 & 0.20 & 0.12 & 1.81 \\
D4 & 0.01 & 75.7 & 0.33 & 7.11 & 0.27 & 0.23 & 0.22 & 0.12 & 1.68 \\
D5 & 0.03 & 45.7 & 0.31 & 10.12 & 0.25 & 0.20 & 0.21 & 0.20 & 1.68 \\
D6 & 0.06 & 89.2 & 0.33 & 9.47 & 0.25 & 0.25 & 0.20 & 0.14 & 1.64 \\
D7 & 0.09 & 76.5 & 0.30 & 13.42 & 0.22 & 0.20 & 0.21 & 0.19 & 1.59 \\
D8 & 0.13 & 46.6 & 0.27 & 14.60 & 0.21 & 0.16 & 0.21 & 0.18 & 1.63 \\
D9 & 0.22 & 51.8 & 0.28 & 16.51 & 0.23 & 0.18 & 0.24 & 0.18 & 1.82 \\
D10 (high) & 0.62 & 42.9 & 0.32 & 10.57 & 0.27 & 0.23 & 0.25 & 0.14 & 1.91 \\
\hline
\end{tabular}

\begin{tabular}{lccccccc}
\hline \multicolumn{7}{c}{ Panel B. Bond Issue Characteristics } \\
\hline Decile & Yield & YldSpread & Rating & Amihud (\%) & Amount Issued & Maturity & Coupon \\
\hline D1 (low) & 8.15 & 4.42 & 12.78 & 1.51 & 699.0 & 10.64 & 7.19 \\
D2 & 6.98 & 3.52 & 13.56 & 1.26 & 646.6 & 10.70 & 7.09 \\
D3 & 6.74 & 2.48 & 14.13 & 0.99 & 632.4 & 10.96 & 7.01 \\
D4 & 6.56 & 2.30 & 14.25 & 0.98 & 684.1 & 11.25 & 6.96 \\
D5 & 5.97 & 1.82 & 15.11 & 0.82 & 611.5 & 10.91 & 6.70 \\
D6 & 5.92 & 1.62 & 15.55 & 1.07 & 631.3 & 11.44 & 6.66 \\
D7 & 5.80 & 1.52 & 15.82 & 0.87 & 634.5 & 10.78 & 6.58 \\
D8 & 5.72 & 1.58 & 15.83 & 0.82 & 664.5 & 10.79 & 6.49 \\
D9 & 5.93 & 1.84 & 15.22 & 0.79 & 655.3 & 10.66 & 6.59 \\
D10 (high) & 6.46 & 2.15 & 13.66 & 0.65 & 677.8 & 10.64 & 6.81 \\
\hline
\end{tabular}


Table 3: Asset Growth Decomposition

Asset growth is decomposed into various components from the financing side of the balance sheet. The financing decomposition defines total assets as the sum of: (1) Retained earnings ( $\Delta$ RE: Compustat \#36), (2) Stock ( $\Delta$ Stock: Compustat \#130 + Compustat \#60 - Compustat \#36- Compustat \#88), (3) Debt ( $\Delta$ Debt: Compustat \#9 + Compustat \#34 + Compustat \#104), Operating liabilities ( $\Delta$ OpLiab: Compustat $\# 181$ - $\Delta$ Debt), (5) and other Liabilities and Shareholders' equity ( $\Delta$ OthLS: $\Delta$ Total assets- $\Delta$ RE- $\Delta$ Stock$\Delta$ Debt- $\Delta$ OpLiab). Asset growth decomposition variables are changes in these variables from the fiscal year ending in calendar year $\mathrm{t}-2$ to the fiscal year ending in calendar year $\mathrm{t}-1$ scaled by total assets in the fiscal year ending in calendar year t-2. Panel A reports time series average of value-weighted annual changes in these variables over the full sample period (January 1994 to December 2014) across all bond issuers. Panel B reports time series average of equal-weighted annual changes in these variables over the full sample period (January 1994 to December 2014) across all bond issuers.

\begin{tabular}{lcccccccccc}
\hline \multicolumn{10}{c}{ Panel A. Value-weighted Asset Growth Decomposition } \\
\hline Decile & $\mathrm{N}$ & AG & $\Delta$ RE & $\Delta$ Stock & $\Delta$ Debt & $\Delta$ OpLiab & $\Delta$ OthLS & RE & Stock & Debt \\
\hline All & 8584 & 0.0762 & 0.0158 & -0.002 & 0.0386 & 0.0275 & 0.0145 & 0.3015 & -0.0382 & 0.7366 \\
D1 & 848 & -0.1795 & -0.0818 & -0.0068 & -0.0523 & -0.0356 & -0.013 & 0.5806 & 0.0483 & 0.3712 \\
D2 & 860 & -0.0624 & -0.018 & -0.0093 & -0.0258 & -0.0093 & -0.0058 & 0.3390 & 0.1751 & 0.4859 \\
D3 & 861 & -0.024 & -0.0087 & -0.0063 & -0.0185 & 0.0094 & -0.0021 & 0.2597 & 0.1881 & 0.5522 \\
D4 & 860 & 0.0049 & 0.0036 & -0.0069 & -0.0043 & 0.0115 & 0.001 & -0.4737 & 0.9079 & 0.5658 \\
D5 & 857 & 0.0285 & 0.0167 & -0.0076 & 0.0008 & 0.0185 & 0.003 & 1.6869 & -0.7677 & 0.0808 \\
D6 & 863 & 0.059 & 0.0238 & -0.0022 & 0.0086 & 0.0242 & 0.0047 & 0.7881 & -0.0728 & 0.2848 \\
D7 & 863 & 0.0889 & 0.0311 & -0.0024 & 0.0249 & 0.0313 & 0.006 & 0.5802 & -0.0448 & 0.4646 \\
D8 & 858 & 0.1283 & 0.038 & 0.0075 & 0.0379 & 0.042 & 0.009 & 0.4556 & 0.0899 & 0.4544 \\
D9 & 863 & 0.2232 & 0.0444 & 0.018 & 0.0814 & 0.0683 & 0.011 & 0.3088 & 0.1252 & 0.5661 \\
D10 & 851 & 0.624 & 0.0403 & 0.0617 & 0.3821 & 0.1239 & 0.021 & 0.0832 & 0.1275 & 0.7893 \\
\hline
\end{tabular}

\begin{tabular}{lcccccccccc}
\hline \multicolumn{10}{c}{ Panel B. Equal-weighted Asset Growth Decomposition } \\
\hline Decile & $\mathrm{N}$ & AG & $\Delta$ RE & $\Delta$ Stock & $\Delta$ Debt & $\Delta$ OpLiab & $\Delta$ OthLS & RE & Stock & Debt \\
\hline All & 8584 & 0.0858 & 0.0151 & -0.0015 & 0.0325 & 0.026 & 0.0088 & 0.3275 & -0.0325 & 0.7050 \\
D1 & 848 & -0.1765 & -0.079 & -0.0122 & -0.0532 & -0.0312 & -0.015 & 0.5471 & 0.0845 & 0.3684 \\
D2 & 860 & -0.0585 & -0.0155 & -0.0205 & -0.019 & -0.0121 & -0.0057 & 0.2818 & 0.3727 & 0.3455 \\
D3 & 861 & -0.0208 & -0.001 & -0.0207 & -0.0129 & 0.0025 & -0.0033 & 0.0289 & 0.5983 & 0.3728 \\
D4 & 860 & 0.0063 & 0.0055 & -0.0175 & -0.0045 & 0.0092 & 0.0012 & -0.3333 & 1.0606 & 0.2727 \\
D5 & 857 & 0.0291 & 0.0217 & -0.0215 & 0.0026 & 0.0137 & 0.0053 & 7.7500 & -7.6786 & 0.9286 \\
D6 & 863 & 0.0544 & 0.0245 & -0.0142 & 0.0122 & 0.0189 & 0.0068 & 1.0889 & -0.6311 & 0.5422 \\
D7 & 863 & 0.086 & 0.0363 & -0.0171 & 0.0239 & 0.0281 & 0.0096 & 0.8422 & -0.3968 & 0.5545 \\
D8 & 858 & 0.1272 & 0.0403 & -0.0025 & 0.0406 & 0.0392 & 0.0122 & 0.5140 & -0.0319 & 0.5179 \\
D9 & 863 & 0.2099 & 0.0523 & 0.0079 & 0.0854 & 0.0543 & 0.0217 & 0.3592 & 0.0543 & 0.5865 \\
D10 & 851 & 0.6807 & 0.0459 & 0.065 & 0.3971 & 0.1487 & 0.0237 & 0.0904 & 0.1280 & 0.7817 \\
\hline
\end{tabular}




\section{Table 4: Yield Spread Portfolios and Asset Growth}

The table shows the time-series averages of value-weighted cross sectional means of asset growth. Each year, we double sort issuers into 25 groups based on the yield spread and the prior year asset growth rate. Q1 (Q5) represents issuers with the lowest (highest) yield spread. AG1 (AG5) represents issuers with the lowest (highest) asset growth rate.

\begin{tabular}{lcccccc}
\hline & Full Sample & AG 1 (low) & AG 2 & AG 3 & AG4 & AG5 (high) \\
\hline Q1 (Low) & 0.0912 & 0.0209 & 0.1237 & 0.1026 & 0.1281 & 0.1450 \\
Q2 & 0.0995 & 0.0465 & 0.0406 & 0.0887 & 0.1375 & 0.1596 \\
Q3 & 0.1186 & 0.1030 & 0.0973 & 0.1075 & 0.1712 & 0.1607 \\
Q4 & 0.1516 & -0.0001 & 0.0497 & 0.0979 & 0.1597 & 0.3655 \\
Q5 (High) & 0.0611 & 0.0233 & 0.0105 & 0.0853 & 0.1032 & 0.1715 \\
\hline
\end{tabular}


Table 5: Asset Growth Decile Portfolios and Yield Spread

The table shows the average yield spread of portfolios for all bonds and for the newly issued bonds respectively. Each year, we sort issuers into deciles based on asset growth rates. D1 (D10) represents issuers with the lowest (highest) asset growth rate. Yield spread is obtained at the beginning of the asset growth year. All bonds are also sorted into three profitability groups and quintiles (Q1-Q5) rating groups. The yield spread is the difference between the bond yield and the yield of a comparable maturity treasury bond. We repeat the same process, but sort all bonds by the absolute value of asset growth rate. No asset growth portfolio has the lowest absolute value of asset growth rate. Panel A reports yearly average yield spread of asset growth portfolios for all bonds. Panel B reports yearly average yield spread for newly issued corporate bonds. Newly issued bonds are defined as the bonds that are issued during the asset growth year. All numbers are in percentage. Inside the parenthesis are the Newey-West (1987) adjusted t-statistics with a 2 year lag. $* * *$ or $* * *$ signifies significance at the $10 \%, 5 \%$, or $1 \%$ level, respectively.

\begin{tabular}{|c|c|c|c|c|c|c|c|c|c|}
\hline \multicolumn{10}{|c|}{ Panel A. Full Bonds } \\
\hline \multirow[b]{2}{*}{ Decile } & \multirow{2}{*}{$\begin{array}{c}\text { Full } \\
\text { Sample }\end{array}$} & \multicolumn{3}{|c|}{ ROE Groups } & \multicolumn{5}{|c|}{ Rating Groups } \\
\hline & & Low & Medium & High & Q1 & Q2 & Q3 & Q4 & Q5 \\
\hline D1 & 3.98 & 4.87 & 2.29 & 4.05 & 7.36 & 3.94 & 2.14 & 1.36 & 0.68 \\
\hline $\mathrm{D} 2$ & 2.89 & 4.49 & 1.87 & 2.70 & 6.67 & 3.64 & 2.20 & 0.91 & 0.54 \\
\hline D3 & 2.59 & 3.35 & 2.25 & 1.90 & 5.90 & 3.07 & 1.83 & 1.00 & 1.15 \\
\hline D4 & 2.40 & 3.41 & 1.79 & 1.52 & 5.89 & 4.06 & 1.74 & 0.99 & 0.71 \\
\hline D5 & 1.88 & 3.30 & 1.64 & 1.15 & 5.33 & 2.90 & 1.51 & 1.05 & 0.55 \\
\hline D6 & 1.68 & 2.95 & 1.65 & 1.14 & 4.33 & 2.79 & 1.61 & 1.08 & 0.66 \\
\hline D7 & 1.83 & 2.79 & 1.70 & 1.42 & 5.57 & 2.94 & 1.55 & 0.82 & 0.73 \\
\hline D8 & 1.59 & 3.12 & 1.79 & 1.15 & 3.84 & 2.72 & 1.65 & 1.03 & 0.53 \\
\hline D9 & 1.76 & 2.93 & 2.03 & 1.44 & 3.66 & 2.42 & 1.76 & 1.01 & 0.67 \\
\hline D10 & 2.59 & 3.13 & 2.13 & 2.48 & 5.93 & 2.95 & 1.68 & 1.29 & 0.94 \\
\hline NG & 2.13 & 3.06 & 1.75 & 1.79 & 4.94 & 2.97 & 1.60 & 1.32 & 0.92 \\
\hline $\begin{array}{l}\text { Spread } \\
(10-1)\end{array}$ & $-1.39 * * *$ & $-1.73 * * *$ & -0.16 & $-1.56 * * *$ & $-3.55^{* * *}$ & $-0.99 * * *$ & $-0.46^{* * *}$ & -0.07 & 0.26 \\
\hline t-stat & -10.23 & -9.05 & -1.49 & -5.33 & -4.97 & -5.98 & -5.78 & -0.76 & 1.64 \\
\hline $\begin{array}{l}\text { Spread } \\
(10-N G)\end{array}$ & $0.46^{* * *}$ & 0.07 & $0.38^{* * *}$ & $0.69 * * *$ & $0.99 * *$ & 0.02 & 0.08 & -0.03 & 0.03 \\
\hline t-stat & 4.87 & 0.51 & 5.32 & 3.33 & 2.49 & 0.13 & 1.34 & -0.47 & 0.27 \\
\hline
\end{tabular}




\begin{tabular}{|c|c|c|c|c|c|c|c|c|c|}
\hline \multicolumn{10}{|c|}{ Panel B. Newly Issued Bonds } \\
\hline \multirow[b]{2}{*}{ Decile } & \multirow{2}{*}{$\begin{array}{c}\text { Full } \\
\text { Sample }\end{array}$} & \multicolumn{3}{|c|}{ ROE Groups } & \multicolumn{5}{|c|}{ Rating Groups } \\
\hline & & Low & Medium & High & Q1 & Q2 & Q3 & Q4 & Q5 \\
\hline D1 & 3.79 & 4.58 & 2.37 & 2.85 & 5.97 & 4.43 & 2.37 & 1.13 & 0.52 \\
\hline D2 & 2.76 & 4.66 & 2.48 & 2.04 & 5.40 & 4.03 & 1.74 & 0.82 & 1.07 \\
\hline D3 & 3.13 & 3.81 & 1.91 & 2.14 & 5.88 & 4.03 & 1.88 & 1.01 & 0.48 \\
\hline D4 & 2.40 & 3.85 & 2.52 & 2.08 & 5.22 & 4.32 & 1.76 & 0.98 & 0.52 \\
\hline D5 & 2.21 & 3.04 & 1.93 & 1.55 & 4.69 & 3.57 & 1.78 & 1.02 & 0.42 \\
\hline D6 & 2.53 & 3.43 & 2.30 & 1.55 & 5.18 & 3.48 & 1.84 & 0.91 & 0.53 \\
\hline D7 & 2.05 & 3.84 & 2.18 & 1.44 & 4.27 & 3.21 & 1.92 & 0.99 & 0.55 \\
\hline D8 & 2.20 & 3.71 & 2.40 & 1.56 & 4.32 & 3.22 & 1.61 & 1.05 & 0.68 \\
\hline D9 & 2.39 & 3.18 & 2.43 & 1.87 & 4.52 & 3.18 & 1.72 & 1.14 & 0.50 \\
\hline D10 & 3.04 & 4.22 & 3.03 & 2.14 & 4.72 & 3.32 & 1.49 & 1.00 & 1.61 \\
\hline NG & 2.64 & 3.47 & 1.95 & 2.23 & 5.49 & 4.28 & 1.73 & 1.01 & 0.42 \\
\hline $\begin{array}{l}\text { Spread } \\
(10-1)\end{array}$ & $-0.75 * * *$ & $-0.36^{*}$ & $-0.66 * * *$ & $-0.71 * * *$ & $-1.25 * * *$ & $-1.11 * * *$ & $-0.88 * * *$ & -0.14 & $1.09^{* *}$ \\
\hline t-stat & -6.29 & -1.86 & 4.04 & -3.69 & -8.22 & -5.22 & -8.40 & -1.47 & 2.01 \\
\hline $\begin{array}{l}\text { Spread } \\
(10-N G)\end{array}$ & $0.40 * * *$ & $0.75^{* * *}$ & $1.08 * * *$ & -0.09 & $-0.77 * * *$ & -0.96 & -0.24 & -0.02 & $1.19 * * *$ \\
\hline t-stat & 3.53 & 3.78 & 6.35 & -0.48 & -4.58 & -4.77 & -2.56 & -0.21 & 4.42 \\
\hline
\end{tabular}




\section{Table 6: Asset Growth and Its Determinants}

This table reports results of panel regressions with firm and year fixed effects. The dependent variable is asset growth. The panel is composed of various regressions speculations. We include firm characteristics such as prior year growth rate, ROE, log (assets), leverage. Bond characteristics (credit rating and years to maturity) are estimated at the bond issuer level. More details on the construction of these variables are provided in the Appendix. Year dummies are omitted from this table. T-statistics are in parentheses below each coefficient, and are adjusted for clustering at the firm-level. *, ** or *** signifies significance at the $10 \%, 5 \%$, or $1 \%$ level, respectively.

\begin{tabular}{|c|c|c|c|c|c|c|}
\hline & (1) & (2) & (3) & (4) & (5) & (6) \\
\hline Yldspread & $\begin{array}{c}-1.0626 * * * \\
(-8.22)\end{array}$ & $\begin{array}{c}-2.6838 * * * \\
(-8.86)\end{array}$ & & $\begin{array}{c}-2.9631 * * * \\
(-9.06)\end{array}$ & $\begin{array}{c}-2.2423 * * * \\
(-6.88)\end{array}$ & \\
\hline Yldspread-Sq & & $\begin{array}{c}5.8615^{* * *} \\
(6.41)\end{array}$ & & $\begin{array}{c}6.7002 * * * \\
\quad(7.08)\end{array}$ & $\begin{array}{c}5.1818^{* * * *} \\
(5.49)\end{array}$ & \\
\hline Yield & & & & & & $\begin{array}{c}-2.6698 * * * \\
(-7.33)\end{array}$ \\
\hline Yield-Sq & & & & & & $\begin{array}{c}5.5835 * * * \\
(6.03)\end{array}$ \\
\hline Lag AG & & & $\begin{array}{c}0.0293^{* *} \\
(2.49)\end{array}$ & $\begin{array}{c}0.0135 \\
(1.13)\end{array}$ & $\begin{array}{c}0.0119 \\
(0.99)\end{array}$ & $\begin{array}{c}0.0134 \\
(1.11)\end{array}$ \\
\hline Lag ROE & & & $\begin{array}{c}0.0171 * * * \\
(2.93)\end{array}$ & $\begin{array}{c}0.0138 * * \\
(2.48)\end{array}$ & $\begin{array}{c}0.0140 * * \\
(2.54)\end{array}$ & $\begin{array}{c}0.0139 * * \\
(2.54)\end{array}$ \\
\hline Log (Assets) & & & $\begin{array}{c}-0.2424 * * * \\
(-15.70)\end{array}$ & $\begin{array}{c}-0.2498 * * * \\
(-16.48)\end{array}$ & $\begin{array}{c}-0.2648 * * * * \\
(-17.38)\end{array}$ & $\begin{array}{c}-0.2658 * * * \\
(-17.40)\end{array}$ \\
\hline Lag Leverage & & & $\begin{array}{c}-0.3252 * * * \\
(-6.74)\end{array}$ & $\begin{array}{c}-0.2493 * * * \\
(-5.06)\end{array}$ & $\begin{array}{c}-0.2091 * * * \\
(-4.06)\end{array}$ & $\begin{array}{c}-0.2054 * * * \\
(-3.99)\end{array}$ \\
\hline Rating & & & & & $\begin{array}{c}0.0121 * * * \\
(3.81)\end{array}$ & $\begin{array}{c}0.0124 * * * \\
(3.93)\end{array}$ \\
\hline Maturity & & & & & $\begin{array}{c}0.0057 * * * \\
(4.39)\end{array}$ & $\begin{array}{c}0.0070 * * * \\
(5.25)\end{array}$ \\
\hline Constant & $\begin{array}{c}0.1702 * * * \\
(8.09)\end{array}$ & $\begin{array}{c}0.1899 * * * \\
(8.87)\end{array}$ & $\begin{array}{c}2.1216^{* * * *} \\
(17.05)\end{array}$ & $\begin{array}{c}2.1914 * * * \\
(17.86)\end{array}$ & $\begin{array}{c}2.0304 * * * \\
(16.51)\end{array}$ & $\begin{array}{c}2.1748 * * * \\
(16.92)\end{array}$ \\
\hline Observations & 8,375 & 8,375 & 8,375 & 8,375 & 8,375 & 8,375 \\
\hline Adj. R-sq & 0.250 & 0.255 & 0.340 & 0.357 & 0.364 & 0.364 \\
\hline
\end{tabular}


Table 7: Asset Growth Deciles: Yield and Yield Spread Changes

This table reports average yield spreads and yield spread changes across deciles based on asset growth. For all bonds sample, yield spread in year $\mathrm{t}$ is defined as the yield spread at the beginning of the asset growth year. Yield spread in year $t+1$ is the first available monthly transaction 6 months after asset growth year. For newly issued bonds, we use the yield spread of the first available trade after bond issuance. D1 decile has the highest asset growth rates. All the numbers reported are in percent. Inside the parenthesis are the Newey-West (1987) adjusted t-statistics with a 2 year lag. *, ** or *** signifies significance at the $10 \%, 5 \%$, or $1 \%$ level, respectively.

\begin{tabular}{lccccccccccccc}
\hline \multicolumn{10}{c}{ Panel A. All Bonds } \\
\hline \multicolumn{10}{c}{} & \multicolumn{1}{c}{ Full Sample } & \multicolumn{1}{c}{ Positive AG } & \multicolumn{1}{c}{ Negative AG } \\
\hline Decile & $\mathrm{t}$ & $\mathrm{t}+1$ & Change & $\mathrm{t}$-stat & $\mathrm{t}$ & $\mathrm{t}+1$ & Change & $\mathrm{t}$-stat & $\mathrm{t}$ & $\mathrm{t}+1$ & Change & $\mathrm{t}$-stat \\
D1 (Low) & 4.47 & 4.39 & $-0.085^{* * *}$ & -3.22 & 2.10 & 2.11 & 0.016 & 0.60 & 4.84 & 4.75 & $-0.089^{* * *}$ & -3.40 \\
D2 & 3.82 & 3.70 & $-0.123^{* *}$ & -2.39 & 2.17 & 2.19 & 0.018 & 0.68 & 4.76 & 4.60 & $-0.155^{* * *}$ & -3.71 \\
D3 & 2.80 & 2.71 & -0.094 & -1.17 & 1.78 & 1.78 & 0.005 & 0.07 & 4.25 & 4.15 & $-0.106^{* * *}$ & -3.36 \\
D4 & 2.42 & 2.49 & 0.069 & 0.81 & 1.75 & 1.79 & 0.039 & 0.74 & 3.94 & 3.75 & $-0.189 * * *$ & -2.76 \\
D5 & 2.01 & 1.84 & -0.170 & 1.02 & 1.75 & 1.76 & 0.041 & 0.64 & 3.32 & 3.20 & $-0.119^{* *}$ & -2.39 \\
D6 & 1.84 & 1.89 & 0.053 & 0.43 & 1.63 & 1.57 & -0.066 & -0.34 & 3.30 & 3.19 & -0.114 & -0.66 \\
D7 & 1.75 & 1.70 & -0.057 & -0.47 & 1.56 & 1.57 & 0.020 & 1.25 & 3.20 & 3.04 & -0.157 & -1.32 \\
D8 & 1.59 & 1.68 & $0.085^{*}$ & 1.86 & 1.62 & 1.70 & $0.080 * *$ & 2.25 & 2.90 & 2.95 & 0.045 & 1.54 \\
D9 & 1.84 & 1.91 & $0.067 * * *$ & 2.92 & 1.91 & 1.99 & $0.081 * * *$ & 2.58 & 2.60 & 2.67 & 0.066 & 1.17 \\
D10 (High) & 2.13 & 2.24 & $0.110^{* * *}$ & 3.70 & 2.14 & 2.24 & $0.102 * * *$ & 3.38 & 2.21 & 2.23 & 0.023 & 0.76 \\
\hline
\end{tabular}




\begin{tabular}{lccccccccccccc}
\hline \multicolumn{10}{c}{ Panel B. Newly Issued Bonds } \\
\hline \multicolumn{10}{c}{} & \multicolumn{1}{c}{ Full Sample } & \multicolumn{1}{c}{ Positive AG } & & \multicolumn{1}{c}{ Negative AG } \\
\hline Decile & $\mathrm{t}$ & $\mathrm{t}+1$ & Change & $\mathrm{t}$-stat & $\mathrm{t}$ & $\mathrm{t}+1$ & Change & $\mathrm{t}$-stat & $\mathrm{t}$ & $\mathrm{t}+1$ & Change & $\mathrm{t}$-stat \\
D1 (Low) & 4.33 & 4.12 & $-0.202^{* *}$ & -2.08 & 2.18 & 2.23 & 0.052 & 0.66 & 4.57 & 4.20 & $-0.364^{* *}$ & -2.40 \\
D2 & 2.89 & 2.85 & $-0.045^{* *}$ & -2.01 & 2.37 & 2.29 & -0.079 & -0.03 & 4.31 & 4.21 & $-0.095^{* *}$ & -1.98 \\
D3 & 2.37 & 2.33 & -0.046 & -1.46 & 1.88 & 1.86 & -0.023 & -1.28 & 3.67 & 3.58 & -0.089 & -1.32 \\
D4 & 2.14 & 2.15 & 0.006 & 0.65 & 1.89 & 1.76 & -0.132 & -1.40 & 2.64 & 2.77 & 0.134 & 1.40 \\
D5 & 2.14 & 2.09 & -0.055 & -0.68 & 1.83 & 1.92 & 0.089 & 0.76 & 3.40 & 3.26 & -0.140 & -0.74 \\
D6 & 1.74 & 1.68 & -0.054 & -1.15 & 2.14 & 2.21 & 0.079 & 0.56 & 3.18 & 3.26 & 0.074 & 0.63 \\
D7 & 1.67 & 1.69 & 0.018 & 0.23 & 2.03 & 2.14 & 0.112 & 1.20 & 2.75 & 2.65 & -0.101 & -0.89 \\
D8 & 2.12 & 2.25 & 0.132 & 1.43 & 2.15 & 2.25 & 0.100 & 1.31 & 2.75 & 2.81 & 0.057 & 0.29 \\
D9 & 2.21 & 2.27 & 0.059 & 1.22 & 2.26 & 2.36 & $0.104 *$ & 1.78 & 2.85 & 2.98 & 0.133 & 0.61 \\
D10 (High) & 2.42 & 2.52 & $0.098^{* * *}$ & 3.34 & 2.42 & 2.55 & $0.132 * * *$ & 2.86 & 2.64 & 2.74 & 0.103 & 1.10 \\
\hline
\end{tabular}




\section{Table 8: Asset Growth Effect on Yield Spread Changes}

The yield spread change determinants are based on firm-specific characteristics, bond-specific effects, macroeconomic variables. Annual changes in all variables are examined for 1994-2014 period. The liquidity is estimated by the Amihud measure. We use a cardinal scale for all bonds, regardless of whether they are investment grade or speculative grade bonds, ranging from 1 for $\mathrm{C}$ rated bonds, to 22 for Aaa rated bonds. The firm specific characteristics are operating income to sales, long-term debt to assets, total debt to capitalization, and excess stock daily volatility. T-note rate is the 1 year Treasury rate. Term-slope is the difference between the 10 year and 2 year Treasury rates. Eurodollar refers to the difference between the 30-day Eurodollar rate and the 3-month T-bill rate. More details on the construction of these variables are provided in the Appendix. T-statistics are presented in parentheses. The issuer is the fixed effect. $*, * *$ or $* * *$ signifies significance at the $10 \%, 5 \%$, or $1 \%$ level, respectively.

\begin{tabular}{|c|c|c|c|c|c|c|c|c|}
\hline & \multicolumn{5}{|c|}{ Full Sample } & \multicolumn{3}{|c|}{ Newly Issued Bonds } \\
\hline & (1) & (2) & (3) & (4) & (5) & (6) & (7) & (8) \\
\hline & Full & Full & Full & Positive AG & Negative AG & Full & Positive AG & Negative AG \\
\hline Asset Growth & $\begin{array}{c}0.4590 * * * \\
(4.88)\end{array}$ & $\begin{array}{c}0.3039 * * * \\
(3.55)\end{array}$ & $\begin{array}{c}0.2984 * * * \\
(3.62)\end{array}$ & $\begin{array}{c}0.2276 * * * \\
(2.87)\end{array}$ & $\begin{array}{c}1.7645 * * * \\
(2.61)\end{array}$ & $\begin{array}{c}0.2442 * * * \\
(3.82)\end{array}$ & $\begin{array}{c}0.2599 * * * \\
(2.70)\end{array}$ & $\begin{array}{c}1.6675 * * * \\
(2.69)\end{array}$ \\
\hline$\Delta$ (Rating) & & & $\begin{array}{c}-0.4104 * * * \\
(-13.83)\end{array}$ & $\begin{array}{c}-0.4531 * * * \\
(-10.09)\end{array}$ & $\begin{array}{c}-0.3793 * * * \\
(-8.36)\end{array}$ & $\begin{array}{c}-0.4408^{* * * *} \\
(-6.25)\end{array}$ & $\begin{array}{c}-0.4622 * * * \\
(-5.70)\end{array}$ & $\begin{array}{c}-0.4776^{* * * *} \\
(-2.69)\end{array}$ \\
\hline$\Delta$ (Amihud) & & & $\begin{array}{c}0.3362 * * * \\
(5.65)\end{array}$ & $\begin{array}{c}0.4130 * * * \\
(5.20)\end{array}$ & $\begin{array}{c}0.2100^{* * * *} \\
(3.72)\end{array}$ & $\begin{array}{c}0.3142 * * * \\
(4.71)\end{array}$ & $\begin{array}{c}0.2170^{* * * *} \\
(3.20)\end{array}$ & $\begin{array}{c}0.1703 * * * \\
(3.45)\end{array}$ \\
\hline$\Delta($ Pre-Tax & & $\begin{array}{r}-0.0043 \\
(-1.51)\end{array}$ & $\begin{array}{c}0.0003 \\
(0.12)\end{array}$ & $\begin{array}{c}0.0026 \\
(1.27)\end{array}$ & $\begin{array}{r}-0.0199 \\
(-1.62)\end{array}$ & $\begin{array}{c}-0.0011 \\
(-0.47)\end{array}$ & $\begin{array}{c}0.0001 \\
(0.03)\end{array}$ & $\begin{array}{c}0.0432 \\
(0.56)\end{array}$ \\
\hline $\begin{array}{c}\Delta \text { (Income } \\
\text { to Sales) }\end{array}$ & & $\begin{array}{c}-2.4387 * * * \\
(-5.21)\end{array}$ & $\begin{array}{c}-1.9924 * * * \\
(-4.58)\end{array}$ & $\begin{array}{c}-0.0038 \\
(-0.01)\end{array}$ & $\begin{array}{c}-6.2593 * * * \\
(-5.10)\end{array}$ & $\begin{array}{c}1.9213 * * \\
(2.20)\end{array}$ & $\begin{array}{c}2.0593^{* * *} \\
(2.23)\end{array}$ & $\begin{array}{l}1.4623 \\
(0.32)\end{array}$ \\
\hline $\begin{array}{l}\Delta \text { (LT Debt } \\
\quad \text { to Assets) }\end{array}$ & & $\begin{array}{c}-0.9527^{*} \\
(-1.74)\end{array}$ & $\begin{array}{c}-1.5833 * * * \\
(-3.04)\end{array}$ & $\begin{array}{c}-1.2464 * * * \\
(-2.95)\end{array}$ & $\begin{array}{c}-1.8628 \\
(-1.40)\end{array}$ & $\begin{array}{c}-0.1862 \\
(-0.22)\end{array}$ & $\begin{array}{c}0.4899 \\
(0.49)\end{array}$ & $\begin{array}{c}3.2638 \\
(0.76)\end{array}$ \\
\hline $\begin{array}{r}\Delta \text { (Debt to } \\
\text { Capital) }\end{array}$ & & $\begin{array}{c}5.6840 * * * \\
(9.43)\end{array}$ & $\begin{array}{c}4.5415^{* * *} \\
(7.83)\end{array}$ & $\begin{array}{c}3.8940 * * * \\
(8.07)\end{array}$ & $\begin{array}{c}5.7244 * * * \\
(4.48)\end{array}$ & $\begin{array}{l}1.1183 \\
(1.17)\end{array}$ & $\begin{array}{l}1.1016 \\
(1.06)\end{array}$ & $\begin{array}{l}1.9567 \\
(0.52)\end{array}$ \\
\hline$\Delta$ (Sdret) & & $\begin{array}{c}0.9645^{* * * *} \\
(20.97)\end{array}$ & $\begin{array}{c}0.4843^{* * *} * \\
(9.83)\end{array}$ & $\begin{array}{c}0.3927 * * * \\
(8.12)\end{array}$ & $\begin{array}{c}0.5711^{* * * *} \\
(6.81)\end{array}$ & $\begin{array}{c}-0.0923 \\
(-1.37)\end{array}$ & $\begin{array}{c}0.1096 \\
(1.40)\end{array}$ & $\begin{array}{c}-0.5668 * * * \\
(-2.73)\end{array}$ \\
\hline$\Delta$ (T-note) & & & $\begin{array}{c}0.3466^{* * * *} \\
(13.79)\end{array}$ & $\begin{array}{c}0.3026^{* * * *} \\
(11.89)\end{array}$ & $\begin{array}{c}0.5356^{* * * *} \\
(7.36)\end{array}$ & $\begin{array}{c}0.9831 * * * \\
(11.02)\end{array}$ & $\begin{array}{c}0.7977 * * * \\
(8.20)\end{array}$ & $\begin{array}{c}1.3726 * * * \\
(3.17)\end{array}$ \\
\hline$\Delta$ (Term slope $)$ & & & $\begin{array}{c}0.3821 * * * \\
(14.85)\end{array}$ & $\begin{array}{c}0.3842 * * * \\
(14.30)\end{array}$ & $\begin{array}{c}0.5914 * * * \\
(6.69)\end{array}$ & $\begin{array}{c}1.3211 * * * \\
(10.76)\end{array}$ & $\begin{array}{c}1.1683^{* * * *} \\
(9.20)\end{array}$ & $\begin{array}{c}2.0500^{* * *} \\
(2.77)\end{array}$ \\
\hline$\Delta$ (Eurodollar) & & & $\begin{array}{c}1.7656^{* * *} \\
(26.29)\end{array}$ & $\begin{array}{c}1.5112 * * * \\
(23.44)\end{array}$ & $\begin{array}{c}2.1274 * * * \\
(14.67)\end{array}$ & $\begin{array}{c}1.4591 * * * \\
(10.55)\end{array}$ & $\begin{array}{c}1.4168 * * * \\
(8.94)\end{array}$ & $\begin{array}{c}1.5446 * * * \\
(2.97)\end{array}$ \\
\hline Constant & $\begin{array}{c}0.0511^{* *} \\
(2.37)\end{array}$ & $\begin{array}{c}0.3002 * * * \\
(14.09)\end{array}$ & $\begin{array}{c}0.2262 * * * \\
(11.73)\end{array}$ & $\begin{array}{c}0.2244 * * * \\
(11.20)\end{array}$ & $\begin{array}{c}0.3618 * * * \\
(5.17)\end{array}$ & $\begin{array}{c}0.4726 * * * \\
(6.49)\end{array}$ & $\begin{array}{c}0.5708^{* * *} \\
(6.88)\end{array}$ & $\begin{array}{c}0.1934 \\
(0.53)\end{array}$ \\
\hline Observations & 22,178 & 22,178 & 22,178 & 15,415 & 6,763 & 2,892 & 2,327 & 565 \\
\hline Adj. R-sq & 0.148 & 0.282 & 0.356 & 0.389 & 0.502 & 0.623 & 0.677 & 0.804 \\
\hline
\end{tabular}




\section{Table 9: Asset Growth Effect: Pre-crisis, Crisis and Post Crisis Periods}

The yield spread change determinants are based on firm-specific characteristics, bond-specific effects, macroeconomic variables. Annual changes in all variables are examined for 1994-2014 period. Following the NBER, the recent financial crisis defined from December 2007 to June 2009 . The liquidity is estimated by the Amihud measure. We use a cardinal scale for all bonds, regardless of whether they are investment grade or speculative grade bonds, ranging from 1 for $\mathrm{C}$ rated bonds, to 22 for Aaa rated bonds. The firm specific characteristics are operating income to sales, long-term debt to assets, total debt to capitalization, and excess stock daily volatility. T-note rate is the 1 year Treasury rate. Term-slope is the difference between the 10 year and 2 year Treasury rates. Eurodollar refers to the difference between the 30-day Eurodollar rate and the 3-month T-bill rate. More details on the construction of these variables are provided in the Appendix. T-statistics are presented in parentheses. The issuer is the fixed effect. *,** or *** signifies significance at the $10 \%, 5 \%$, or $1 \%$ level, respectively.

\begin{tabular}{|c|c|c|c|c|c|c|c|c|c|}
\hline \multicolumn{10}{|c|}{ Panel A. Full Sample } \\
\hline & \multicolumn{3}{|c|}{ Pre-Crisis Period } & \multicolumn{3}{|c|}{ Crisis Period } & \multicolumn{3}{|c|}{ Post Crisis Period } \\
\hline & (1) & (2) & (3) & (4) & (5) & (6) & (7) & (8) & (9) \\
\hline & Full & Positive AG & Negative AG & Full & Positive AG & Negative AG & Full & Positive AG & Negative AG \\
\hline Asset Growth & $\begin{array}{c}0.1326^{*} \\
(1.89)\end{array}$ & $\begin{array}{c}0.2373 * * * \\
(2.99)\end{array}$ & $\begin{array}{c}-2.7598 * * \\
(-2.52)\end{array}$ & $\begin{array}{c}-1.6367 * * * \\
(-3.32)\end{array}$ & $\begin{array}{c}1.0232 * \\
(1.80)\end{array}$ & $\begin{array}{l}1.0698 \\
(0.25)\end{array}$ & $\begin{array}{c}0.3961 * * * \\
(4.10)\end{array}$ & $\begin{array}{c}0.2886 * * * \\
(3.13)\end{array}$ & $\begin{array}{c}2.4993 * * * \\
(3.02)\end{array}$ \\
\hline$\Delta$ (Rating) & $\begin{array}{c}-0.2581 * * * \\
(-5.31)\end{array}$ & $\begin{array}{c}-0.3428 * * * \\
(-5.96)\end{array}$ & $\begin{array}{c}-0.1052 \\
(-1.29)\end{array}$ & $\begin{array}{c}-0.4727 * * * \\
(-3.79)\end{array}$ & $\begin{array}{c}-0.0611 \\
(-0.43)\end{array}$ & $\begin{array}{c}-0.4446^{*} \\
(-1.94)\end{array}$ & $\begin{array}{c}-0.4410 * * * \\
(-12.43)\end{array}$ & $\begin{array}{c}-0.5261 * * * \\
(-9.65)\end{array}$ & $\begin{array}{c}-0.4240 * * * \\
(-7.72)\end{array}$ \\
\hline$\Delta$ (Amihud) & $\begin{array}{c}0.2118 * * * \\
(6.32)\end{array}$ & $\begin{array}{c}0.2306 * * * \\
(4.51)\end{array}$ & $\begin{array}{c}0.1300 * * \\
(2.12)\end{array}$ & $\begin{array}{c}0.4578 * * * \\
(12.16)\end{array}$ & $\begin{array}{c}0.3126^{* *} \\
(7.85)\end{array}$ & $\begin{array}{c}0.1578^{* * * *} \\
(5.65)\end{array}$ & $\begin{array}{c}0.1880 * * * \\
(7.36)\end{array}$ & $\begin{array}{c}0.1659 * * * \\
(5.39)\end{array}$ & $\begin{array}{c}0.1279 * * * \\
(4.87)\end{array}$ \\
\hline $\begin{array}{r}\Delta(\text { Pre-Tax } \\
\text { Interest) }\end{array}$ & $\begin{array}{c}-0.0038 \\
(-1.29)\end{array}$ & $\begin{array}{c}0.0025 \\
(1.02)\end{array}$ & $\begin{array}{c}-0.0144 \\
(-1.01)\end{array}$ & $\begin{array}{c}-0.0913 * * * \\
(-4.99)\end{array}$ & $\begin{array}{c}-0.0613 * * * \\
(-4.64)\end{array}$ & $\begin{array}{c}0.2801^{*} \\
(1.85)\end{array}$ & $\begin{array}{c}-0.0021 \\
(-0.43)\end{array}$ & $\begin{array}{r}-0.0017 \\
(-0.46)\end{array}$ & $\begin{array}{r}-0.0061 \\
(-0.33)\end{array}$ \\
\hline $\begin{array}{c}\Delta \text { (Income } \\
\quad \text { to Sales })\end{array}$ & $\begin{array}{r}-0.7007 \\
(-1.57)\end{array}$ & $\begin{array}{c}0.2370 \\
(0.57)\end{array}$ & $\begin{array}{c}-3.8929 * * * \\
(-2.71)\end{array}$ & $\begin{array}{c}-1.6991 \\
(-0.82)\end{array}$ & $\begin{array}{c}1.2111 \\
(0.65)\end{array}$ & $\begin{array}{c}-18.8753^{* * * *} \\
(-3.25)\end{array}$ & $\begin{array}{c}-4.0128 * * * \\
(-5.22)\end{array}$ & $\begin{array}{c}0.3041 \\
(0.46)\end{array}$ & $\begin{array}{c}-12.0094 * * * \\
(-6.11)\end{array}$ \\
\hline $\begin{array}{l}\Delta \text { (LT Debt } \\
\quad \text { to Assets) }\end{array}$ & $\begin{array}{c}-1.4010^{*} \\
(-1.73)\end{array}$ & $\begin{array}{c}-0.0587 \\
(-0.06)\end{array}$ & $\begin{array}{c}-4.5372 * * \\
(-2.23)\end{array}$ & $\begin{array}{c}4.0192^{*} \\
(1.65)\end{array}$ & $\begin{array}{c}-3.3348^{*} \\
(-1.72)\end{array}$ & $\begin{array}{l}5.3197 \\
(0.58)\end{array}$ & $\begin{array}{c}-1.4472^{* *} \\
(-2.23)\end{array}$ & $\begin{array}{c}-1.6255^{* * *} * \\
(-3.02)\end{array}$ & $\begin{array}{c}-1.1930 \\
(-0.75)\end{array}$ \\
\hline $\begin{array}{l}\Delta \text { (Debt to } \\
\text { Capital) }\end{array}$ & $\begin{array}{c}6.0500 * * * \\
(6.61)\end{array}$ & $\begin{array}{c}5.8121 * * * \\
(6.32)\end{array}$ & $\begin{array}{c}8.4525 * * * \\
(3.75)\end{array}$ & $\begin{array}{l}1.5197 \\
(0.73)\end{array}$ & $\begin{array}{c}4.3894 * * * \\
(3.03)\end{array}$ & $\begin{array}{c}6.0018 \\
(0.94)\end{array}$ & $\begin{array}{c}3.7726 * * * \\
(5.41)\end{array}$ & $\begin{array}{c}3.5614 * * * \\
(6.18)\end{array}$ & $\begin{array}{c}5.0717 * * * \\
(3.32)\end{array}$ \\
\hline$\Delta$ (Sdret) & $\begin{array}{c}0.8553 * * * \\
(10.52)\end{array}$ & $\begin{array}{c}0.3799 * * * \\
(4.76)\end{array}$ & $\begin{array}{c}1.0898 * * * \\
(7.28)\end{array}$ & $\begin{array}{c}2.4203^{* * * *} \\
(14.68)\end{array}$ & $\begin{array}{c}0.8820 * * * \\
\quad(5.87)\end{array}$ & $\begin{array}{c}2.4579 * * * \\
(7.25)\end{array}$ & $\begin{array}{c}0.5607 * * * \\
\quad(9.73)\end{array}$ & $\begin{array}{c}0.4724 * * * \\
(8.34)\end{array}$ & $\begin{array}{c}0.6548 * * * \\
\quad(6.78)\end{array}$ \\
\hline$\Delta$ (T-note) & $\begin{array}{c}0.5891 * * * \\
(14.88)\end{array}$ & $\begin{array}{c}0.3781 * * * \\
(8.62)\end{array}$ & $\begin{array}{c}1.1397 * * * \\
(12.08)\end{array}$ & $\begin{array}{c}0.9345^{* * * *} \\
(5.76)\end{array}$ & $\begin{array}{c}-0.1588 \\
(-1.00)\end{array}$ & $\begin{array}{c}0.4084 \\
(1.02)\end{array}$ & $\begin{array}{c}0.6608 * * * \\
(13.83)\end{array}$ & $\begin{array}{c}0.5657 * * * \\
(11.63)\end{array}$ & $\begin{array}{c}0.9629 * * * \\
(6.15)\end{array}$ \\
\hline$\Delta$ (Term slope $)$ & $\begin{array}{c}0.1665^{* * *} \\
\quad(6.25)\end{array}$ & $\begin{array}{l}0.2217 * * * \\
\quad(7.12)\end{array}$ & $\begin{array}{c}0.3578^{* * * *} \\
\quad(3.78)\end{array}$ & $\begin{array}{c}0.1689 * * * \\
(6.34)\end{array}$ & $\begin{array}{c}0.2492 * * * \\
\quad(8.35)\end{array}$ & $\begin{array}{c}0.1931^{* * *} \\
(1.99)\end{array}$ & $\begin{array}{c}0.8644 * * * \\
(13.31)\end{array}$ & $\begin{array}{c}0.7911 * * * \\
(11.79)\end{array}$ & $\begin{array}{c}1.2996^{* * * *} \\
(5.95)\end{array}$ \\
\hline$\Delta$ (Eurodollar) & $\begin{array}{c}1.2277 * * * \\
(16.17)\end{array}$ & $\begin{array}{c}1.0460 * * * \\
(12.66)\end{array}$ & $\begin{array}{c}1.8738 * * * \\
(10.27)\end{array}$ & $\begin{array}{c}1.7523 * * * \\
(26.52)\end{array}$ & $\begin{array}{c}1.6879 * * * \\
(25.57)\end{array}$ & $\begin{array}{c}2.2678 * * * \\
(13.99)\end{array}$ & $\begin{array}{c}1.7512 * * * \\
(25.13)\end{array}$ & $\begin{array}{c}1.4625 * * * \\
(21.72)\end{array}$ & $\begin{array}{c}2.0503 * * * \\
(12.67)\end{array}$ \\
\hline Constant & $\begin{array}{c}0.0885^{* * * *} \\
\quad(3.41)\end{array}$ & $\begin{array}{c}0.0033 \\
(0.11)\end{array}$ & $\begin{array}{c}0.2607 * * * \\
\quad(2.67)\end{array}$ & $\begin{array}{c}0.2004 \\
(0.66)\end{array}$ & $\begin{array}{c}-1.1639 * * * \\
(-3.65)\end{array}$ & $\begin{array}{c}-1.4677^{*} \\
(-1.77)\end{array}$ & $\begin{array}{c}0.3069 * * * \\
(11.38)\end{array}$ & $\begin{array}{c}0.3375^{* * *} \\
(12.59)\end{array}$ & $\begin{array}{c}0.4099 * * * \\
\quad(4.18)\end{array}$ \\
\hline Observations & 9,400 & 6,424 & 2,976 & 2,918 & 1,591 & 1,327 & 15,696 & 10,582 & 5,114 \\
\hline Adj. R-sq & 0.398 & 0.523 & 0.563 & 0.599 & 0.900 & 0.708 & 0.378 & 0.428 & 0.537 \\
\hline
\end{tabular}




\begin{tabular}{|c|c|c|c|c|c|c|c|c|c|}
\hline \multicolumn{10}{|c|}{ Panel B. Newly Issued Bonds } \\
\hline & \multicolumn{3}{|c|}{ Pre-Crisis Period } & \multicolumn{3}{|c|}{ Crisis Period } & \multicolumn{3}{|c|}{ Post Crisis Period } \\
\hline & (1) & (2) & (3) & (4) & (5) & (6) & (7) & (8) & (9) \\
\hline & Full & Positive AG & Negative AG & Full & Positive AG & Negative AG & Full & Positive AG & Negative AG \\
\hline Asset Growth & $\begin{array}{c}0.1531 * * \\
(2.07)\end{array}$ & $\begin{array}{c}0.1146^{* *} \\
(1.97)\end{array}$ & $\begin{array}{c}-0.3266 \\
(-0.06)\end{array}$ & $\begin{array}{c}-3.0474 * * \\
(-2.47)\end{array}$ & $\begin{array}{c}-6.2121 * * \\
(-2.53)\end{array}$ & $\begin{array}{c}-12.4808^{*} \\
(-2.01)\end{array}$ & $\begin{array}{c}0.7449 * * \\
(2.21)\end{array}$ & $\begin{array}{c}0.9469^{* *} \\
(2.05)\end{array}$ & $\begin{array}{c}3.5123 * * * \\
(5.93)\end{array}$ \\
\hline$\Delta$ (Rating) & $\begin{array}{c}-0.4398 * * * \\
(-5.63)\end{array}$ & $\begin{array}{c}-0.4347 * * * \\
(-5.96)\end{array}$ & $\begin{array}{c}-0.5471 * * * \\
(-3.33)\end{array}$ & $\begin{array}{c}0.2877 \\
(0.87)\end{array}$ & $\begin{array}{c}0.2502 \\
(0.71)\end{array}$ & $\begin{array}{c}0.6886 \\
(1.37)\end{array}$ & $\begin{array}{c}-0.1078 \\
(-1.18)\end{array}$ & $\begin{array}{c}-0.1169 \\
(-1.26)\end{array}$ & $\begin{array}{c}0.2550 \\
(0.72)\end{array}$ \\
\hline$\Delta$ (Amihud) & $\begin{array}{c}0.1198 * * * \\
(4.31)\end{array}$ & $\begin{array}{c}0.1856^{* * * *} \\
(3.51)\end{array}$ & $\begin{array}{c}0.1201^{*} \\
(1.81)\end{array}$ & $\begin{array}{c}0.4214 * * * \\
(6.88)\end{array}$ & $\begin{array}{c}0.3500 * * * \\
(7.36)\end{array}$ & $\begin{array}{c}0.4136^{* *} \\
(6.81)\end{array}$ & $\begin{array}{c}0.1671 * * * \\
(4.60)\end{array}$ & $\begin{array}{c}0.1781 * * * \\
(3.32)\end{array}$ & $\begin{array}{c}0.1252 * * * \\
\quad(4.21)\end{array}$ \\
\hline $\begin{array}{r}\Delta(\text { Pre-Tax } \\
\text { Interest })\end{array}$ & $\begin{array}{r}-0.0147 \\
(-1.22)\end{array}$ & $\begin{array}{c}-0.0173 \\
(-1.34)\end{array}$ & $\begin{array}{l}0.0134 \\
(0.13)\end{array}$ & $\begin{array}{c}-0.0134 \\
(-0.25)\end{array}$ & $\begin{array}{c}0.1079 * * \\
(2.50)\end{array}$ & $\begin{array}{c}1.1837 * * * \\
(4.88)\end{array}$ & $\begin{array}{c}0.0012 \\
(0.56)\end{array}$ & $\begin{array}{l}0.0027 \\
(1.25)\end{array}$ & $\begin{array}{c}2.4011^{* * *} * \\
(3.46)\end{array}$ \\
\hline $\begin{array}{c}\Delta \text { (Income } \\
\text { to Sales) }\end{array}$ & $\begin{array}{c}4.8152 \\
(1.35)\end{array}$ & $\begin{array}{c}6.2203 \\
(1.50)\end{array}$ & $\begin{array}{c}-1.2761 \\
(-0.23)\end{array}$ & $\begin{array}{l}1.3669 \\
(0.24)\end{array}$ & $\begin{array}{c}-17.9216^{* * * *} \\
(-2.96)\end{array}$ & $\begin{array}{c}-20.3589 * * * \\
(-3.94)\end{array}$ & $\begin{array}{c}0.5412 \\
(1.32)\end{array}$ & $\begin{array}{c}0.5954 \\
(1.62)\end{array}$ & $\begin{array}{c}-102.2458^{* * *} \\
(-3.43)\end{array}$ \\
\hline $\begin{array}{l}\Delta \text { (LT Debt } \\
\quad \text { to Assets) }\end{array}$ & $\begin{array}{c}-2.1036 * * \\
(-2.01)\end{array}$ & $\begin{array}{c}-2.5742 * * \\
(-2.01)\end{array}$ & $\begin{array}{c}3.6624 \\
(0.75)\end{array}$ & $\begin{array}{c}-7.0514 \\
(-0.93)\end{array}$ & $\begin{array}{c}-9.5387 \\
(-1.31)\end{array}$ & $\begin{array}{c}-9.6369 \\
(-1.11)\end{array}$ & $\begin{array}{c}-2.3171 \\
(-1.63)\end{array}$ & $\begin{array}{c}0.1484 \\
(0.15)\end{array}$ & $\begin{array}{c}75.6373 * * * \\
(4.65)\end{array}$ \\
\hline $\begin{array}{c}\Delta \text { (Debt to } \\
\quad \text { Capital) }\end{array}$ & $\begin{array}{l}1.0734 \\
(0.92)\end{array}$ & $\begin{array}{c}2.2597 * \\
(1.77)\end{array}$ & $\begin{array}{c}-4.9872 \\
(-1.43)\end{array}$ & $\begin{array}{c}4.7357 \\
(0.91)\end{array}$ & $\begin{array}{c}-8.3020 \\
(-1.06)\end{array}$ & $\begin{array}{c}4.9769 * \\
(1.87)\end{array}$ & $\begin{array}{c}-1.7372 \\
(-0.84)\end{array}$ & $\begin{array}{c}-4.0676^{*} \\
(-1.89)\end{array}$ & $\begin{array}{c}4.8977 \\
(0.35)\end{array}$ \\
\hline$\Delta$ (Sdret) & $\begin{array}{c}0.1214 \\
(1.20)\end{array}$ & $\begin{array}{c}0.1899^{*} \\
(1.65)\end{array}$ & $\begin{array}{c}0.1849 \\
(0.68)\end{array}$ & $\begin{array}{c}0.2677 \\
(0.76)\end{array}$ & $\begin{array}{l}-0.1707 \\
(-0.21)\end{array}$ & $\begin{array}{c}-1.1654 * * \\
(-2.52)\end{array}$ & $\begin{array}{c}-0.2621 * * \\
(-2.20)\end{array}$ & $\begin{array}{c}-0.1108 \\
(-0.56)\end{array}$ & $\begin{array}{c}-1.3839 * * * \\
(-6.66)\end{array}$ \\
\hline$\Delta$ (T-note) & $\begin{array}{c}1.2498 * * * \\
(8.53)\end{array}$ & $\begin{array}{c}1.0601 * * * * \\
(5.86)\end{array}$ & $\begin{array}{c}1.7786^{* * * *} \\
(2.93)\end{array}$ & $\begin{array}{c}0.5746 \\
(1.29)\end{array}$ & $\begin{array}{c}0.3096 \\
(0.47)\end{array}$ & $\begin{array}{c}-4.6656 * * \\
(-2.54)\end{array}$ & $\begin{array}{c}-2.1986 \\
(-1.12)\end{array}$ & $\begin{array}{c}-0.6555 \\
(-0.31)\end{array}$ & $\begin{array}{c}-66.0958 * * * \\
(-4.12)\end{array}$ \\
\hline$\Delta$ (Term slope $)$ & $\begin{array}{c}2.3218 * * * \\
(9.25)\end{array}$ & $\begin{array}{c}1.9972 * * * \\
(6.52)\end{array}$ & $\begin{array}{c}3.5911 * * * \\
(3.04)\end{array}$ & $\begin{array}{c}2.3670 * * * \\
(4.27)\end{array}$ & $\begin{array}{c}1.5398 * * * \\
(3.95)\end{array}$ & $\begin{array}{c}2.6426^{* * * *} \\
-3.89\end{array}$ & $\begin{array}{c}-0.0292 \\
(-0.11)\end{array}$ & $\begin{array}{c}0.1528 \\
(0.53)\end{array}$ & $\begin{array}{c}-6.9676^{* * * *} \\
(-3.11)\end{array}$ \\
\hline$\Delta$ (Eurodollar) & $\begin{array}{c}4.3351^{* * * *} \\
(9.43)\end{array}$ & $\begin{array}{c}3.5689 * * * \\
(6.83)\end{array}$ & $\begin{array}{c}5.6792 * * * \\
(3.47)\end{array}$ & $\begin{array}{c}0.3199 \\
(1.16)\end{array}$ & $\begin{array}{c}0.1140 \\
(0.34)\end{array}$ & $\begin{array}{c}0.2160 \\
(0.54)\end{array}$ & $\begin{array}{c}-1.5145^{* * *} \\
(-2.73)\end{array}$ & $\begin{array}{c}-1.6639 * * * \\
(-2.85)\end{array}$ & $\begin{array}{c}10.2306^{* * * *} \\
(3.77)\end{array}$ \\
\hline Constant & $\begin{array}{c}0.4684 * * * \\
(4.45)\end{array}$ & $\begin{array}{c}0.4639 * * * \\
(3.75)\end{array}$ & $\begin{array}{c}0.0277 \\
(0.07)\end{array}$ & $\begin{array}{c}-0.2698 \\
(-0.28)\end{array}$ & $\begin{array}{l}1.1667 \\
(0.82)\end{array}$ & $\begin{array}{c}-2.1033 \\
(-0.97)\end{array}$ & $\begin{array}{c}-0.7749 * * * \\
(-3.02)\end{array}$ & $\begin{array}{c}-0.5052^{*} \\
(-1.73)\end{array}$ & $\begin{array}{l}5.6697 \\
(0.98)\end{array}$ \\
\hline Observations & 1,681 & 1,348 & 333 & 267 & 208 & 140 & 799 & 667 & 132 \\
\hline Adj. R-sq & 0.689 & 0.705 & 0.904 & 0.835 & 0.849 & 0.956 & 0.850 & 0.901 & 0.957 \\
\hline
\end{tabular}




\section{Table 10: Asset Growth Effect: Investment Grade and Speculative Grade Bonds}

The yield spread change determinants are based on firm-specific characteristics, bond-specific effects, macroeconomic variables. We use a cardinal scale for all bonds, regardless of whether they are investment grade or speculative grade bonds, ranging from 1 for $\mathrm{C}$ rated bonds, to 22 for Aaa rated bonds. The firm specific characteristics are operating income to sales, long-term debt to assets, total debt to capitalization, excess stock daily return and equity volatility. T-note rate is the 1 year Treasury rate. Term-slope is the difference between the 10 year and 2 year Treasury rates. Eurodollar refers to the difference between the 30-day Eurodollar rate and the 3-month T-bill rate. More details on the construction of these variables are provided in the Appendix. Investment grade bonds are numbered from 13 (Baa3 rated bonds) to 22 (Aaa rated bonds). Speculative grade bonds are numbered from 1 (C rated bonds) to 12 (Ba1 rated bonds). The issuer is the fixed effect. *,** or *** signifies significance at the $10 \%, 5 \%$, or $1 \%$ level, respectively.

Panel A. Full Sample

\begin{tabular}{|c|c|c|c|c|c|c|}
\hline & \multicolumn{3}{|c|}{ Investment Grade Bonds } & \multicolumn{3}{|c|}{ Speculative Grade Bonds } \\
\hline & (1) & (2) & (3) & (4) & (5) & (6) \\
\hline & Full & Positive AG & Negative AG & Full & Positive AG & Negative AG \\
\hline Asset Growth & $\begin{array}{c}0.1614 * * * * \\
(3.08)\end{array}$ & $\begin{array}{c}0.2192^{* * * *} \\
(3.64)\end{array}$ & $\begin{array}{c}0.5078 \\
(1.03)\end{array}$ & $\begin{array}{c}0.4691 * * * \\
(2.66)\end{array}$ & $\begin{array}{c}0.5100 * * * \\
(2.78)\end{array}$ & $\begin{array}{c}4.1944 * * * \\
(3.47)\end{array}$ \\
\hline$\Delta$ (Rating) & $\begin{array}{c}-0.2879 * * * \\
(-10.40)\end{array}$ & $\begin{array}{c}-0.3046 * * * \\
(-8.20)\end{array}$ & $\begin{array}{c}-0.3854 * * * \\
(-6.39)\end{array}$ & $\begin{array}{c}-0.5086 * * * \\
(-10.04)\end{array}$ & $\begin{array}{c}-0.5192 * * * \\
(-5.99)\end{array}$ & $\begin{array}{c}-0.4987 * * * \\
(-7.10)\end{array}$ \\
\hline$\Delta$ (Amihud) & $\begin{array}{c}0.2909 * * \\
(2.34)\end{array}$ & $\begin{array}{c}0.2306 * * * \\
(2.89)\end{array}$ & $\begin{array}{c}0.1354 * * \\
(2.26)\end{array}$ & $\begin{array}{c}1.1513 * * * \\
(3.26)\end{array}$ & $\begin{array}{c}1.1365^{* *} \\
(2.20)\end{array}$ & $\begin{array}{c}1.4616^{* *} \\
(2.43)\end{array}$ \\
\hline $\begin{array}{r}\Delta(\text { Pre-Tax } \\
\text { Interest })\end{array}$ & $\begin{array}{c}0.0009 \\
(0.56)\end{array}$ & $\begin{array}{c}0.0007 \\
(0.47)\end{array}$ & $\begin{array}{c}-0.0024 \\
(-0.29)\end{array}$ & $\begin{array}{c}-0.0298 * \\
(-1.68)\end{array}$ & $\begin{array}{c}-0.0122 \\
(-0.72)\end{array}$ & $\begin{array}{c}-0.0590 \\
(-1.61)\end{array}$ \\
\hline $\begin{array}{c}\Delta \text { (Income } \\
\text { to Sales })\end{array}$ & $\begin{array}{c}0.0993 \\
(0.38)\end{array}$ & $\begin{array}{c}0.8351^{* *} \\
(2.24)\end{array}$ & $\begin{array}{c}-1.6275^{* *} \\
(-2.20)\end{array}$ & $\begin{array}{c}-1.9500 * * \\
(-2.53)\end{array}$ & $\begin{array}{c}0.5094 \\
(0.78)\end{array}$ & $\begin{array}{c}-5.7594 * * * \\
(-3.23)\end{array}$ \\
\hline $\begin{array}{l}\Delta \text { (LT Debt } \\
\text { to Assets) }\end{array}$ & $\begin{array}{c}-0.6701 * * * \\
(-2.89)\end{array}$ & $\begin{array}{c}-0.8980 * * * \\
(-3.26)\end{array}$ & $\begin{array}{c}-0.4421 \\
(-0.81)\end{array}$ & $\begin{array}{c}-2.7186^{* *} \\
(-2.52)\end{array}$ & $\begin{array}{c}-2.5262 * * \\
(-2.47)\end{array}$ & $\begin{array}{c}-2.1406 \\
(-0.98)\end{array}$ \\
\hline $\begin{array}{r}\Delta \text { (Debt to } \\
\text { Capital) }\end{array}$ & $\begin{array}{c}2.1679 * * * \\
(7.26)\end{array}$ & $\begin{array}{c}2.1144 * * * \\
(6.23)\end{array}$ & $\begin{array}{c}3.5075^{* * * *} \\
(5.20)\end{array}$ & $\begin{array}{c}5.9271 * * * \\
(5.53)\end{array}$ & $\begin{array}{c}4.6727 * * * \\
(4.64)\end{array}$ & $\begin{array}{c}6.1535 * * * \\
\quad(3.08)\end{array}$ \\
\hline$\Delta$ (Sdret) & $\begin{array}{c}0.0715^{* *} \\
(2.44)\end{array}$ & $\begin{array}{c}0.1575^{* * * *} \\
(4.47)\end{array}$ & $\begin{array}{c}-0.2706 * * * \\
(-4.25)\end{array}$ & $\begin{array}{c}0.4536 * * * \\
(5.51)\end{array}$ & $\begin{array}{c}0.5641 * * * \\
(4.91)\end{array}$ & $\begin{array}{c}0.5116^{* * * *} \\
(4.56)\end{array}$ \\
\hline$\Delta$ (T-note) & $\begin{array}{c}0.2757 * * * \\
(17.90)\end{array}$ & $\begin{array}{c}0.2490 * * * \\
(13.78)\end{array}$ & $\begin{array}{c}0.3972 \text { *** } \\
(8.81)\end{array}$ & $\begin{array}{c}0.5867 * * * \\
(7.30)\end{array}$ & $\begin{array}{c}0.5524 * * * \\
(5.67)\end{array}$ & $\begin{array}{c}0.7130 * * * \\
(4.00)\end{array}$ \\
\hline$\Delta$ (Term slope $)$ & $\begin{array}{c}0.2235^{* * *} \\
(14.14)\end{array}$ & $\begin{array}{c}0.2328 * * * \\
(13.52)\end{array}$ & $\begin{array}{c}0.3189 * * * \\
\quad(5.48)\end{array}$ & $\begin{array}{c}0.8706 * * * \\
\quad(9.92)\end{array}$ & $\begin{array}{c}0.9831 \text { *** } \\
(8.83)\end{array}$ & $\begin{array}{c}0.9693 * * * \\
(4.55)\end{array}$ \\
\hline$\Delta$ (Eurodollar) & $\begin{array}{c}1.2567 * * * \\
(35.67)\end{array}$ & $\begin{array}{c}1.2560^{* * *} \\
(32.14)\end{array}$ & $\begin{array}{c}1.3692 * * * \\
(15.31)\end{array}$ & $\begin{array}{c}3.7875 * * * \\
(18.41)\end{array}$ & $\begin{array}{c}3.1871 * * * \\
(10.48)\end{array}$ & $\begin{array}{c}4.1651 * * * \\
(13.47)\end{array}$ \\
\hline Constant & $\begin{array}{c}0.1281^{* * *} \\
(11.02)\end{array}$ & $\begin{array}{c}0.1348 * * * \\
(9.81)\end{array}$ & $\begin{array}{c}0.1259 * * * \\
(3.40)\end{array}$ & $\begin{array}{c}0.2392 * * * \\
(3.73)\end{array}$ & $\begin{array}{c}0.3410 * * * \\
(4.36)\end{array}$ & $\begin{array}{c}0.5242 * * * \\
\quad(3.18)\end{array}$ \\
\hline Observations & 15,902 & 11,993 & 3,909 & 6,276 & 3,422 & 2,854 \\
\hline Adj. R-sq & 0.323 & 0.352 & 0.398 & 0.447 & 0.501 & 0.564 \\
\hline
\end{tabular}




\begin{tabular}{|c|c|c|c|c|c|c|}
\hline \multicolumn{7}{|c|}{ Panel B. Newly Issued Bonds } \\
\hline & \multicolumn{3}{|c|}{ Investment Grade Bonds } & \multicolumn{3}{|c|}{ Speculative Grade Bonds } \\
\hline & (1) & (2) & (3) & (4) & (5) & (6) \\
\hline & Full & Positive AG & Negative AG & Full & Positive AG & Negative AG \\
\hline Asset Growth & $\begin{array}{c}0.5407 * * * \\
(3.88)\end{array}$ & $\begin{array}{c}0.5061 * * * \\
(3.00)\end{array}$ & $\begin{array}{c}-1.8212 \\
(-0.72)\end{array}$ & $\begin{array}{c}0.3205 * * * \\
(3.57)\end{array}$ & $\begin{array}{c}0.2061 * * * \\
(2.88)\end{array}$ & $\begin{array}{l}6.5001 \\
(1.02)\end{array}$ \\
\hline$\Delta$ (Rating) & $\begin{array}{c}-0.2553 * * * \\
(-3.70)\end{array}$ & $\begin{array}{c}-0.2780 * * * \\
(-3.47)\end{array}$ & $\begin{array}{c}-0.0060 \\
(-0.04)\end{array}$ & $\begin{array}{c}-0.6265 * * * \\
(-3.96)\end{array}$ & $\begin{array}{c}-0.7747 * * * \\
(-4.28)\end{array}$ & $\begin{array}{c}-0.4463 \\
(-1.47)\end{array}$ \\
\hline$\Delta$ (Amihud) & $\begin{array}{c}0.1819^{* *} \\
(2.20)\end{array}$ & $\begin{array}{c}0.2203^{* * *} * \\
(2.91)\end{array}$ & $\begin{array}{c}0.1885^{* *} \\
(2.54)\end{array}$ & $\begin{array}{c}1.1626^{* *} \\
(2.44)\end{array}$ & $\begin{array}{c}1.2600 * * \\
(2.08)\end{array}$ & $\begin{array}{l}1.4616 \\
(1.35)\end{array}$ \\
\hline $\begin{array}{r}\Delta(\text { Pre-Tax } \\
\text { Interest })\end{array}$ & $\begin{array}{c}0.0000 \\
(0.01)\end{array}$ & $\begin{array}{c}0.0013 \\
(1.03)\end{array}$ & $\begin{array}{c}0.0689 * \\
(1.66)\end{array}$ & $\begin{array}{c}-0.0128^{*} \\
(-1.80)\end{array}$ & $\begin{array}{c}-0.0071 \\
(-1.00)\end{array}$ & $\begin{array}{c}-0.1523 \\
(-0.49)\end{array}$ \\
\hline $\begin{array}{r}\Delta \text { (Income } \\
\text { to Sales) }\end{array}$ & $\begin{array}{c}0.3829 \\
(0.52)\end{array}$ & $\begin{array}{c}0.3276 \\
(0.36)\end{array}$ & $\begin{array}{c}-2.0354 \\
(-0.81)\end{array}$ & $\begin{array}{c}1.8716 \\
(1.52)\end{array}$ & $\begin{array}{l}1.7968 \\
(1.47)\end{array}$ & $\begin{array}{c}25.9123 \\
(1.50)\end{array}$ \\
\hline $\begin{array}{l}\Delta \text { (LT Debt } \\
\text { to Assets) }\end{array}$ & $\begin{array}{c}0.6014 \\
(0.91)\end{array}$ & $\begin{array}{c}0.7186 \\
(0.84)\end{array}$ & $\begin{array}{l}3.2870 \\
(1.45)\end{array}$ & $\begin{array}{c}-2.2788 \\
(-1.37)\end{array}$ & $\begin{array}{c}-1.9567 \\
(-0.94)\end{array}$ & $\begin{array}{c}-2.8967 \\
(-0.22)\end{array}$ \\
\hline $\begin{array}{r}\Delta \text { (Debt to } \\
\text { Capital) }\end{array}$ & $\begin{array}{c}-1.1563 \\
(-1.43)\end{array}$ & $\begin{array}{c}-1.6063 \\
(-1.56)\end{array}$ & $\begin{array}{l}1.3292 \\
(0.66)\end{array}$ & $\begin{array}{l}1.5568 \\
(0.79)\end{array}$ & $\begin{array}{l}1.5662 \\
(0.76)\end{array}$ & $\begin{array}{c}3.6969 \\
(0.34)\end{array}$ \\
\hline$\Delta($ Sdret $)$ & $\begin{array}{c}-0.1936^{* *} \\
(-2.35)\end{array}$ & $\begin{array}{c}-0.1535 \\
(-1.54)\end{array}$ & $\begin{array}{c}-0.3298 * \\
(-1.76)\end{array}$ & $\begin{array}{c}-0.0613 \\
(-0.50)\end{array}$ & $\begin{array}{c}0.2952 * * \\
(2.13)\end{array}$ & $\begin{array}{c}-0.3478 \\
(-0.75)\end{array}$ \\
\hline$\Delta$ (T-note) & $\begin{array}{c}0.5761 * * * \\
(9.76)\end{array}$ & $\begin{array}{c}0.5794 * * * \\
(8.39)\end{array}$ & $\begin{array}{c}0.1961 \\
(0.86)\end{array}$ & $\begin{array}{c}1.8583^{* * * *} \\
(7.21)\end{array}$ & $\begin{array}{c}1.5240^{* * *} \\
(5.01)\end{array}$ & $\begin{array}{c}2.5585^{* * * *} \\
(2.67)\end{array}$ \\
\hline$\Delta$ (Term slope) & $\begin{array}{c}0.5430 * * * \\
(6.39)\end{array}$ & $\begin{array}{c}0.6497 * * * \\
(6.48)\end{array}$ & $\begin{array}{c}-0.2345 \\
(-0.63)\end{array}$ & $\begin{array}{c}2.9444 * * * \\
(8.46)\end{array}$ & $\begin{array}{c}2.5503^{* * * *} \\
(6.47)\end{array}$ & $\begin{array}{c}4.5634 * * * \\
(3.34)\end{array}$ \\
\hline$\Delta$ (Eurodollar) & $\begin{array}{c}0.9973 * * * \\
(8.51)\end{array}$ & $\begin{array}{c}1.0976^{* * *} \\
(7.77)\end{array}$ & $\begin{array}{c}0.6226^{*} \\
(1.94)\end{array}$ & $\begin{array}{c}2.6685^{* * * *} \\
(5.77)\end{array}$ & $\begin{array}{c}3.1532 * * * \\
(4.99)\end{array}$ & $\begin{array}{c}2.0808^{*} \\
(1.87)\end{array}$ \\
\hline Constant & $\begin{array}{c}0.1613^{* * * *} \\
(2.68)\end{array}$ & $\begin{array}{c}0.2132^{* * * *} \\
\quad(3.06)\end{array}$ & $\begin{array}{l}0.0505 \\
(0.20)\end{array}$ & $\begin{array}{c}1.0001^{* * * *} \\
(6.22)\end{array}$ & $\begin{array}{c}1.3306^{* * * *} \\
(7.57)\end{array}$ & $\begin{array}{l}1.0855 \\
(1.23)\end{array}$ \\
\hline Observations & 1,828 & 1,546 & 282 & 1,064 & 781 & 283 \\
\hline Adj. R-sq & 0.521 & 0.545 & 0.853 & 0.718 & 0.785 & 0.858 \\
\hline
\end{tabular}




\section{Table 11: Regression Results: Asset and Financing Decompositions}

Yield spread changes are regressed on variables obtained from a balance sheet decomposition of asset growth into an investment aspect and a financing aspect. The investment decomposition defines total assets as the sum of: (1) Cash ( $\Delta$ Cash: Compustat \#1), (2) Noncash current assets ( $\Delta$ CurAsst: Compustat \#4 - Compustat \#1), (3) Property, plant and equipment ( $\triangle$ PPE: Compustat \#8), (4) Investment and advances ( $\triangle$ IvA: Compustat \#31 +Compustat \#32), (5) Intangible Assets ( $\Delta$ Intan: Compustat \#33), and (6) Other assets ( $\Delta$ OthAssets: $\Delta$ Total assets- $\Delta$ Cash- $\Delta$ CurAsst- $\Delta$ PPE- $\Delta$ IVA- $\Delta$ Intan). The financing decomposition defines total assets as the sum of: (1) Retained earnings ( $\triangle$ RE: Compustat \#36), (2) Stock ( $\Delta$ Stock: Compustat \#130 + Compustat \#60 + Compustat \#38 - Compustat \#36), (3) Debt ( $\Delta$ Debt: Compustat \#9 + Compustat \#34), Operating liabilities ( $\Delta$ OpLiab: $\Delta$ Total liabilities- $\Delta$ Debt) and others liabilities and shareholders' equity $((\Delta$ OthLS: $\Delta$ Total assets- $\Delta$ RE- $\Delta$ Stock- $\Delta$ Debt- $\Delta$ OpLiab). T-statistics are presented in parentheses. $*, * *$ or $* * *$ signifies significance at the $10 \%, 5 \%$, or $1 \%$ level, respectively.

\begin{tabular}{|c|c|c|c|c|c|c|c|c|c|c|c|}
\hline \multicolumn{12}{|c|}{ Panel A. Full Sample } \\
\hline Constant & $\Delta$ Cash & $\Delta$ CurAsst & $\triangle \mathrm{PPE}$ & $\Delta \mathrm{IvA}$ & $\Delta \operatorname{InTan}$ & $\Delta$ OthAssets & $\Delta \mathrm{RE}$ & $\Delta$ Stock & $\Delta$ Debt & $\Delta$ OpLiab & $\Delta$ OthLS \\
\hline $0.3096^{* * * *}$ & $-1.1472^{* * * *}$ & . & . & . & . & . & . & . & . & . & . \\
\hline$(11.15)$ & $(-3.51)$ & & . & . & . & . & . & . & . & . & . \\
\hline $0.2674 * * *$ & . & $1.9731^{* * *}$ & . & . & . & . & . & . & . & . & . \\
\hline$(16.02)$ & . & $(5.17)$ & & . & . & . & . & . & . & . & . \\
\hline $0.2191 * * *$ & . & . & $0.7723 * * *$ & . & . & . & . & . & . & . & . \\
\hline$(12.00)$ & . & . & (3.35) & & . & . & . & . & . & . & . \\
\hline $0.2300^{* * * *}$ & . & . & . & 2.8060 *** & . & . & . & . & . & . & . \\
\hline$(12.12)$ & . & . & . & (3.89) & . & . & . & . & . & . & . \\
\hline $0.2525^{* * *}$ & . & . & . & . & $0.7028 * * *$ & . & . & . & . & . & . \\
\hline$(15.22)$ & . & . & . & . & (3.45) & & . & . & . & . & . \\
\hline $0.2394 * * *$ & . & . & . & . & . & $-0.3703 * * *$ & . & . & . & . & . \\
\hline$(13.65)$ & . & . & & & . & $(-5.27)$ & . & . & . & . & . \\
\hline $0.3475^{* * * *}$ & $-0.8169 * *$ & $1.4877 * * *$ & $0.5225^{* *}$ & $2.8043^{* * * *}$ & 0.1834 & $-0.4265 * * *$ & . & . & . & . & . \\
\hline$(13.26)$ & $(-2.45)$ & (3.29) & $(2.04)$ & (3.87) & $(0.73)$ & $(-6.01)$ & & . & . & . & . \\
\hline $0.2178 * * *$ & . & . & . & . & . & . & 0.2653 & . & . & . & . \\
\hline$(10.71)$ & . & . & . & . & . & . & $(1.15)$ & & . & . & . \\
\hline $0.2589 * * *$ & . & . & . & . & . & . & . & 0.1440 & . & . & . \\
\hline (15.74) & . & . & . & . & . & . & . & $(0.76)$ & . & . & . \\
\hline $0.2481^{* * *}$ & . & . & . & . & . & . & . & . & $1.4859^{* * *}$ & . & . \\
\hline$(13.02)$ & . & . & . & . & . & . & . & . & (4.14) & . & . \\
\hline $0.2117^{*} * *$ & . & . & . & . & . & . & . & . & . & $1.7013 * * *$ & . \\
\hline (10.88) & . & . & . & . & . & . & . & . & . & (4.79) & . \\
\hline $0.2639 * * *$ & . & . & . & . & . & . & . & . & . & . & -0.3707 \\
\hline (14.46) & . & . & . & . & . & . & . & & . & & $(-0.79)$ \\
\hline $0.1870 * * *$ & . & . & . & . & . & . & $-1.0211 * * *$ & 0.3068 & 1.7483 *** & $2.3519 * * *$ & $-1.2889^{*}$ \\
\hline$(8.27)$ & . & . & . & . & . & . & $(-2.93)$ & $(1.17)$ & $(4.27)$ & (4.56) & $(-1.87)$ \\
\hline
\end{tabular}




\begin{tabular}{|c|c|c|c|c|c|c|c|c|c|c|c|}
\hline \multicolumn{12}{|c|}{ Panel B. Positive Asset Growth Sample } \\
\hline Constant & $\Delta$ Cash & $\Delta$ CurAsst & $\triangle \mathrm{PPE}$ & $\Delta \mathrm{IvA}$ & $\Delta \operatorname{InTan}$ & $\Delta$ OthAssets & $\Delta \mathrm{RE}$ & $\Delta$ Stock & $\Delta$ Debt & $\Delta$ OpLiab & $\Delta$ OthLS \\
\hline $0.3379 * * *$ & $-1.0649 * * *$ & . & . & . & . & . & . & . & . & . & . \\
\hline (11.63) & $(-3.58)$ & & . & . & . & . & . & . & . & . & . \\
\hline $0.2778^{* * *}$ & . & $2.1514 * * *$ & . & . & . & . & . & . & . & . & . \\
\hline$(17.82)$ & . & (4.40) & . & . & . & . & . & . & . & . & . \\
\hline $0.1969 * * *$ & . & . & $0.2949 *$ & . & . & . & . & . & . & . & . \\
\hline$(9.42)$ & . & . & $(1.81)$ & & . & . & . & . & . & . & . \\
\hline $0.2462 * * *$ & . & . & . & $1.7576 * *$ & . & . & . & . & . & . & . \\
\hline$(14.15)$ & . & . & . & $(2.17)$ & . & . & . & . & . & . & . \\
\hline $0.2562 * * *$ & . & . & . & . & $0.3740 * *$ & . & . & . & . & . & . \\
\hline$(16.92)$ & . & . & . & . & $(2.40)$ & & . & . & . & . & . \\
\hline $0.2474 * * *$ & . & . & . & . & . & $-0.5119 * * *$ & . & . & . & . & . \\
\hline$(15.61)$ & & & & & . & $(-6.82)$ & & . & . & . & . \\
\hline $\begin{array}{c}0.3876^{* * * *} \\
(1458)\end{array}$ & $\begin{array}{c}-0.6298 * * \\
(-204)\end{array}$ & $2.2449^{* * *}$ & $\begin{array}{l}-0.0516 \\
(-029)\end{array}$ & $2.0703 * *$ & $\begin{array}{l}-0.0968 \\
(-0.49)\end{array}$ & $-0.5498^{* * * *}$ & . & . & . & . & . \\
\hline $\begin{array}{c}(14.58) \\
0.1976 * * *\end{array}$ & $\begin{array}{c}(-2.04) \\
.\end{array}$ & $(3.92)$ & $(-0.29)$ & $(2.52)$ & $(-0.49)$ & $(-7.38)$ & 0.1282 & $\cdot$ & . & . & . \\
\hline$(7.32)$ & . & . & . & . & . & . & $(0.54)$ & & . & . & . \\
\hline $0.2233 * * *$ & . & . & . & . & . & . & . & $0.4713 * *$ & . & . & . \\
\hline (9.97) & . & . & . & . & . & . & . & (2.36) & . & . & . \\
\hline $0.2629 * * *$ & . & . & . & . & . & . & . & . & $0.9440 * *$ & . & . \\
\hline$(17.60)$ & . & . & . & . & . & . & . & . & $(2.51)$ & . & . \\
\hline $0.2547 * * *$ & . & . & . & . & . & . & . & . & . & $0.8684 * *$ & . \\
\hline$(12.37)$ & . & . & . & . & . & . & & . & . & $(2.27)$ & \\
\hline $0.2849 * * *$ & . & . & . & . & . & . & . & . & . & . & $-1.3196 * * *$ \\
\hline (16.51) & . & . & . & . & . & . & . & . & . & . & $(-2.58)$ \\
\hline $0.2255^{* * *} *$ & . & . & . & . & . & . & $-0.7674 * *$ & $0.8055^{* * *}$ & $1.5583 * * *$ & 1.0970 ** & $-1.4196 * *$ \\
\hline$(10.51)$ & . & . & . & . & . & . & $(-2.23)$ & (3.39) & (4.13) & (2.01) & $(-1.97)$ \\
\hline
\end{tabular}




\begin{tabular}{|c|c|c|c|c|c|c|c|c|c|c|c|}
\hline \multicolumn{12}{|c|}{ Panel C. Negative Asset Growth Sample } \\
\hline Constant & $\Delta$ Cash & $\Delta$ CurAsst & $\triangle \mathrm{PPE}$ & $\Delta \mathrm{IvA}$ & $\Delta$ InTan & $\Delta$ OthAssets & $\Delta \mathrm{RE}$ & $\Delta$ Stock & $\Delta$ Debt & $\Delta$ OpLiab & $\Delta$ OthLS \\
\hline $0.2077 * * *$ & $-6.0798 * * *$ & & . & . & . & . & . & . & . & . & . \\
\hline (2.77) & $(-5.92)$ & & . & . & . & . & . & . & . & . & . \\
\hline $0.1900 * * *$ & . & $2.9990 * * *$ & . & . & . & . & . & . & . & . & . \\
\hline (3.57) & . & (2.81) & . & . & . & . & . & . & . & . & . \\
\hline $0.2679 * * *$ & . & . & $4.7555^{* * *}$ & . & . & . & . & . & . & . & . \\
\hline (5.14) & . & & (3.73) & & . & . & . & . & . & . & . \\
\hline $0.3177 * * *$ & . & . & . & $4.1554 * *$ & . & . & . & . & . & . & . \\
\hline$(5.71)$ & . & . & . & (2.28) & & . & . & . & . & . & . \\
\hline $0.2489 * * *$ & . & . & . & . & $4.3068 * * *$ & . & . & . & . & . & . \\
\hline (4.75) & . & . & . & . & (3.27) & & . & . & . & . & . \\
\hline $0.3061 * * *$ & . & . & . & & . & $0.5354 * * *$ & . & . & . & . & . \\
\hline$(5.82)$ & . & & . & . & . & $(2.72)$ & . & . & . & . & . \\
\hline 0.1159 & $-4.2245^{* * *}$ & $1.8740 *$ & $3.7219 * * *$ & 3.5903* & $3.3668 * *$ & $0.5817 * * *$ & . & . & . & . & . \\
\hline (1.57) & $(-3.63)$ & $(1.67)$ & (2.84) & $(1.93)$ & (2.48) & (2.93) & . & . & . & . & . \\
\hline $0.3162 * * *$ & . & . & . & . & . & . & -1.6151 & . & . & . & . \\
\hline (4.43) & . & . & . & . & . & . & $(-1.19)$ & & . & . & . \\
\hline $0.2484 * * *$ & . & . & . & . & . & . & . & $-1.8055^{* * *}$ & . & . & . \\
\hline (4.61) & . & . & . & . & . & . & . & $(-3.18)$ & & . & . \\
\hline $0.1925^{* * *}$ & . & . & . & . & . & . & . & . & 0.7895 & . & . \\
\hline (3.36) & . & . & . & . & . & . & . & . & $(0.89)$ & . & . \\
\hline $0.2013 * * *$ & . & . & . & . & . & . & . & . & . & $7.4112 * * *$ & . \\
\hline$(3.26)$ & . & . & . & . & . & . & . & . & . & (4.78) & . \\
\hline $0.2035^{* * *}$ & . & . & . & . & . & . & . & . & . & . & $2.7146 * * *$ \\
\hline (3.59) & . & . & . & . & . & . & . & . & & & (2.58) \\
\hline $0.3650 * * *$ & . & . & . & . & . & . & $-2.4822 *$ & -0.8878 & $2.0696^{*}$ & $8.1579 * * *$ & -0.3292 \\
\hline (6.77) & . & & . & . & . & . & $(-1.77)$ & $(-1.13)$ & $(1.83)$ & (5.12) & $(-0.14)$ \\
\hline
\end{tabular}




\section{Table 12: Asset Growth and Bond Performance}

We perform panel regression on the asset growth effect on bond return. In column (1) to column (4), the dependent variable is the excess return of corporate bonds over one year treasury rate. In column (5), the dependent variables is the yield change effect component of bond return. In column (6), the dependent variable is the yield effect component of bond return. We control for firm characteristics: asset growth rate, leverage, income to sales and market to book (M/B) ratio. We also control for bond characteristics: bond ratings, years to maturity, and yield to maturity. More details on the construction of these variables are provided in the Appendix. T-statistics are presented in parentheses. The issuer is the fixed effect. *, $* *$ or $* * *$ signifies significance at the $10 \%, 5 \%$, or $1 \%$ level, respectively.

\begin{tabular}{|c|c|c|c|c|c|c|}
\hline & $\begin{array}{c}\text { (1) } \\
\text { Return }\end{array}$ & $\begin{array}{c}(2) \\
\text { Return }\end{array}$ & $\begin{array}{c}(3) \\
\text { Return }\end{array}$ & $\begin{array}{c}(4) \\
\text { Return }\end{array}$ & $\begin{array}{c}(5) \\
\text { Price Change }\end{array}$ & $\begin{array}{c}(6) \\
\text { Current Yield }\end{array}$ \\
\hline Asset Growth & $\begin{array}{c}-0.0256 * * * \\
(-3.21)\end{array}$ & $\begin{array}{c}-0.0274 * * * \\
(-4.00)\end{array}$ & $\begin{array}{c}-0.0216 * * * \\
(-2.82)\end{array}$ & $\begin{array}{c}-0.0233 * * * \\
(-3.41)\end{array}$ & $\begin{array}{c}-0.0230 * * * \\
(-3.67)\end{array}$ & $\begin{array}{c}-0.0002 \\
(-0.19)\end{array}$ \\
\hline Leverage & & & $\begin{array}{c}0.0602 * * \\
(2.45)\end{array}$ & $\begin{array}{c}0.0499 * * \\
(2.08)\end{array}$ & $\begin{array}{c}0.0513 * * \\
(2.40)\end{array}$ & $\begin{array}{c}-0.0010 \\
(-0.28)\end{array}$ \\
\hline Income to Sales & & & $\begin{array}{c}-0.0392^{*} \\
(-1.84)\end{array}$ & $\begin{array}{c}-0.0675^{* * *} \\
(-3.68)\end{array}$ & $\begin{array}{c}-0.0564 * * * \\
(-3.45)\end{array}$ & $\begin{array}{c}-0.0120 * * * \\
(-3.63)\end{array}$ \\
\hline $\mathrm{M} / \mathrm{B}$ & & & $\begin{array}{c}-0.0007 * * \\
(-2.17)\end{array}$ & $\begin{array}{c}-0.0005^{*} \\
(-1.70)\end{array}$ & $\begin{array}{c}-0.0004 * \\
(-1.65)\end{array}$ & $\begin{array}{c}-0.0000 \\
(-1.55)\end{array}$ \\
\hline Rating & & $\begin{array}{c}-0.0098 * * * \\
(-6.40)\end{array}$ & & $\begin{array}{c}-0.0086 * * * \\
(-5.59)\end{array}$ & $\begin{array}{c}-0.0068 * * * \\
(-5.03)\end{array}$ & $\begin{array}{c}-0.0018 * * * \\
(-6.48)\end{array}$ \\
\hline Maturity & & $\begin{array}{c}0.0015 * * * \\
(9.07)\end{array}$ & & $\begin{array}{c}0.0015 * * * \\
(9.12)\end{array}$ & $\begin{array}{c}0.0013 * * * \\
(8.40)\end{array}$ & $\begin{array}{c}0.0002 * * * \\
(8.67)\end{array}$ \\
\hline Yield & & $\begin{array}{c}-0.0087 * * * \\
(-8.84)\end{array}$ & & $\begin{array}{c}-0.0088 * * * \\
(-8.89)\end{array}$ & $\begin{array}{c}-0.0095 * * * \\
(-9.12)\end{array}$ & $\begin{array}{c}0.0006 * * * \\
(5.11)\end{array}$ \\
\hline Constant & $\begin{array}{c}0.0776 * * * \\
(147.95)\end{array}$ & $\begin{array}{c}0.2490 * * * \\
(10.92)\end{array}$ & $\begin{array}{c}0.0659 * * * \\
(6.61)\end{array}$ & $\begin{array}{c}0.2303 * * * \\
(9.06)\end{array}$ & $\begin{array}{c}0.1434 * * * \\
(6.35)\end{array}$ & $\begin{array}{c}0.0866 * * * \\
(18.92)\end{array}$ \\
\hline Observations & 19,956 & 19,956 & 19,956 & 19,956 & 19,956 & 19,956 \\
\hline R-squared & 0.084 & 0.181 & 0.088 & 0.184 & 0.185 & 0.673 \\
\hline
\end{tabular}




\title{
Manuscript 2 \\ Prepared for submission to Journal of Banking and Finance. \\ Too-Big-to-Fail: The Value of Implicit Government Guarantee
}

\begin{abstract}
Following the 2008 financial crisis and the government bailout of troubled companies, Too-Big-to-Fail became a standard expression to name a free protection of Wall Street by tax-payers' money. We offer a novel approach to estimate the value of the implicit government guarantee by combining the contingent claim pricing with the likelihood of the government intervention. We find that the cost of this implicit protection on average is about $\$ 13$ million per company, per year, and it rises to about $\$ 24$ million if the government is assumed to intervene with certainty. The funding costs for both small and large banks are negatively related to the value of the implicit government guarantee. Moreover, we show that the spread of the funding costs of small banks over large banks is strongly associated with the value of the implicit government guarantee, especially after the crisis.
\end{abstract}




\section{Too-Big-to-Fail: The Value of Implicit Government Guarantee}

\section{Introduction}

Shedding some light on the 2008 financial crisis, Sorkin (2009) chronicles the story from the beginning of the crisis to the Troubled Asset Relief Program (TARP) and popularizes the concept of "Too Big to Fail" (TBTF). While saving the financial system, TARP was controversial as the cost of the bailout was mainly supported by the US tax payers. The idea of TBTF suggests that large companies enjoy a guarantee that they will be rescued by the government in a bankruptcy situation. As written by Bloomberg editorial board:

"On television, in interviews and in meetings with investors, executives of the biggest U.S. banks -- JPMorgan Chase \& Co. Chief Executive Jamie Dimon -- make the case that size is a competitive advantage. It helps them lower costs and vie for customers on an international scale. Limiting it, they warn, would impair profitability and weaken the country's position in global finance.

So what if we told you that, by our calculations, the largest U.S. banks aren't really profitable at all? What if the billions of dollars they allegedly earn for their shareholders were almost entirely a gift from U.S. taxpayers?"1

There is a common agreement that such an implicit guarantee exists and its cost may be justified due to the potential impact on the overall economy in case of the collapse of the financial system. At the same time, the implicit government guarantee

\footnotetext{
${ }^{1}$ From of Bloomberg View's Editorials: Why Should Taxpayers Give Big Banks $\$ 83$ Billion a Year?, February $20^{\text {th }}, 2013$
} 
reduces investors' perception about the risk of the financial institution and their expected losses. It also leads to unfair competition due to lower cost of funds, increased risk taking by TBTF institutions and increased potential financial burden on the government. Policy makers have an intention to curb the value of the implicit government guarantee (Schich and Aydin (2014)) which creates a need for having a robust way of measuring it.

The contribution of this article is twofold. First, we propose a novel way to measure the value of the implicit government guarantee. Using our approach we find a confirmation for the above Bloomberg editorial board view that the estimate of the implicit government protection can go beyond billions of dollars for some of the largest companies. Since the implicit government guarantee may potentially involve transfer of billions of dollars from the government to the bailed-out companies, the ability to estimate it remains an important public policy concern. Second, we investigate the relationship between the implicit government guarantee and the funding costs of small and large banks. The funding costs are often used as a proxy for the TBTF effect. Strong association between the spread of funding costs of small banks over large banks with our estimate of the implicit government guarantee serves as an additional confirmation of the validity of our model.

Quantifying the value of the implicit government guarantee has generated a considerable interest in the years following the financial crisis. The more common approaches of assessing the TBTF or the value of implicit government guarantee can be split into three groups: i) The funding cost approach; ii) The CDS-based approach; iii) The contingent claims approach. 
The funding cost approach argues that the TBTF institutions enjoy lower costs of funds due to the implicit government guarantee. The implicit government guarantee is estimated as a reduction in the costs of funds that the TBTF institutions have compared to the costs of funds without the government guarantee. A number of papers (for example, Baker and McArthur (2009) and Li, Qu, and Zhang (2011)) estimate the reduction in the funding costs as the difference in the cost of funds of small and large (TBTF) financial institutions. It is assumed that only the large banks will be supported by the government in case of default. Several other papers (see, for example, Noss and Sowerbutts (2012), Ueda and di Mauro (2013), Lambert et al. (2014), and Schich, Bijlsma and Mocking (2014)) estimate the reduction in the funding costs based on credit ratings. Credit rating agencies produce two credit ratings - an "individual" credit rating designed to assess institution's strength on a stand-alone basis and a "support" rating which incorporates the probability that the institution will receive government support. The reduction in the funding costs in this case is estimated as the difference in the cost of funds based on higher "individual" rating and actual "support" rating. The implicit government guarantee is then calculated by multiplying the difference in the funding costs by the assets of the TBTF banks. The main drawback of the first approach is that it doesn't control for the relative risk of different financial institutions and doesn't take into consideration the likelihood of receiving government support. The rating-based approach avoids these problems, it is easy to implement, and the required data is readily available, but it suffers from being subjective and relying on credit rating agency judgement regarding creditworthiness of the company. In the aftermath of the financial 
crisis of 2007-2009, credit rating agencies have been heavily criticized for producing inaccurate credit ratings.

The CDS-based approach compares the difference between observed CDS spreads and modelled fair-value CDS spreads (FVS) calculated from the equity price information. Observed CDS spread is an indicator of the company's perceived risk of default and it reflects the likelihood of government intervention and the size of government support in case of distress. The CDS-based approach usually assumes that equity holders are wiped out if company defaults. It implies that equity prices contain only information about the probability of company's default and disregard the possibility of government intervention. Therefore, the FVS computed based on equity prices do not include the government guarantee. Several papers (see, for example, Schweikhard and Tsesmelidakis (2012) and Lambert et al. (2014)) use Merton (1974) model to estimate FVS, whereas Li, Qu, and Zhang (2011) use some proprietary model for this purpose. The difference between the FVS and the observed CDS spreads is then used as a measure of the implicit government guarantee. The biggest drawback of this method is data availability. The CDS data is only available for large financial institutions, which limits the data sample. Another potential problem with this approach is the underlying model assumptions used to compute FVS, including the assumption that equity holders are not bailed out.

The contingent claims approach typically relies on Merton's (1974) model. It is assumed that a firm has two types of claims - single homogeneous class of debt and the residual claim, equity. The implicit government guarantee is estimated by modeling the firm's assets. The firm defaults when the value of the firm's assets falls below some 
threshold (default barrier) at a future time, $T$. Under the Merton's model the firm cannot default before time $T$. In case of default, the bondholders take over the firm and the shareholders get nothing. The value of the implicit government guarantee is computed as a put option on the firm's assets with the strike price equal to the default barrier at some future time. It is assumed to be the sum necessary to restore the value of assets to the debt threshold. Most of the studies that use the contingent claims approach calculate the implicit government guarantee as an aggregate subsidy for all banks (see, for example, Noss and Somerbutts (2012), or Oxera (2011)). One potential problem related to this approach is the need to estimate the asset value and the asset volatility which are unobservable and should be inferred from the equity market information. The techniques used in the literature estimate the asset value and volatility by simultaneously solving the system of two equations with two unknowns (see, for example, Lucas and McDonald (2009)), some papers rely on oversimplifying assumptions (for example, Noss and Somerbutts (2012) and Oxera (2011) assume that equity constitutes 6\% of total assets) or use complex and resource-intensive techniques (for example, Jobst and Gray (2013)). Using the contingent claim approach implicitly assumes that the government will intervene with certainty. However, on an individual basis, as evidence by the collapse of the Lehman Brothers, this intervention may fail to materialize. Therefore, it is necessary to take into account the likelihood of the government intervention for a given firm. The framework for estimating the likelihood of the government intervention is provided by Beliaeva, Khaksari and Tsafack (2015) who estimate it using the size and the finance industry membership of the company. 
In this paper we combine the contingent claim approach with the likelihood of the government intervention to provide an appropriate and robust measure of the implicit government guarantee as the expected value of the contingent claim. ${ }^{2}$ This is simply the product of the probability of the government intervention and the value of the put option. We find that the cost of the government protection in our sample is, on average, about $\$ 24.5$ million per company, per year, and it drops to $\$ 13.4$ million when we incorporate the fact that the government may not intervene. Our estimates are also consistent with the Bloomberg View's editorials, as we find that the value of the implicit government guarantee can go beyond billions of dollar for very large banks with trillions of dollar in assets and debts. The value of the implicit government guarantee sharply increases after the 2008 financial crisis.

Our empirical analysis reveals a consistently inverse relationship between funding costs and the value of the implicit government guarantee. This inverse relationship means that the decrease in the funding costs is associated with an increase in the value of the government guarantee for both large and small companies. Furthermore, we find that the spread in funding costs of small banks over large banks and the implicit government guarantee are positively related. In fact, the increase in the difference between the funding costs of small banks and large banks is often considered as a proxy for the too-big-to-fail premium. Therefore, the positive relationship confirms this intuition and reinforces our confidence in the way we estimate the value of the implicit government guarantee. Investigating potential structural break for the period

\footnotetext{
${ }^{2}$ To compute the contingent claim value, we derive an easily implementable solution for the asset value and asset volatility, which involves solving only one equation with one unknown instead of solving a system of two highly nonlinear equations at once.
} 
after the crisis mostly confirms our results. The relationship between the funding cost spread and the implicit government guarantee is strong and positive both before and after the crisis for bank holding company data. For the FDIC data the results are only strong and positive after the crisis. Before the crisis the relationship is inverse which can be attributed to the FDIC insurance effect.

The remainder of the paper is organized as follows. Section 2 describes our methodology and the data set used to estimate the implicit government guarantee. Section 3 describes the methodology, the data, and the variables used for analyzing the relationship between our measures of the implicit government guarantee and funding costs. Section 4 presents and summarizes our empirical findings, and section 5 concludes.

\section{Estimation of the Value of the Implicit Government Guarantee}

\subsection{Definition}

We define the value of the implicit government guarantee as the expected value of the government intervention to rescue the distressed firm. The value of the implicit government guarantee for company $i$ is computed as:

$$
E v_{g, i}=\pi_{i} \times v_{g, i}
$$

Where, $\pi_{i},-$ the probability of the government intervention for company $i$;

$v_{g, i}-$ the value of the government subsidy given that intervention will happen with certainty for company $i$.

\subsection{Estimating the Probability of the Government Intervention $\left(\pi_{i}\right)$ :}

Following Beliaeva, Khaksari and Tsafack (2015), we use a logit model to estimate the probability that the government will step in and rescue a company in 
distress. In our logit model we use the finance industry indicator, the firm size, and the interaction term between these two variables as explanatory variables. The logit model provides a simple way to describe the relationship between several explanatory variables and a binary dependent variable. We apply our model to an extensive dataset of 1571 bankrupt and bailed out companies between 2000 and 2015. The dependent variable in the logit model estimates the probability that the government will step in and rescue a company in distress. It is defined as follows:

$$
\text { Bailout }_{i}=\left\{\begin{array}{l}
1, \text { if } \text { firm is rescued by the goverment } \\
0, \quad \text { otherwise }
\end{array}\right.
$$

The logit model is then specified as follows:

$$
P\left(\text { Bailout }_{i}\right)=F\left(\beta_{0}+\beta_{1} \text { lgasset }+\beta_{2} \text { Dum }_{\text {Fin }}+\beta_{3} \text { lgasset } * \text { Dum }_{\text {Fin }}\right)
$$

Where, $F(\cdot) \quad-\quad$ the logit function;

lgasset, -
$\begin{aligned} & \text { the natural logarithm of the total assets; } \\ & \text { the dummy },-\end{aligned}$
belongs to the finance industry or not;
lgasset $*$ Dum $_{\text {Fin }}-$ the interaction term between the log of the total assets and the finance industry membership.

\subsection{The Government Guarantee Data and Results}

The data that we use to estimate the implicit government guarantee comes from several major sources: SDC Platinum database, TARP database and ProPublica website. SDC Platinum database includes all US public companies with \$10 million or more in assets that file for Chapter 11 bankruptcy protection. We compile a broad sample of Chapter 11 bankruptcy filings spanning the years 2000 through 2015 (SDC coverage begins in 1980). We exclude firms with reported assets under $\$ 100$ million. 
The list of bailout firms is obtained from the ProPublica's website and the TARP database.

\section{[Insert Table 1 Here]}

Panel A of Table 1 summarizes the number of bailout and bankrupt firms in our sample. We have a total of 1,247 bankruptcy cases, including 175 finance firms, and 324 bailout firms, including 304 finance firms. Panel B of Table 1 provides summary statistics for the variables used in the estimation of the probability of the government intervention. The average of the total assets is $\$ 12$ billion. We normalize the total assets by taking the natural logarithm of the total assets (lgasset hereafter). The average of lgasset is 6.79 with the standard deviation of 1.53. Panel C of Table 1 shows the correlation coefficients among these variables. We observe a 0.685 correlation between the finance industry dummy variable and the bailout dummy variable and 0.36 correlation between the log of total assets and the bailout dummy variable.

\section{[Insert Table 2 Here]}

We analyze four different model specifications of logit regression. In model 1 and model 2 we estimate the effects of the financial industry (finance dummy) and the firm size (log of total assets) on the probability of the government intervention, respectively. We include both variables in model 3. To examine the interaction effect, in model 4 we include an additional interaction variable between the finance industry dummy and the log of the total assets. The results of the logit regression estimation for four model specifications are presented in Table 2. All of the parameter estimates are significant at a $1 \%$ level across all models. Although the size and the financial industry 
membership are the two main factors explaining the probability of the government intervention, the addition of the interaction variable between the firm size and the finance industry dummy increases the explanatory power of the model. In fact, model 4 is the best fitting model out of the four model specifications as evidenced by the lowest AIC criteria of 733.67 and the highest Pseudo $R^{2}$ of $64.03 \%$. Therefore, we choose Model 4 specification to estimate the probability of the government intervention for all firms in our full sample. ${ }^{3}$ The negative sign for the coefficient of the interaction variable seems counterintuitive as the TBTF is mostly related to the financial institutions. A straightforward interpretation of the negative sign is that while the size matters for a bailout of any firm, it is more important for non-finance firms relative to finance firms. This result can be justified by the fact that there is a strong correlation between credit risks of large and small banks. This is especially true for our sample. The TARP program for the bailout of the financial system included both very large banks as well as small banks. In contrast, non-finance companies' bailout had more homogeneity: firms rescued in 2001 were mostly big airline companies. Therefore, while the firm size matters for a bailout decision, within the financial system, the size effect for individual financial institutions is overshadowed by the risk of the contagion effect. Due to this, the firm's size is not the main driving factor of the bailout decision within the financial industry.

It also worth noticing that our estimation procedure does not include a dummy variable for the crisis period. Although the bailout is related to the economic environment, including a variable indicator for the crisis period will introduce some

\footnotetext{
${ }^{3}$ Note that the data sample used to estimate the probability of the government intervention involved only bailout companies or those that went bankrupt.
} 
endogeneity in the estimation of the likelihood of the government intervention for a given company. In fact, when TBTF companies are in trouble, it tends to trigger both a crisis and a bailout program. This can be seen in our sample as we have bailouts only during the crisis period, which can give a false impression that a bailout cannot occur without a crisis. In our study we are more interested in the probability of the government intervention for a given firm, even if the company is far from a distress situation. We expect the crisis effect to be captured by the value of the contingent claim.

Using the estimated parameters, we fit the data to the following Logistic function:

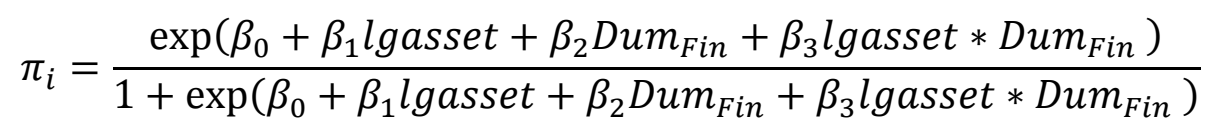

The above equation is used at a company level to derive the likelihood of the government intervention which is then incorporated into the calculation of the value of the implicit government guarantee.

\subsection{Estimating the Value of the Government Subsidy Given Intervention $\left(V_{i}\right)$}

We estimate the value of the government subsidy given that intervention will happen with certainty (i.e. assuming the "full coverage" by the government) using the contingent claims approach of Merton (1974). Under this approach it is assumed that the firm has a simple capital structure consisting of equity and a single homogeneous class of debt. The firm's equity value is modelled as a call option on the firm's assets with the exercise price equal to the firm's default barrier (firm's liabilities). ${ }^{4}$ If at the option's maturity the asset value is less than the strike price, then the option expires

\footnotetext{
${ }^{4}$ This approach is similar to that described in Crosbie and Bohn (2003) and Vassalou and Xing (2004).
} 
worthless, shareholders get nothing and the firm is turned over to the debtholders. The value of the implicit government guarantee is analogous to a put option on the firm's assets with the strike price equal to the default barrier (firm's liabilities). If at option's maturity the asset value is less than the strike price, then the option is in-the-money and the option payoff (i.e. payoff from the government) is equal to the difference between the strike price (the firm's liabilities) and the firm's assets. It is represented as a claim that firms have on the government contingent on their failure, the exercising of which restores their assets to a value necessary to prevent their default. The estimation of the value of the government subsidy is done in two steps:

Step 1. Estimate $V_{A}$ (the value of assets) and $\sigma_{A}$ (the volatility of assets) by solving a system of two equations based on Black and Scholes (1973) and Merton (1974).

Equation 1: The value of equity expressed as a call option on the firm's assets:

$$
\begin{gathered}
V_{E}=V_{A} \times N\left(d_{1}\right)-L \times e^{-r_{f} \tau} \times N\left(d_{2}\right), \\
d_{1} \\
=\frac{\ln \left(\frac{V_{A}}{L}\right)+\left(r_{f}+\frac{1}{2} \sigma_{A}^{2}\right) \tau}{\sigma_{A} \sqrt{\tau}} \\
d_{2}=d_{1}-\sigma_{A} \sqrt{\tau}
\end{gathered}
$$

Where, $V_{A}-\quad$ the value of assets,

$\sigma_{A}-\quad$ the volatility of assets,

$V_{E}-\quad$ the value of equity,

$\sigma_{E}-\quad$ the volatility of equity, 
$L-\quad$ the firm's existing liabilities (senior debt, subordinated debt, preferred equity).

Equation 2: The relationship between the value of equity and the volatility of assets:

$$
V_{E}=\frac{\sigma_{A}}{\sigma_{E}} \times V_{A} \times N\left(d_{1}\right)
$$

Given the equity volatility data, the risk-free rate, the market value of equity, and the face value of debt, it is necessary to solve the system of these two highly non-linear equations to estimate the value of assets and the volatility of assets. We derive an easily implementable solution for the assets value and assets volatility which involves solving only one equation with one unknown. Technical details on the estimation procedure are provided in Appendix A.

Step 2. Compute the value of the implicit government guarantee given intervention as a put option on the firm's assets with the strike price equal to the default barrier (the firm's liabilities).

$$
v_{i}=L \times e^{-r_{f} \tau} \times N\left(-d_{2}\right)-V_{A} \times N\left(-d_{1}\right)
$$

For a given company $i$, this represents the value of the government guarantee given that the intervention will happen with certainty.

\section{Government Guarantee and the Funding Costs}

\subsection{The Model Specification}

It is often assumed that only large financial institutions will be supported by the government in case of default ${ }^{5}$. Therefore, the difference in the costs of funds between

\footnotetext{
${ }^{5}$ This is the premises of the funding cost approach (see, for example, Baker and McArthur (2009) and Li, Qu, and Zhang (2011)).
} 
small and large financial institutions can be thought of as a proxy for the implicit government guarantee. In this section we investigate the relationship between our measure of the value of the implicit government guarantee, $E v_{g}$, and the funding cost variable while also controlling for the GDP growth rate. We use the following model specification:

$$
E v_{g}=\alpha_{0}+\beta \times \text { FundingCost }+\gamma \times \text { GDP Growth }
$$

To investigate the potential change in the relationship between of the value of the implicit government guarantee and the funding cost, we introduce an interaction variable between the funding cost and the crisis indicator as follows.

$$
E v_{g}=\alpha_{0}+\beta \times \text { FundingCost }+\delta \times \text { AfterCrisis } \times \text { FundingCost }+\gamma \times
$$

\section{GDP Growth,}

Where, AfterCrisis - a dummy variable taking a value of one after the crisis and zero otherwise.

To study the relationship between the value of the implicit government guarantee and the funding cost variable, we sort our data sample into two groups by bank size. Following Li, Qu, and Zhang (2011), we define the top 20 in book assets as of December of each year as large banks and the remainder as small banks. We separately analyze the relationship between the implicit government guarantee and the funding costs of large banks, small banks and the difference in the funding costs of small and large banks.

The analysis of the relationship between the implicit government guarantee and the funding cost variable provides an alternative way to assess the robustness of our results. 


\subsection{Funding Cost Measure}

The bank's funding cost, i.e. the interest rate charged by the bank's creditors, depends on the lender's perception of the bank's probability of distress. In other words, the lenders assess the bank's default probability and adjust the interest rate they charge accordingly. There are two ways to obtain data on interest rates and default probabilities for any given bank.

First, interest rates and default probabilities can be extracted from the market data. A popular proxy for the bank's funding cost is a CDS spread, which can also be used to imply the bank's default probability. However, the limitation of this approach is that the CDS data is not widely available for small banks. An alternative source of data on the bank's funding cost and default probability is the bank's balance sheet reports. The data on the bank's interest expense on debt allows to construct proxies of funding costs. Baker and McArthur (2009) use the FDIC data for depository institutions to compare the average cost of funds for large banks against small banks. Since the FDIC data is at the depository firm level, this analysis does not cover the consolidated bank holding company level where additional funding costs may arise. In addition to using funding costs incurred by depository institutions as reported by the FDIC, we construct funding costs using banks' corporate level balance sheet data from COMPUSTAT Bank database.

Following Araten and Turner (2013), we use the cost of deposit as a measure of funding cost. It is defined as a ratio of the total interest expense on interest bearing liabilities to the average total interest bearing liabilities between year $t$ and year $t-1$ : 


$$
\text { Funding Cost }=\frac{\text { Interest Expense on Interest Bearing Liabilities }}{\text { Average total interest bearing liabilities }}
$$

The funding cost measure is computed on a quarterly basis. The interest expense on interest bearing liabilities (i.e. interest bearing debt) includes interest paid on certificates of deposit, savings certificates, saving deposits and time deposits. The average total liabilities are computed as the average of the ending total liabilities of quarter $t$ and the average of the ending total liabilities of quarter $t-4$.

Existing literature has examined alternative measures of funding costs, such as the average funding cost and the interbank funding cost (see, for example, Araten and Turner (2013) and Aymanns, Caceres, Daniel and Schumacher (2016)). However, these two measures may not be appropriate for our study. The average funding cost measure includes payments made to all of the bank's creditors, including both retail and wholesale depositors. As noted by Araten and Turner (2013), the composition of the average funding cost is different for large and small banks, in which large banks have various sources of funds, while small banks largely rely on regular deposits. As a result, the average funding cost of large banks tends to be upward biased due to the mix of funding cost. The interbank funding cost measure is calculated as a ratio of interest expense on federal funds and repos purchased to the average total federal funds and repos purchased during the reporting period. The large banks are more likely to use federal funds and repos for short-term borrowing, while small banks have limited access to them. In fact, the cost of federal funds makes up only $6 \%$ of the overall funding costs of small banks as reported by Araten and Turner (2013). Due to the shortcomings of the alternative funding cost measures, in our study we define the funding cost as the cost of deposit. 


\subsection{Bank Funding Cost Data}

The banking data is obtained from the COMPUSTAT Bank database and the Federal Deposit Insurance Corporation (FDIC). The COMPUSTAT Bank database contains data on all publicly listed US banks and consolidates bank data at bank holding company level. There are 1,440 US listed banks from 2000 to 2015 . The FDIC dataset contains approximately 10,000 US depository institutions over a period of 16 years ranging from 2000 to 2015 . Our data sample is constrained by data availability. For example, if the data is missing for a bank in a specific quarter, we exclude that observation from our data sample. Our final sample consists of 106 listed banks from Compustat and 10,638 depository institutions from FDIC.

\section{[Insert Figure Here]}

To conduct a funding cost analysis of large and small banks over the 2000 to 2015 period, we define large or TBTF banks as the top 20 banks in book assets for each period. ${ }^{6}$ Figure compares the funding cost differences between small and large banks before, during and after the crisis period. Using the NBER business cycle data, the pre-recession period is defined as the one year period before the peak of the recession and the post-recession period is defined as the one year period after the trough of the recession. The recession period starts at the peak of the recession and ends at the trough. The funding cost is calculated as the average of the yearly medians of annualized quarterly funding costs during the designated period. As shown in Figure, the funding cost difference between small BHCs and large BHCs is -30 bps

\footnotetext{
${ }^{6}$ We also look at an alternative definition of large banks: for a given quarter large banks are defined as banks with book asset over $\$ 100$ billion. Such alternative definition does not change our results substantially.
} 
during the pre-crisis period. The funding cost gap increases by 24 bps from -30 bps to -6 bps during the crisis period, suggesting that due to the implicit government guarantee the funding cost for large BHCs decreased more compared to that of the small BHCs. Moreover, large BHCs have an 8 bps funding cost advantage over small BHCs during the one year post crisis period implying that large BHCs continued enjoying the implicit government guarantee after the crisis. Figure 2.1 shows that the funding cost advantages of the large banks continues for 2 years after the trough of the crisis and then it gradually narrows down.

\section{[Insert Figure 2.1 Here]}

For the FDIC banks the funding cost advantage for large banks is even stronger. As Figure shows, the funding cost difference between small and large banks is -11 bps during the pre-crisis period, it increases to 55 bps during the crisis period, and to 89 bps during the one year post crisis period. Figure 2.2 shows that the funding cost advantages of the large banks over the small banks is still big (79 bps) two years after the crisis. Our findings provide strong evidence that the large banks enjoy funding cost benefits associated with the TBTF status.

\section{[Insert Figure 2.2 Here]}

An important point we want to address here is the FDIC insurance effect on the funding cost. The FDIC insurance protects the funds depositors place in banks and saving associations against the losses associated with the failure of the FDIC insured institution. FDIC deposit insurance is backed by the full faith and credit of the United States government. The standard deposit insurance amount is $\$ 250,000$ per depositor, per insured bank, for each account ownership category. In the event of a bank failure, 
FDIC pays insurance to depositors up to the insurance limit. Funding cost is the interest rate charged by the bank's creditors, reflecting lender's perception of the bank's creditworthiness. Thus, the FDIC insurance can potentially lower the funding costs for FDIC insured institutions. The effect should be stronger for small banks because small banks are more likely to attract deposits from ordinary depositors with the deposit amount below the insurance limit while large banks have a large variety of clients with the large variation in deposit amounts. Our finding show that before the crisis small FDIC banks had lower funding costs compared to the large banks which could be partially attributed to the FDIC insurance effect. However, this relationship reversed during and after the crisis. While funding costs decreased for both small and large FDIC banks, the reduction was much bigger for the large FDIC banks resulting in significantly lower costs of funds for the large banks compared to the small banks. This suggests that during and after the crisis the FDIC insurance effect is not significant and it is overpowered by the increase in the value of the implicit government guarantee.

\subsection{Summary statistics}

We provide below the summary statistics for the value of the contingent claim, the expected value of the implicit government guarantee, the leverage, and the funding cost.

\section{[Insert Table 3 Here]}

Panel A provides the descriptive statistics of variables for government guarantee estimation. Panel B and Panel C provide summary statistics of banks' fundamental and funding cost variable from 2000 to 2015 for BHCs and FDIC banks, respectively. Bank fundamental variables include total assets, total debt, total liabilities and leverage. For 
our sample of banks, the mean (median) of total assets is $\$ 129.74$ (27.07) billion for BHCs and \$1.45 (0.13) billion for FDIC banks, while the mean (median) of total liabilities is $\$ 117.36$ (24.12) billion for BHCs and $\$ 1.30$ (0.12) billion for FDIC banks. For BHCs, the funding cost ranges from $0.02 \%$ to $10.49 \%$ with the mean (median) of $2.05 \%(1.76 \%)$. For FDIC banks, the funding cost ranges from $0.07 \%$ to $8.48 \%$ with the mean (median) of $2.38 \%(2.19)$.

\section{[Insert Table 4 Here]}

Table 4 shows the summary statistics of time-series variables used for regression analysis. Panel A shows the results for government guarantee related variables. Panel B and Panel $\mathrm{C}$ provide summary statistics of the time series funding cost, size and leverage variables separately for large banks, small banks, and for the difference between small and large banks from 2000 to 2015 for BHCs and FDIC banks, respectively. The mean size of large BHCs is 11 times bigger than that of the small ones $(\$ 171.4$ billion versus $\$ 15.5$ billion). The mean leverage of the large banks is about $18.8 \%$, which is $4.5 \%$ higher than that of the small banks. The mean funding cost of large BHCs is $1.71 \%$ which is about $0.03 \%$ higher than that of the small BHCs. At the same time, the mean size of large FDIC banks is over 1000 time bigger than the size of the small FDIC banks ( $\$ 150.3$ billion versus $\$ 0.14$ billion). The mean funding cost of large FDIC banks $(1.68 \%)$ is on par with the mean funding cost of large BHCs, however, the funding cost of small FDIC banks is $2.1 \%$ which is $0.42 \%$ above that of the large FDIC banks. This difference in the funding costs between small BHCs and small FDIC banks can be explained by the fact that the mean size of banks in the small FDIC bank sample is over 100 times smaller than the mean size of the small BHCs. 


\section{Empirical Analysis}

In this section we report the results of our empirical analysis. First, we compute the value of the implicit government guarantee using the two- step procedure outlined in section 2. Then, we relate the value of the government guarantee to funding costs of large banks, small banks, and the funding cost spread between small and large banks while controlling for the macroeconomic conditions.

\subsection{The Value of the Implicit Government Guarantee}

Using the firms' equity and liability data at the beginning of the quarter, ${ }^{7}$ we estimate the value of the government subsidy given intervention as a put option on the firm's assets with the strike price equal to the default barrier (firm's liabilities). ${ }^{8}$ Panel A of Table 3 shows that the average value of the implicit contingent claim over a one year maturity is $\$ 23.68$ million, with the maximum of $\$ 111.2$ billion. This value represents the value of the government guarantee under the assumption that the guarantee is explicit, i.e. that the government will rescue the troubled companies with certainty. In practice, as the Lehman Brothers bankruptcy has shown, this is not the case even for large banks. One of the contributions of our study is that we define the value of the implicit government guarantee as an expected value of the government intervention and we estimate it by multiplying the value of the government subsidy given certain intervention by the probability of the government intervention. We estimate the average probability of the government intervention to be $15 \%$. We also find

\footnotetext{
${ }^{7}$ For the volatility of the equity, we use the EWMA filter to estimate from quarter to quarter, starting with the volatility estimated on the entire series for each company. We also look at an alternative definition using daily stock returns over the past 12 months. We find that the results are very similar.

${ }^{8}$ Following Levine and $\mathrm{Wu}$ (2016) and Vassalou and Xing (2004), we use one year as the time to maturity for the put option.
} 
that large firms and financial institutions are more likely to receive government support, while a large number of small firms may not be bailed out by the government. After taking into account the probability of the government intervention, we find that the average expected value of the implicit government guarantee for all firms is $\$ 12.91$ million but it can be as high as $\$ 89.2$ billion for certain companies. This can be interpreted as the average annual cost of the Too Big to Fail per company for the tax payers. According to the TARP, the total government disbursement was $\$ 623$ billion. Specifically, the top recipients were Fannie Mae (\$116 billion), Freddie Mac (\$71 billion), AIG ( $\$ 67$ billion), GM (\$50 billion), and the Bank of America ( $\$ 50$ billion). Therefore, our measure of the value of implicit government guarantee can well capture the size of the recent government bailout.

In addition, we take the quarterly mean of the estimated government guarantee variables to get the time-series data for the subsequent analysis. Panel A of Table 4 shows that the value of the contingent claim over a one year maturity ranges from about $\$ 376,000$ to $\$ 87$ million, with a $\$ 24.5$ million on average. The probability of the government bailout ranges from $4.53 \%$ to $17.73 \%$ with an average of $15.32 \%$. The mean (median) of the expected value of the implicit government guarantee for all firms over the sample period is $\$ 13.38$ (\$4.07) million. Also note that the product of the average probability with the contingent claim $(\$ 24.5 \times 0.1532=\$ 3.75$ million $)$ is much smaller than the average value of the government guarantee ( $\$ 13.38$ million). This can be explained by the fact that big companies with large values of contingent claims also have higher likelihood of the government intervention.

[Insert Figure 3 Here] 
Figure 3 plots the evolution of the value of the implicit government guarantee and LIBOR interest rate from 2000 to 2015. The value of the implicit government guarantee was quite low before the financial crisis and it dropped virtually to zero in the end of 2008, following the Lehman Brothers bankruptcy. To deal with the financial crisis the Federal Reserve pushed interest rates to their historical minimum and kept them at that level through 2015. After the financial crisis, the value of the implicit government guarantee increased significantly, reaching its peak in the middle of 2011, but it has declined in the following years. The high level of the implicit government guarantee after the financial crisis coupled with the low interest rates reflects the fact that the government continued stabilizing the economy well after the financial crisis was over. While the goal was to restore confidence in the economy and stability of the financial system, such policy came at a cost. It put a fiscal strain on the economy, reduced the GDP and delayed the economic recovery.

\section{[Insert Figure 4 Here]}

Figure 4 shows that the value of the implicit government guarantee increased drastically with the crisis for both finance and non-finance companies. Since nonfinance companies have larger average size compared to finance companies ( $\$ 2.7$ billion versus $\$ 1.6$ billion), the average value of the implicit government guarantee for nonfinance companies before the crisis was slightly larger compared to that of the finance companies ( $\$ 3.1$ million versus $\$ 2.3$ million). After the crisis the situation reversed and the finance companies enjoyed a much larger average implicit government guarantee (\$31.6 million) compared to that of the non-finance companies ( $\$ 24.4$ million). When we consider the ratio of the average value of the implicit government guarantee to the 
companies' average market value, the finance companies had larger ratios both before and after the crisis. The difference in ratios between finance and non-finance companies is more pronounced after the crisis. This is consistent with the financial sector bailout which was done in order to prevent the collapse of the entire economy.

\subsection{The Relationship between the Value of the Implicit Government Guarantee and the Funding Costs}

The spread between the funding costs of the small and large banks is often used as a proxy for the too-big-to-fail effect of the implicit government guarantee (see, for example, Baker and McArthur (2009) and Li, Qu, Zhang (2011)). The intuition behind it is that the decrease in the funding costs of large and small banks and subsequent increase in the funding costs spread can be associated with an increase in the value of the implicit government guarantee. We investigate this relationship for the costs of funds using data at BHC level from Compustat (Table 5 and Table 6) and at depositary level from FDIC (Table 7 and Table 8).

The value of the implicit government guarantee depends on the current economic conditions. To control for the state of the economy we use the GDP growth rate. Empirical evidence shows strong inverse relationship between the implicit government guarantee and the funding costs (see Table 5 and Table 7). There is a significant consistency in our results. The strong negative relationship holds for large and small companies for both BHC and FDIC funding costs measures. The inverse relationship means that a decrease in the funding costs is associated with an increase in the value of the implicit government guarantee for both large and small companies.

[Insert Table 5 Here] 
In Table 5, the one percent decrease of funding cost of large banks is associated with $\$ 744,023$ increase of the value of implicit government guarantee using the BHCs data. While this result is secondary and can be influenced by other factors, the most interesting result is the positive relationship between the spread in funding costs of small banks over large banks and the implicit government guarantee.

\section{[Insert Table 6 Here]}

Table 6 shows the one percentage increase of funding cost spread is associated with the $\$ 5.44$ million increase of the implicit government guarantee. Since the spread between the funding costs of the small and large banks is often considered as a proxy for the too-big-to-fail premium, the positive relationship confirms this intuition and reinforces our confidence in the way we estimate the value of the implicit government guarantee.

\section{[Insert Table 7 Here]}

We also observe a strong positive relationship between the banks' size and the implicit government guarantee for both small and large BHCs and FDIC banks. The positive relationship implies that larger companies enjoy higher implicit government guarantee. Finally, we explore the relationship between banks' leverage level and the implicit government guarantee for BHCs. We find strong inverse relationship for both large and small BHCs meaning that highly leveraged banks tend to have lower implicit government guarantee. After the financial crisis many companies reduced the amount of leverage which increased their implicit government guarantee.

\subsection{Crisis Effect on the Relationship between the Value of the Implicit}




\section{Government Guarantee and the Funding Costs}

In this section we explore the effect of the financial crisis on the relationship between the value of the implicit government guarantee and the funding cost spread between small and large banks. To explore this relationship we add a structural break to distinguish between before and after the crisis periods. The empirical results, for the most part, are consistent with our prior findings (see Table 6 and Table 8). For BHCs the relationship remains strong and positive both before and after the crisis. Before the crisis, the funding cost spread was increasing and so did the implicit government guarantee. After the crisis there is usually a reversal adjustment as the markets gradually return to normal. The positive after the crisis relationship implies that as the funding cost spread narrowed, the implicit government guarantee decreased. For the FDIC banks the relationship is strong and positive after the crisis but it is negative before the crisis. This result can be attributed to the FDIC insurance effect which reduces the cost of funds of the FDIC insured financial institutions. As was discussed earlier, the FDIC insurance effect should be stronger for small FDIC banks leading to a decrease in the funding cost spread between small and large banks before the crisis at the time when the implicit government guarantee was growing. The FDIC insurance effect becomes insignificant during and after the crisis which is confirmed by the positive relationship between the value of the government guarantee and the funding cost spread after the crisis.

\subsection{Robustness Check}

We perform the robustness check of our results by considering an alternative definition of the large banks. Instead of defining large banks as the top 20 banks in each 
quarter, we use Baker and McArthur (2009) definition, who define large banks as banks with more than $\$ 100$ billion in total assets and small banks as banks with less than $\$ 100$ billion in assets. For BHCs we have 7 to 16 large banks over the sample period; for FDIC banks there are 8 to 24 large banks. The samples are similar to the previous definition, but with smaller number of banks in early 2000s and more banks in recent years. This makes sense because there is an overall increase in the size of banks over the sample period. We repeat the regression analysis as specified in the previous section, but compute the funding cost variables based on the alternative definition. To save the space, the empirical results are reported in the online appendix.

The results of regressions with the alternative definition of large banks are very consistent with the results obtained with the original definition. They confirm a strong inverse relationship between funding costs and the implicit government guarantee for large and small banks for both BHCs and FDIC banks. They also confirm a strong positive relationship between the funding costs spreads of small banks over large banks and the implicit government guarantee once again supporting the TBTF effect. The introduction of the structural break to differentiate between before and after the crisis periods, has a similar effect on the signs of the coefficients as the original definition of the large banks but the resulting coefficients are less significant. Overall, the regressions with the alternative definition of the large banks strongly support and confirm our findings that there is a strong relationship between funding costs and the implicit government guarantee. 


\section{Conclusion}

The contribution of our paper is twofold. First, we provide a robust way to estimate the value of the implicit government guarantee and, second, we investigate the

link between the value of the implicit government guarantee and the funding cost spread between small and large banks.

Combining the contingent claim pricing with the likelihood of the government intervention, we estimate the value of a potential bailout enjoyed by the firms. Our estimates support the Bloomberg View's editorials, as we find that the value of the implicit government guarantee can go beyond billions of dollar for very big banks with trillions of dollars in assets and debts. Furthermore, we find that the value of the implicit government guarantee sharply increased after the 2008 financial crisis.

Since the TBTF dynamics is often approximated by the change in the spread of the funding cost of small banks relative to large banks, we assess that by constructing the time-series of funding costs of large and small banks. We find that the funding cost spread is strongly related to our estimate of the value of the implicit government guarantee. When we introduce a structural break in the relationship, we find that the relationship is much stronger and more consistent after the financial crisis. 


\section{Reference}

Araten, M. and C. Turner (2013) "Understanding the Funding Cost Differences between

Global Systemically Important Banks (G-SIBs) and non-G-SIBs in the United States", Journal of Risk Management in Financial Institutions, 6(4), 387-410.

Aymanns, C., Caceres, C., Daniel, C., and L. Schumacher, 2016 "Bank Solvency and Funding Cost", IMF Working Paper.

Baker, D. and McArthur, T., 2009, "The Value of the 'Too Big to Fail' Big Bank Subsidy," CERP Reports and Issue Briefs, 36, Center for Economic and Policy Research. Beliaeva, N., Khaksari, S., and Tsafack, G., 2015 "Implicit Government Guarantee and the CDS Spreads," Journal of Fixed Income, 25, 25-37.

Black, F., and Scholes, M., 1973, "The Pricing of Options and Corporate Liabilities," Journal of Political Economy, 81(3), 637-654.

Bloomberg View's Editorials: Why Should Taxpayers Give Big Banks $\$ 83$ Billion a Year? February $20^{\text {th }}, 2013$.

Cao, Charles, Fan Yu, and Zhaodong Zhong, 2010, “The Information Content of OptionImplied Volatility for Credit Default Swap Valuation,” Journal of Financial Markets, $13,321-343$.

Gapen, Michael, 2009. "Evaluating the Implicit Guarantee to Fannie Mae and Freddie Mac Using Contingent Claims" International Finance Review, 10, 329-352.

Greene, William, 2012 “Econometric Analysis”, 7th Edition, Prentice Hall.

Crosbie, P. and J. Bohn, 2003 “Modeling default risk”, Moody's KMV Company.

Jobst, A., and D. Gray, 2013 "Systemic Contingent Claims Analysis - Estimating Market-Implied Systemic Risk,” IMF Working Paper. 
Lambert, F., Ueda, K., Deb, P., Gray, D., and P. Grippa., 2014 "How Big is the Implicit Subsidy for Banks Considered too Important to Fail?" Global Stability Report, Chapter 3.

Levine O. and Y. Wu, 2016 "Asset Volatility and Financial Policy: Evidence from Corporate Mergers," Working Paper, University of Wisconsin-Madison.

Li, Z., Qu, S., and Zhang, J., 2011, "Quantifying the Value of Implicit Government Guarantee for Large Financial Institutions," Moody's Analytics, Quantitative Research Group.

Lucas, D, and R. McDonald., 2009 "Valuing Government Guarantees: Fannie and Freddie Revisited," Working Paper.

Merton, R., 1974 "On the pricing of Corporate Debt: The Risk Structure of Interest Rates," Journal of Finance, No. 29, pp. 449-470.

Noss, J., and R. Sowerbutts., 2012 “The Implicit Subsidy of Banks,” Financial stability paper $\mathrm{N} 15$.

O'Hara, M., and W. Shaw, 1990, "Deposit Insurance and Wealth Effects: The Value of Being 'Too Big to Fail'." Journal of Finance 45(5): 1587-1600.

Oxera. 2011“Assessing State Support to the UK Banking Sector," Oxera Consulting Ltd. Schich, S., and Y. Aydin., 2014 "Measurement and Analysis of Implicit Guarantees for Bank Debt: OECD Survey Results," OECD Journal: Financial Market Trends, issue 1. Schich, S., Bijlsma, M., and R. Mocking., 2014 "Improving the Monitoring of the Value of Implicit Guarantee for Bank Debt," OECD Journal: Financial Market Trends, issue 1. 
Schweikhard, F., and Z. Tsesmelidakis., 2012 “The Impact of Government Interventions on CDS and Equity Markets," Working Paper.

Sorkin, Andrew R., 2009, “ Too Big to Fail: The Inside Story of How Wall Street and Washington Fought to Save the Financial System ... and Themselves”, Viking Press.

Ueda, K., and di Mauro, B., 2013, "Quantifying Structural Subsidy Values for Systemically Important Financial Institutions," Journal of Banking \& Finance 37(10): $3830-3842$.

Vassalou, M., and Y. Xing, 2004, Default risk in equity returns, Journal of Finance 59, 831-868. 


\section{Appendix A. Solving for the Value of Assets, $V_{A}$, and the Volatility of Assets, $\sigma_{A}$}

The value of assets, $V_{A}$, and the volatility of assets, $\sigma_{A}$, are obtained from the following system of two equations:

$$
\left\{\begin{array}{l}
V_{E}=V_{A} \times N\left(d_{1}\right)-L \times e^{-r_{f} \tau} \times N\left(d_{2}\right) \\
V_{E}=\frac{\sigma_{A}}{\sigma_{E}} \times V_{A} \times N\left(d_{1}\right)
\end{array}\right.
$$

Combining equations (1) and (2) leads to

$$
V_{E}=V_{E} \times \frac{\sigma_{E}}{\sigma_{A}}-L \times e^{-r_{f} \tau} \times N\left(d_{2}\right)
$$

Which implies

$$
d_{2}=N^{-1}\left[\frac{V_{E}\left(\frac{\sigma_{E}}{\sigma_{A}}-1\right)}{L \times e^{-r_{f} \tau}}\right]
$$

On another hand, $d_{2}$ is given by

$$
d_{2}=d_{1}-\sigma_{A} \sqrt{\tau}=\frac{\ln \left(\frac{V_{A}}{L}\right)+\left(r_{f}+\frac{1}{2} \sigma_{A}^{2}\right) \tau}{\sigma_{A} \sqrt{\tau}}-\sigma_{A} \sqrt{\tau}
$$

Equating these two expressions [(3) and (4)] of $d_{2}$ and solving for $V_{A}$ leads to

$$
V_{A}=L \times \exp \left[\sigma_{A} \sqrt{\tau}\left(N^{-1}\left[\frac{V_{E}\left(\frac{\sigma_{E}}{\sigma_{A}}-1\right)}{L \times e^{-r_{f} \tau}}\right]+\sigma_{A} \sqrt{\tau}\right)-\left(r_{f}+\frac{1}{2} \sigma_{A}^{2}\right) \tau\right]
$$

This expression shows that the value of assets can be written as a function of the volatility of assets

$$
V_{A}=h\left(\sigma_{A}\right)
$$

On the other hand, we can use this relation in the expression of $d_{1}$ to write

$$
d_{1}=d_{1}\left(\sigma_{A}\right)
$$

And it follows from equation (2) that

$$
f\left(\sigma_{A}\right)=\sigma_{E} V_{E}-\sigma_{A} h\left(\sigma_{A}\right) N\left(d_{1}\left(\sigma_{A}\right)\right)=0
$$


Given the data on the market value of equity, $V_{E}$, the book value of debt, $L$, equity volatility, $\sigma_{E}$, and risk-free rate, $r_{f}$, we use equation (6) to solve for assets volatility, $\sigma_{A}$. Once the value of $\sigma_{A}$ is obtained, we use equation (5) to back out the value of assets, $V_{A}$. Following Levine and $\mathrm{Wu}$ (2016) and Vassalou and Xing (2004), we assume an estimation window of one year, i.e. $\tau=1$, and estimate the face value of debt as the sum of debt due within the next year and one half of the long term debt. The risk-free rate is given by the one-year Libor rate obtained from Bloomberg. $\sigma_{E}$ is estimated using the EWMA filter to estimate from quarter to quarter, starting with the volatility estimated on the entire series for each company. 
Appendix B. Variable Definitions

\begin{tabular}{|l|l|}
\hline Variable & \\
\hline$v_{g}$ & Value of the contingent claim (put option) \\
\hline$\pi_{i}$ & Probability of the government bailout \\
\hline Evg & $\begin{array}{l}\text { Value of the implicit government guarantee (expected value of the } \\
\text { put option) }\end{array}$ \\
\hline Dum_Bailout & $\begin{array}{l}\text { Dummy variable taking the value of 1 if the firm is bailed out, and } \\
\text { if not }\end{array}$ \\
\hline Dum_Finance & $\begin{array}{l}\text { Dummy variable taking the value of 1 for finance firms, and 0 for } \\
\text { non-finance firms }\end{array}$ \\
\hline Lgasset & The natural logarithm of the total assets of the firm \\
\hline FCostLarge & Funding costs for large banks \\
\hline FCostSmall & Funding costs for small banks \\
\hline FCostDiff & $\begin{array}{l}\text { Difference between funding costs of small and large banks (Small } \\
\text { Large) }\end{array}$ \\
\hline SizeLarge & Size (average asset value) of large banks \\
\hline SizeSmall & Size (average asset value) of small banks \\
\hline SizeDiff & Difference in size (average asset value: Large - Small) \\
\hline LevLarge & Average leverage for large banks \\
\hline LevSmall & $\begin{array}{l}\text { Average leverage for small banks } \\
\text { Lifference in average leverage of small and large banks (Small - }\end{array}$ \\
\hline GDP Growth & $\begin{array}{l}\text { Gummy variable taking the value of 1 after the crisis, and 0 } \\
\text { otherwise }\end{array}$ \\
\hline Growth rate of the GDP \\
\hline fiff
\end{tabular}




\section{Table 1: Summary Statistics for Bailed Out and Bankrupt Firms}

Panel A. Distribution of bankrupt and bailed out firms by industry

\begin{tabular}{cccc}
\hline & $\begin{array}{c}\text { Non- } \\
\text { Finance }\end{array}$ & Finance & Total \\
\hline Bankrupt & 1072 & 175 & 1247 \\
Row Pct & $85.97 \%$ & $14.03 \%$ & \\
Col Pct & $98.17 \%$ & $36.53 \%$ & $79.38 \%$ \\
& & & \\
Bailout & 20 & 304 & 324 \\
Row Pct & $6.17 \%$ & $93.83 \%$ & \\
Col Pct & $1.83 \%$ & $63.47 \%$ & $20.62 \%$ \\
\hline Total & 1092 & 479 & 1571 \\
& $69.51 \%$ & $30.49 \%$ & \\
\hline
\end{tabular}

Panel B. Summary statistics for variables used in the estimation of the government guarantee

\begin{tabular}{lccccc}
\multicolumn{1}{c}{ Variable } & $\mathrm{N}$ & Mean & Std. Dev. & Min & Max \\
\hline Dum_Bailout & 1571 & 0.206 & 0.405 & 0 & 1 \\
Dum_Finance & 1571 & 0.305 & 0.461 & 0 & 1 \\
Assets & 1545 & 12,066 & 103,75 & 32.5 & $2,100,385$ \\
(\$million) & 1545 & 6.79 & 1.529 & 3.481 & 14.558 \\
lgasset & & & & & \\
\hline
\end{tabular}

Panel C. Correlation coefficients

\begin{tabular}{lccc}
\hline & Bailout & $\begin{array}{l}\text { Finance } \\
\text { Industry }\end{array}$ & lgasset \\
\hline Dum_Bailout & 1 & & \\
Dum_Finance & $0.6854 * * *$ & 1 & 1 \\
lgasset & $0.36 * * *$ & $0.397 * * *$ & 1 \\
\hline
\end{tabular}

Note: Dum_Bailout is the dummy variable taking the value of 1 if the firm is bailed out, and 0 otherwise. Dum_Finance is the dummy variable taking the value of 1 for finance firms, and 0 for non-finance firms. Lgasset is the natural logarithm of the total assets of the firm. *** $\mathrm{p}<0.01, * * \mathrm{p}<0.05, * \mathrm{p}<0.1$. 


\section{Table 2: Logit Regression for the Probability of the Government Intervention}

This table shows parameter estimates of the logit regression of the probability of the government intervention. The sample includes 1571 bankrupt and bailed out companies between 2000 and 2015. Dum_finance indicates whether or not the firm belongs to the finance industry. lgasset is the natural log of the total assets.

\begin{tabular}{|c|c|c|c|c|}
\hline Variables & Model 1 & Model 2 & Model 3 & Model 4 \\
\hline Dum_Finance & $\begin{array}{c}4.534 * * * \\
{[0.245]}\end{array}$ & & $\begin{array}{c}4.676^{* * *} \\
{[0.299]}\end{array}$ & $\begin{array}{c}9.101 * * * \\
{[1.438]}\end{array}$ \\
\hline lgasset & & $\begin{array}{c}0.546 * * * \\
{[0.0449]}\end{array}$ & $\begin{array}{c}0.214 * * * \\
{[0.056]}\end{array}$ & $\begin{array}{c}0.766 * * * \\
{[0.170]}\end{array}$ \\
\hline lgasset*Dum_Finance & & & & $\begin{array}{c}-0.606 * * * \\
{[0.179]}\end{array}$ \\
\hline Constant & $\begin{array}{c}-3.982 * * * \\
{[0.226]}\end{array}$ & $\begin{array}{c}-5.307 * * * \\
{[0.335]}\end{array}$ & $\begin{array}{c}-5.814 * * * \\
{[0.471]}\end{array}$ & $\begin{array}{c}-9.833 * * * \\
{[1.370]}\end{array}$ \\
\hline AIC & 832.494 & 1342.16 & 742.288 & 733.667 \\
\hline Pseudo R2 & 0.607 & 0.173 & 0.634 & 0.640 \\
\hline Observations & 1571 & 1545 & 1545 & 1545 \\
\hline
\end{tabular}

Note: Standard errors in brackets. $* * * \mathrm{p}<0.01, * * \mathrm{p}<0.05, * \mathrm{p}<0.1$. 
Table 3: Summary Statistics of Company Level Data and Funding Cost Variables

This table provides summary statistics for listed firms, BHCs, and FDIC banks. Vg is the value of the contingent claim. $\pi_{i}$ is the probability of the government bailout. Evg is the expected value of the implicit government guarantee. Leverage is the ratio of the total debt to the total assets. Funding cost is the ratio of the total interest expenses to the average total interest bearing liabilities. Market value, total assets, total liabilities, Vg and Evg are in million. Panel A presents the descriptive statistics of firms' fundamentals and estimated government guarantee variables. Panel B presents the descriptive statistics of fundamentals and funding cost variable for BHCs. Panel $\mathrm{C}$ presents the descriptive statistics of fundamentals and funding cost variable for FDIC banks.

Panel A: Descriptive Statistics of Variables for Government Guarantee Estimated

\begin{tabular}{lcccccc}
\hline Variable & $\mathrm{N}$ & Mean & Median & Std Dev & Min & Max \\
\hline Market Value & 307,464 & 2,829 & 280 & 13,926 & 2.2 & 723,725 \\
Total asset & 307,464 & 11,347 & 554 & 94,336 & 10 & $3,879,170$ \\
Total liabilities & 307,116 & 9,279 & 286 & 87,986 & 5.3 & $3,672,760$ \\
Vg & 147,078 & 23.68 & 0 & 864.87 & 0 & 111,220 \\
$\pi_{i}$ & 307,464 & 0.15 & 0.01 & 0.25 & 0 & 0.84 \\
Evg & 147,075 & 12.91 & 0 & 667.2 & 0 & 89,200 \\
\hline
\end{tabular}

Panel B: Descriptive Statistics of BHC Level Data

\begin{tabular}{lcccccc}
\hline Variable & $\mathrm{N}$ & Mean & Median & Std Dev & Min & Max \\
\hline Total asset & 3450 & 129,744 & 27,067 & 349,629 & 28.8 & $2,577,148$ \\
Total debt & 3450 & 29,986 & 4,002 & 95,863 & 0.7 & 873,301 \\
Total liabilities & 3450 & 117,363 & 24,122 & 316,495 & 27.5 & $2,341,284$ \\
Leverage & 3450 & $17.12 \%$ & $16.67 \%$ & $8.38 \%$ & $0.26 \%$ & $51.15 \%$ \\
Funding Cost & 3450 & $2.05 \%$ & $1.76 \%$ & $1.54 \%$ & $0.02 \%$ & $10.49 \%$ \\
\hline
\end{tabular}

Panel C: Descriptive Statistics of FDIC Depository Level Data.

\begin{tabular}{lcccccc}
\hline Variable & $\mathrm{N}$ & Mean & Median & Std Dev & Min & Max \\
\hline Total asset & 523,063 & 1,446 & 129 & 26,760 & 0.1 & $2,096,114$ \\
Total liabilities & 523,063 & 1,295 & 115 & 24,183 & 0 & $1,905,556$ \\
Funding Cost & 523,063 & $2.38 \%$ & $2.19 \%$ & $1.46 \%$ & $0.07 \%$ & $8.48 \%$ \\
\hline
\end{tabular}




\section{Table 4: Summary Statistics of Time-Series Variables}

This tables provides summary statistics of time-series aggregate variables constructed for regression analysis. The number in each cell reports the average of quarterly means. Panel A presents the descriptive statistics of time-series government guarantee variables. Panel B presents the descriptive statistics of time-series variables for BHCs. Panel C presents the descriptive statistics of time-series variables for FDIC banks.

Panel A: Descriptive Statistics of Time-Series Variables for Government Guarantee Estimates

\begin{tabular}{lccccc}
\hline Variable & Mean & Median & Std Dev & Min & Max \\
\hline Vg (\$million) & 24.518 & 11.793 & 20.420 & 0.376 & 86.968 \\
$\pi_{i}$ & 0.153 & 0.155 & 0.017 & 0.045 & 0.177 \\
Evg (\$million) & 13.376 & 4.065 & 14.769 & 0.0005 & 62.984 \\
\hline
\end{tabular}

Panel B: Descriptive Statistics of Time-Series (BHC Level)

\begin{tabular}{lrrrrr}
\hline Variable & Mean & Median & Std Dev & Min & Max \\
\hline FCostLarge & $1.71 \%$ & $1.49 \%$ & $1.36 \%$ & $0.21 \%$ & $4.76 \%$ \\
FCostSmall & $1.68 \%$ & $1.50 \%$ & $1.26 \%$ & $0.21 \%$ & $4.57 \%$ \\
FCostDiff & $-0.03 \%$ & $0.01 \%$ & $0.16 \%$ & $-0.33 \%$ & $0.25 \%$ \\
SizeLarge (\$ billion) & 171.38 & 144.40 & 85.09 & 84.07 & 376.14 \\
SizeSmall (\$ billion) & 15.46 & 13.95 & 4.95 & 9.49 & 26.96 \\
SizeDiff (\$ billion) & 155.92 & 130.03 & 80.59 & 73.88 & 349.18 \\
LevLarge & $18.78 \%$ & $20.65 \%$ & $4.99 \%$ & $10.31 \%$ & $26.20 \%$ \\
LevSmall & $14.33 \%$ & $16.39 \%$ & $3.64 \%$ & $7.76 \%$ & $19.05 \%$ \\
LevDiff & $-4.45 \%$ & $-4.10 \%$ & $2.21 \%$ & $-9.27 \%$ & $0.30 \%$ \\
GDP Growth & $1.81 \%$ & $2.20 \%$ & $2.46 \%$ & $-8.20 \%$ & $6.90 \%$ \\
\hline
\end{tabular}

Panel C: Descriptive Statistics of Time-Series Variables (FDIC Level)

\begin{tabular}{lrrrrr}
\hline Variable & Mean & Median & Std Dev & Min & Max \\
\hline FCostLarge & $1.68 \%$ & $1.36 \%$ & $1.36 \%$ & $0.19 \%$ & $4.61 \%$ \\
FCostSmall & $2.10 \%$ & $2.04 \%$ & $1.26 \%$ & $0.49 \%$ & $4.95 \%$ \\
FCostDiff & $0.42 \%$ & $0.46 \%$ & $0.37 \%$ & $-0.47 \%$ & $1.11 \%$ \\
SizeLarge (\$ billion) & 150.26 & 151.15 & 39.92 & 90.46 & 223.01 \\
SizeSmall (\$ billion) & 0.14 & 0.14 & 0.03 & 0.09 & 0.19 \\
SizeDiff (\$ billion) & 150.12 & 151.02 & 39.89 & 90.37 & 222.82 \\
\hline
\end{tabular}




\section{Table 5: Implicit Government Guarantee and BHC Funding Cost}

For funding cost, size and leverage, models below show the relationship between their averages and the average value of the government guarantee, which represent the expected value of the put option enjoyed by a firm under the implicit government guarantee. Independent factors are built here using data at the BHC Level from Compustat. All variables are quarterly form 2000 Q1 to 2015 Q4. Robust $t$ statistics in brackets * significant at 10\%; ** significant at 5\%; *** significant at $1 \%$.

\begin{tabular}{|c|c|c|c|c|c|c|}
\hline & Model 1 & Model 2 & Model 3 & Model 4 & Model 5 & Model 6 \\
\hline FCostLarge & $\begin{array}{c}-744.023^{* * *} \\
{[8.08]}\end{array}$ & & & & & \\
\hline FCostSmall & & $\begin{array}{c}-783.273^{* * *} \\
{[7.93]}\end{array}$ & & & & \\
\hline SizeLarge & & & $\begin{array}{c}0.053 * * * \\
{[3.77]}\end{array}$ & & & \\
\hline SizeSmall & & & & $\begin{array}{c}1.4048 * * * \\
{[6.34]}\end{array}$ & & \\
\hline LevLarge & & & & & $\begin{array}{c}-238.083^{* * *} \\
{[10.70]}\end{array}$ & \\
\hline LevSmall & & & & & & $\begin{array}{c}-333.166 * * * \\
{[10.44]}\end{array}$ \\
\hline GDP & & & & & & \\
\hline Growth & $\begin{array}{l}-6.096 \\
{[0.12]}\end{array}$ & $\begin{array}{c}-10.955 \\
{[0.22]}\end{array}$ & $\begin{array}{c}62.9131 \\
{[1.19]}\end{array}$ & $\begin{array}{c}46.834 \\
{[1.00]}\end{array}$ & $\begin{array}{c}54.223 * \\
{[1.79]}\end{array}$ & $\begin{array}{l}8.660 \\
{[0.30]}\end{array}$ \\
\hline Constant & $\begin{array}{c}26.239 * * * \\
{[9.50]}\end{array}$ & $\begin{array}{c}26.753 * * * \\
{[9.43]}\end{array}$ & $\begin{array}{c}3.2488 \\
{[0.92]}\end{array}$ & $\begin{array}{c}-9.187 * * \\
{[2.42]}\end{array}$ & $\begin{array}{c}57.098 * * * \\
{[11.38]}\end{array}$ & $\begin{array}{c}60.959 * * * \\
{[11.24]}\end{array}$ \\
\hline R-squared & 0.464 & 0.439 & 0.106 & 0.234 & 0.660 & 0.679 \\
\hline
\end{tabular}


Table 6: Implicit Government Guarantee and BHC Funding Cost Difference

For funding cost, size and leverage, models below show the relationship between their averages and the average value of the government guarantee, which represent the expected value of the put option enjoyed by a firm under the implicit government guarantee. Independent factors are built here using data at the BHC Level from Compustat. A parameter for a variable with suffix "ACt" represents the change after the crisis. All variables are quarterly form 2000 Q1 to 2015 Q4. Robust $t$ statistics in brackets * significant at 10\%; ** significant at 5\%; *** significant at $1 \%$.

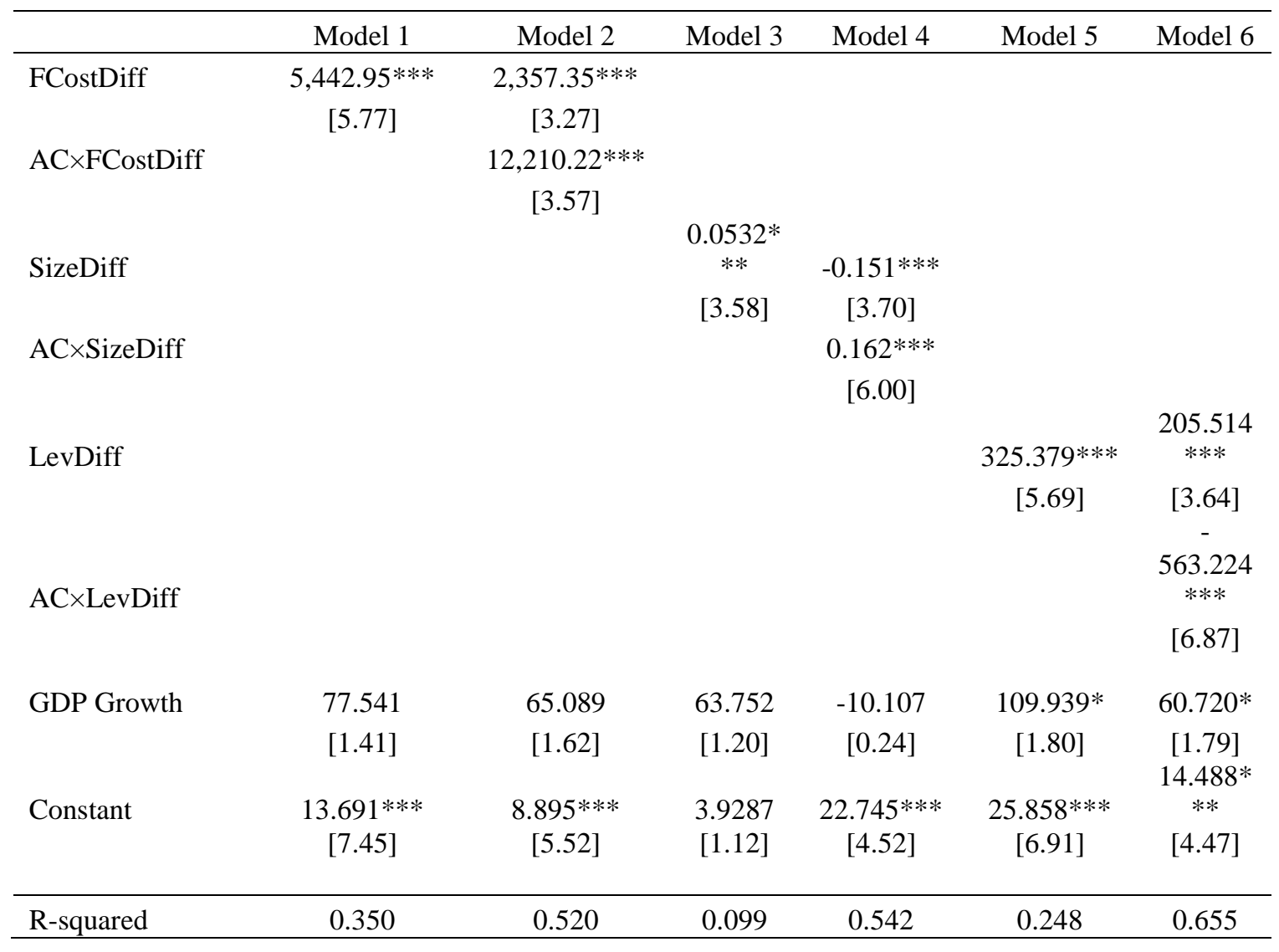




\section{Table 7: Implicit Government Guarantee and FDIC Funding Cost}

For funding cost, size and leverage, models below show the relationship between their averages and the average value of the government guarantee, which represent the expected value of the put option enjoyed by a firm under the implicit government guarantee. Independent factors are built here using data at the depository Level from FDIC. All variables are quarterly form 2000 Q1 to 2015 Q4. Robust t statistics in brackets * significant at 10\%; ** significant at 5\%; *** significant at $1 \%$.

\begin{tabular}{|c|c|c|c|c|}
\hline & Model 1 & Model 2 & Model 3 & Model 4 \\
\hline FCostLarge & $\begin{array}{c}-732.756 * * * \\
{[8.38]}\end{array}$ & & & \\
\hline FCostSmall & & $\begin{array}{c}-797.329 * * * \\
{[8.20]}\end{array}$ & & \\
\hline SizeLarge & & & $\begin{array}{c}0.253 * * * \\
{[8.32]}\end{array}$ & $337.479 * * *$ \\
\hline SizeSmall & & & & [8.59] \\
\hline GDP & & & & \\
\hline Growth & $\begin{array}{l}-4.879 \\
{[0.10]}\end{array}$ & $\begin{array}{c}-24.868 \\
{[0.51]}\end{array}$ & $\begin{array}{c}102.103 * * * \\
{[2.73]}\end{array}$ & $\begin{array}{c}98.051 * * \\
{[2.38]}\end{array}$ \\
\hline Constant & $\begin{array}{c}25.8 * * * \\
{[9.45]}\end{array}$ & $\begin{array}{c}30.590 * * * \\
{[9.76]}\end{array}$ & $\begin{array}{c}-26.535 * * * \\
{[6.81]}\end{array}$ & $\begin{array}{c}-34.901 * * * \\
{[7.18]}\end{array}$ \\
\hline R-squared & 0.457 & 0.449 & 0.481 & 0.464 \\
\hline
\end{tabular}


Table 8: Implicit Government Guarantee and FDIC Funding Cost Difference

For funding cost, size and leverage, models below show the relationship between their averages and the average value of the government guarantee, which represent the expected value of the put option enjoyed by a firm under the implicit government guarantee. Independent factors are built here using data at the depository Level from FDIC. A parameter for a variable with suffix "AC" represents the change after the crisis. All variables are quarterly form 2000 Q1 to 2015 Q4. Robust $t$ statistics in brackets * significant at 10\%; ** significant at 5\%; *** significant at $1 \%$

\begin{tabular}{lcccc}
\hline & Model 1 & Model 2 & Model 3 & Model 4 \\
\hline FCostDiff & $939.128^{* *}$ & $-547.642^{* *}$ & & \\
AC & {$[2.20]$} & {$[2.09]$} & & \\
SizeDiff & & $3,536.689 * * *$ & & \\
& & {$[4.68]$} & & \\
AC $\times$ SizeDiff & & $0.254^{* * *}$ & -0.061 \\
& & {$[8.32]$} & {$[1.29]$} \\
GDP Growth & & & $0.149 * * *$ \\
& & & & {$[6.15]$} \\
Constant & {$[1.46]$} & {$[0.14]$} & {$[2.73]$} & -5.235 \\
& $7.848^{* * *}$ & $7.514 * * *$ & $-26.527 * * *$ & $10.19]$ \\
& {$[3.80]$} & {$[3.85]$} & {$[6.81]$} & {$[1.73]$} \\
\hline R-squared & & & & \\
\hline
\end{tabular}


Figure 1. Funding Cost Difference: Bank Holding Companies verses FDIC banks
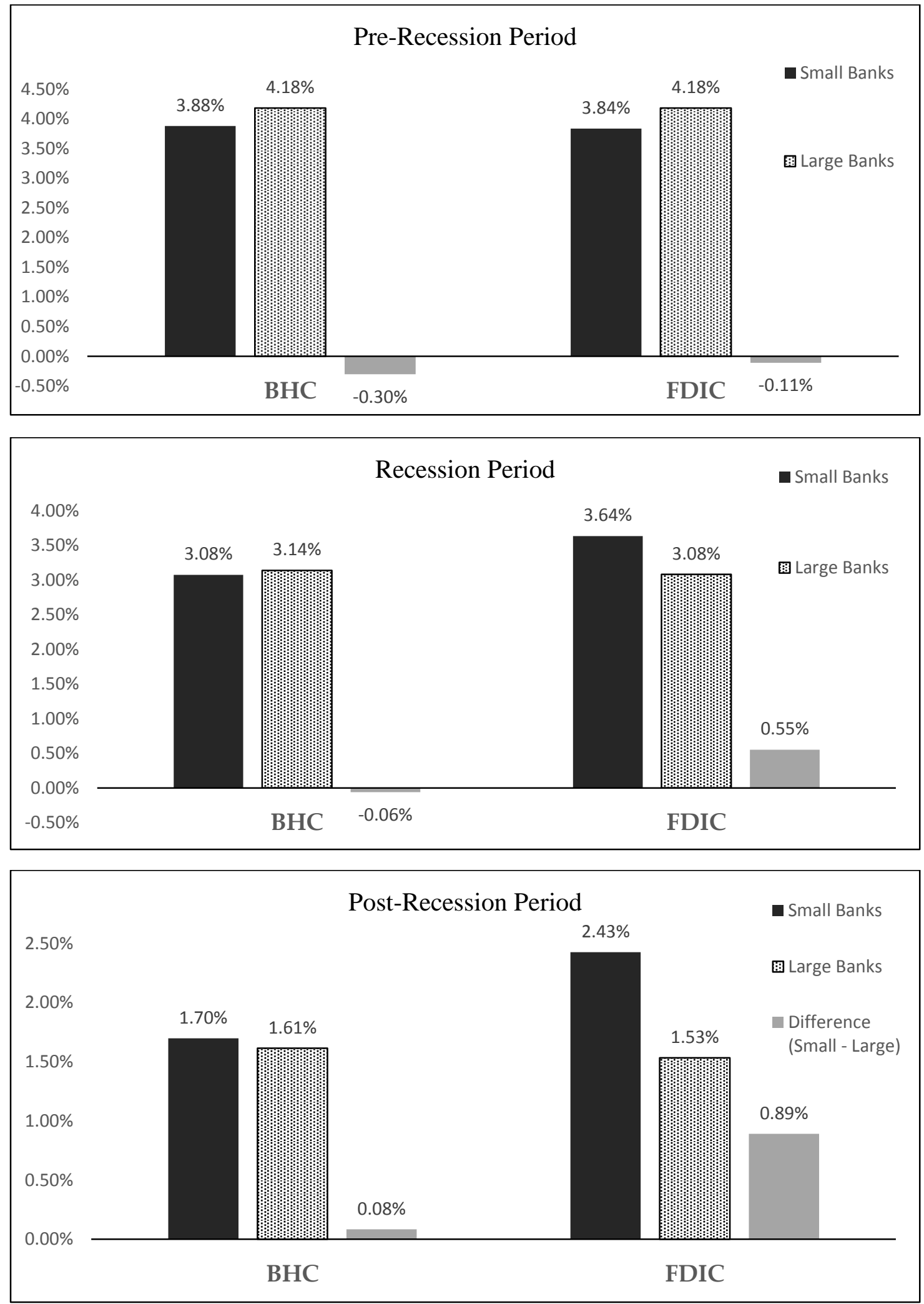
Figure 2.1. Dynamics of the Funding Costs for BHC banks

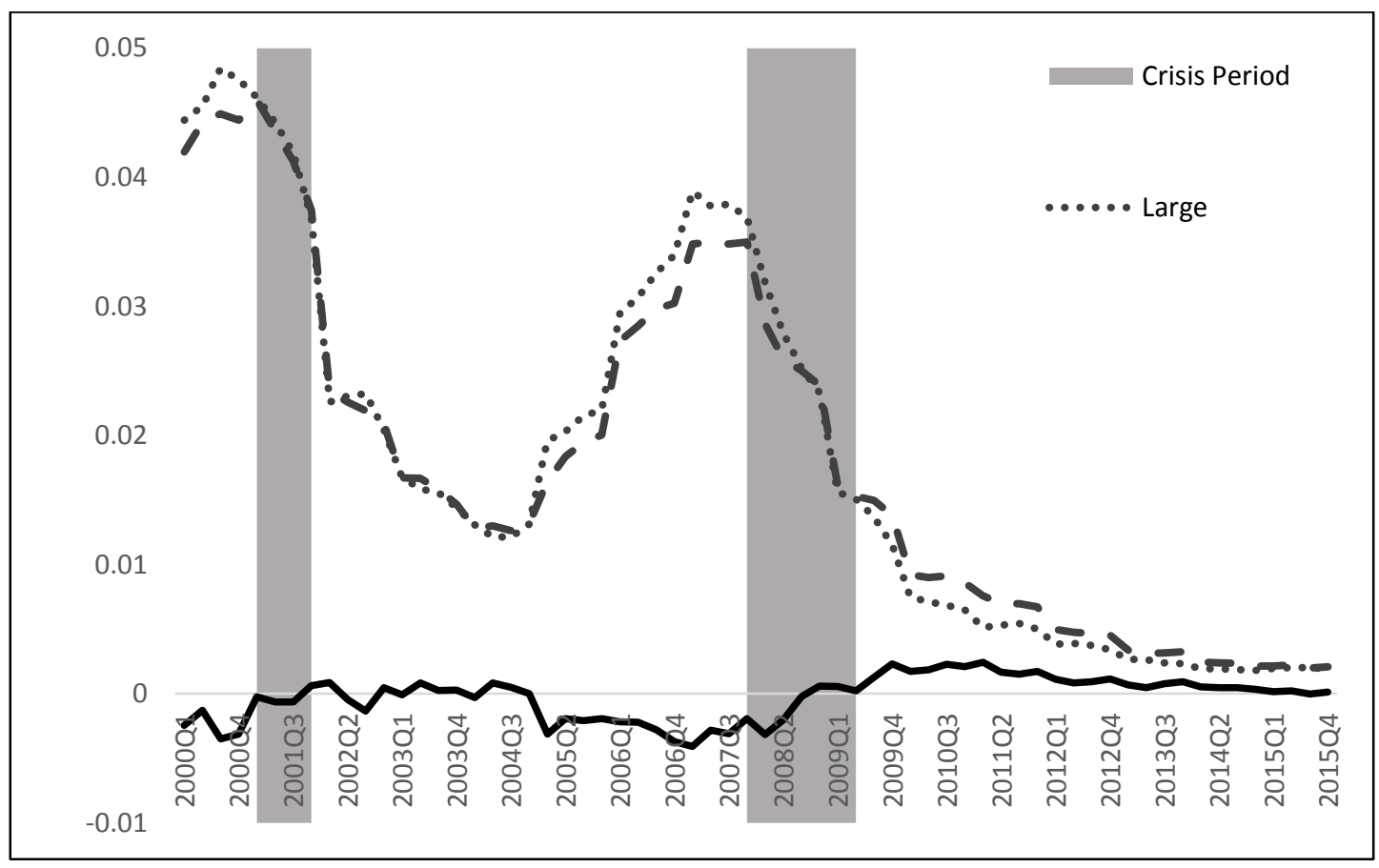

Figure 2.2 Dynamics of the Funding Costs for FDIC banks

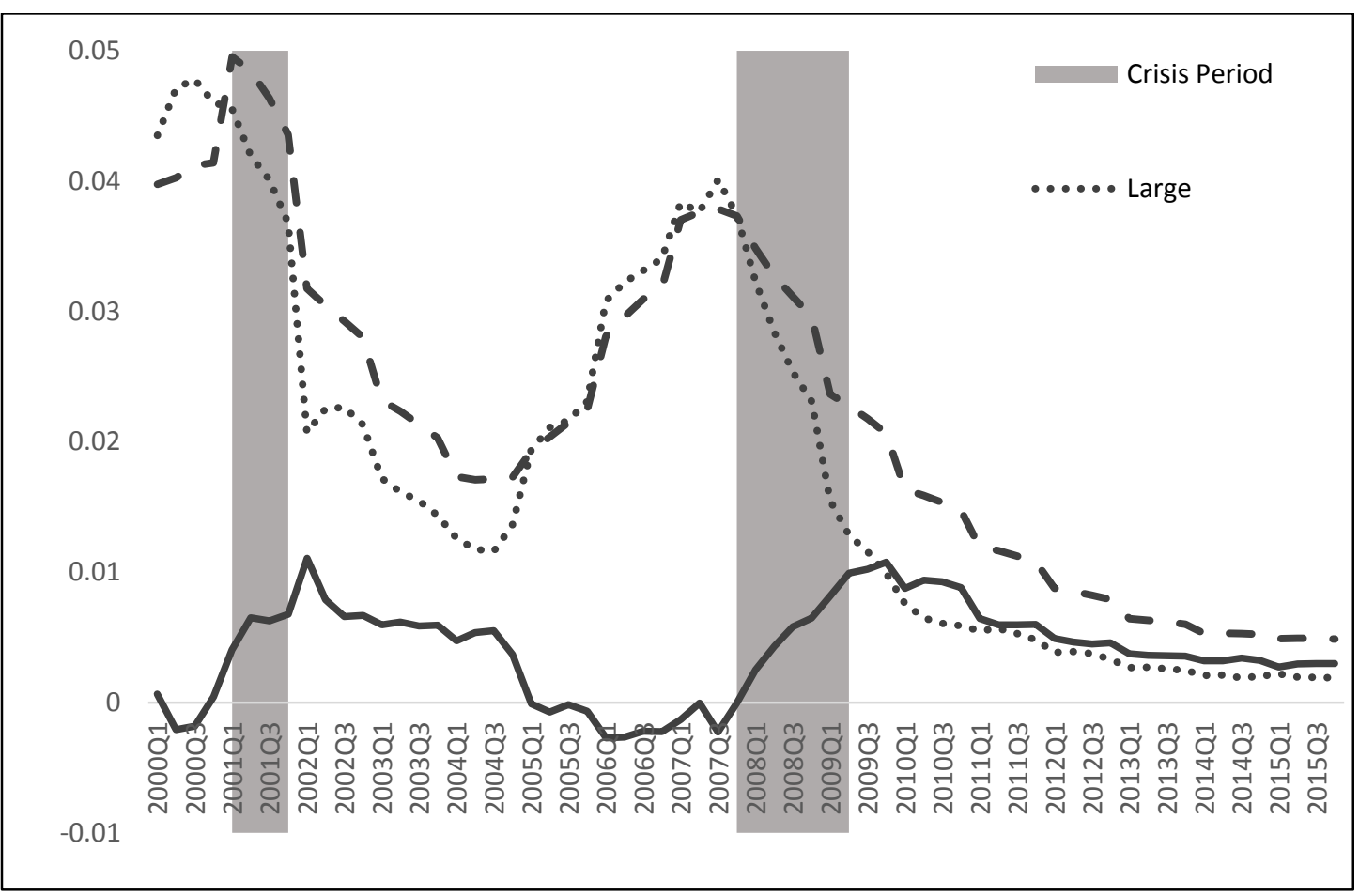


Figure 3. Evolution of the Value of the Implicit Government Guarantee

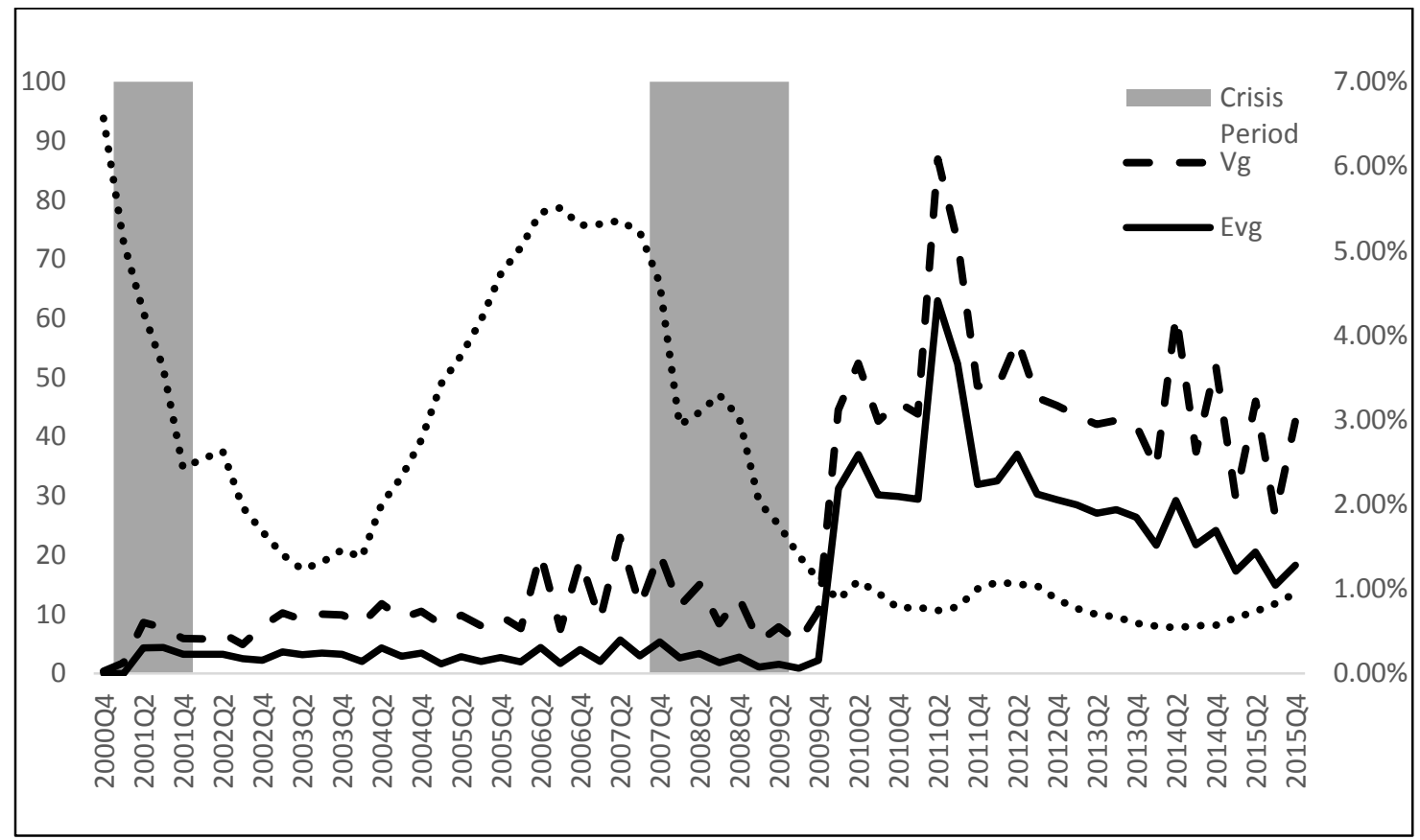


Figure 4. The Crisis Effect on the Value of Implicit Government Guarantee

Average value of implicit government guarantee for finance and non-finance companies before and after the crisis (in \$million)

- Finance Non Finance

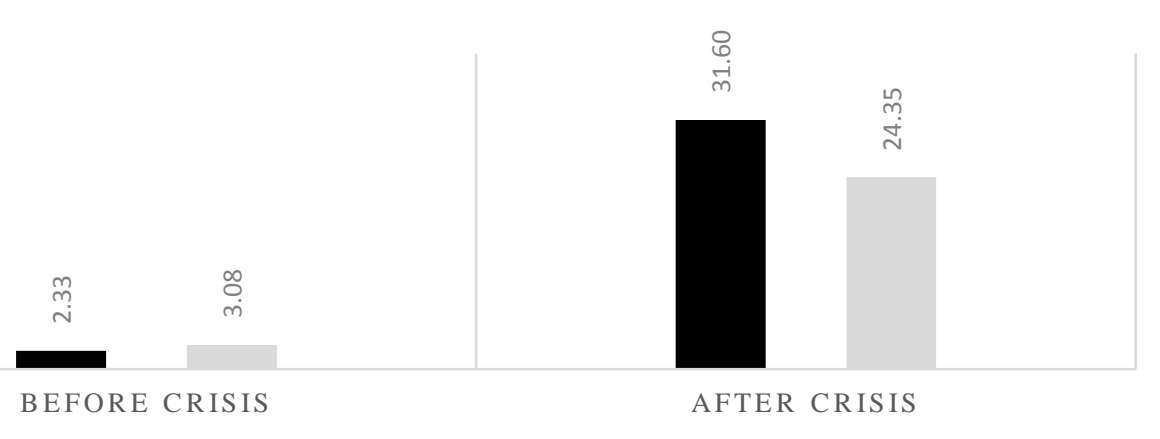

Average Market value for finance and non-finance companies before and after the crisis (in \$million)

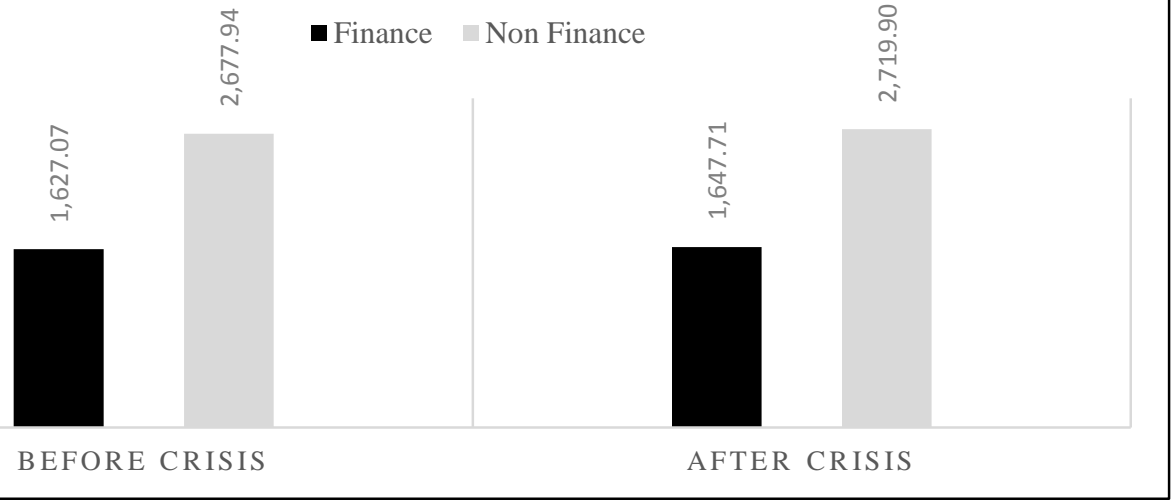

Ratio of average value of implicit government guarantee over the Market value for finance and non-finance companies before and after the crisis

- Finance Non Finance

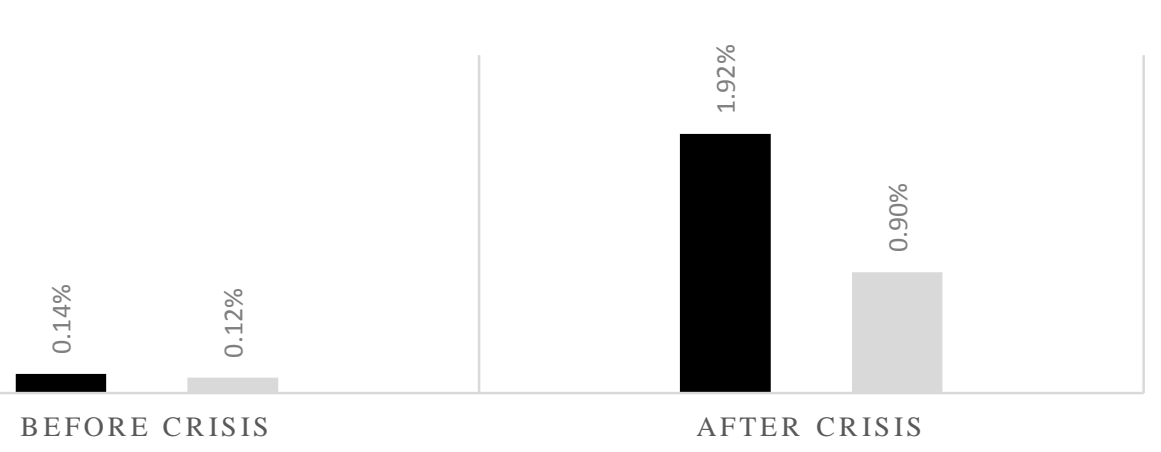




\title{
Manuscript 3
}

Prepared for submission to Journal of Corporate Finance.

\section{Implicit Government Guarantees and Agency Problems}

\begin{abstract}
The corporate bond sector has grown tremendously over the past decade. Rapid growth in Chinese corporate indebtedness and corporates' ability to pay back their liabilities have become a persistent concern for regulators and investors in recent years. In this paper, we examine the determinants of the pricing of Chinese corporate bonds and potential agency costs arising from implicit government guarantees (IGG) for state owned enterprises (SOEs). We show that the yield of central government SOE bonds is 85 bps lower than that of non-SOE bonds after controlling for firm-specific, bondspecific characteristics, and macroeconomic variables. Further, quantifying IGG with (the lack of) bond yield sensitivity to equity volatility, we present evidence on the dark side of IGG - high IGG firms are subject to greater agency costs; they are more likely to over-invest to negative NPV project, suffering poor operating performance.
\end{abstract}




\section{Implicit Government Guarantees and Agency Problems}

\section{Introduction}

The rapid growth in Chinese corporate indebtedness and corporates' ability to pay back their liabilities have become a persistent concern for regulators and investors in recent years. The annual issuance of corporate debt in the amount of 4.3 trillion CNY as of the end of 2017, from 8.5 billion CNY in $2000^{1}$. Of this total, about $28.6 \%$ are central government bonds, $53.5 \%$ are local government bonds, and the rest are non-state owned enterprise bonds. It is well known that government tends to bail out state owned enterprises (SOEs) when they are in trouble. In this paper, we examine the determinants of the pricing of Chinese non-financial corporate bonds, which are publicly traded in the interbank bond market as well as the exchange markets, and potential agency costs of implicit government guarantees.

A salient feature of the Chinese financial system is the active involvement of the China's government in the economy (Brunnermeier, Sockin, and Xiong, 2017). Stateowned enterprises in China are established and backed by the central and local government. Unlike private owned companies, SOEs shoulder more political and social responsibilities than non-SOEs, such as creating jobs, supporting strategic industries, and maintaining stability. As a result, central and local governments typically subsidize SOEs, explicitly or implicitly. Investors considered bonds issued by stated owned enterprises in China's domestic markets to have implicit guarantees

\footnotetext{
${ }^{1}$ There are five types of corporate indebtedness: enterprise bonds, corporate bonds, medium term note (MTN), commercial paper, and private placement note (PPN). In 2017, the annual issuance amount of enterprise bonds is 373 billion CNY; that of corporate bonds is 1,102 billion CNY; that of MTN is 1,037 billion CNY, that of commercial paper is 2,378 billion CNY; and that of PPN is 495 billion CNY.
} 
by the government and are rarely default because the government would bail out systemically important enterprises when they are in financial distress. Bonds of SOEs are more like risk-free government bonds, instead of risky corporate bonds. Naturally, this feature has impacts on capital allocations across different assets. Industries populated with SOEs can easily attract capital with a lower financial cost than those mainly occupied non-SOEs. The government support has provided competing advantages for SOEs over non-SOEs though easy access to capitals, lower financial cost.

On the other hand, state-owned enterprises are potentially negatively affected by government implicit guarantees. Specifically, implicit guarantees may directly influence the efficiency of SOEs through the potential agency cost on corporate managers. For example, most corporate managers are appointed by government officials. The ill-functional compensation plan provides little incentives for management to maximize shareholder's interest. The high agency cost may weaken the disciplinary effect of debt and discourage managers from exerting efforts on project. The heavy policy burden, the manager's incompetence, the collusion between two state agencies (local official and SOE manager) and the inflexible compensation schedule have caused an abnormally high agency costs, the low productivity and poor performance of a SOE. In addition, debtholders are less concerned with the defaults risk because of the implicit government guarantees on the debt of SOEs. This leads to monitor corporate investments.

We first investigate whether there is an implicit government guarantee from governments. We find that, on average, yield of non-SOE bonds is about 85 bps higher 
than that of the central government SOE (CG-SOE) bonds after controlling for firmspecific, firm-specific characteristics, and macroeconomic variables. In addition, the yield of local government SOE (LG-SOE) bonds is about 18 bps higher than that of CG-SOE bonds. Our findings suggest that SOEs receive implicit government guarantees from both the central and local governments. Our results remain robust with a subsample of corporate bonds, enterprise bonds and medium term notes (MTN) and investment grade bonds and a subsample of investment grade bonds.

Further, we extend the Merton (1974)'s theoretic framework to motivate the role of implicit government guarantees on bond pricing. In essence, the Merton framework predicts a positive relation between corporate bond yields and equity volatility. Nevertheless, the existence of IGG reduces the connection between bond yields and equity volatility. We, accordingly, measure IGG using bond yield sensitivity to equity volatility. In the subsequent empirical analysis, we demonstrate that the yield spread sensitivity to equity volatility measure can largely capture the benefit of implicit government guarantees. Defining the IGG as the negative equity volatility betas, we show that IGG is positively related to SOE dummy and negatively non-SOE dummy.

Next we examine the effect of government guarantees on firm operating performance. This analysis is motivated by the fact that the presence of implicit government guarantees may foster the agency conflicts between shareholders and bondholders. We find an inverse relation between the magnitude of implicit guarantee of a firm and its operating performance, i.e. the operating performance is relatively lower for SOEs while higher for non-SOEs. We further study the implicit government guarantee effect on stock performance. Interesting, although the difference in 
operating performance, we find that there is no significant difference in stock performance between SOEs and non-SOEs, suggesting that the implicit government guarantees are perceived by investors. After controlling for bond and firm characteristics, IGG is associated with positive stock performance.

The paper contributes to the literature on implicit government guarantee in several perspectives. First, we find that SOEs enjoy lower debt financing cost than non-SOEs because of the implicit government guarantees from the central and local governments. Second, we propose a simple model and use yield spread sensitivity to equity volatility to quantify the implicit government guarantees. Third, we are among the first to look at the agency cost of implicit government guarantees from the perspective of corporate debt.

The remainder of the paper is organized as follows. Section 2 describes the background of Chinese non-government bond market and reviews the related literature of implicit government guarantees. Section 3 provides empirical framework and hypothesis. Section 4 introduces the data and summary statistics. Section 5 presents our empirical results, and section 6 concludes.

\section{Background and Literature Review}

\subsection{Overview of the Chinese non-government bond market}

The Chinese bond market is dominated by government and government-related issues. According to Wind 2016 annual report, the size of the government and government related bonds is about $\$ 25$ trillion at the end of 2016 . While the market share of the corporate bonds is small, it has increased significantly over the last two decades. 
In 1984, state owned-enterprises (SOEs) were allowed to issue corporate bonds subject to the approval of the central bank. In the early 1990s, local government obtained permission to enable local government-owned enterprises to issue bond and raised considerable amount of capital through the bond markets. Many of the issuers default and cause financial instability. To strengthen the regulation, the government armed the administrative rules and took steps to separate securities and banking industry, which led the size of the market fall back to the 1980 level. Consequently, all corporate bonds issued had AAA rating since $100 \%$ bank guarantee was required for issuance. In addition, the coupon rates were set by the government. The market grew slowly in 1990s with only a limited number of stated owned enterprises being allowed in the market.

China's corporate bond markets have experienced an unprecedented boom since the mid-2000s. In 2006, the first corporate bond without a third-party guarantee was issued, initiating the development of the real corporate credit market in China. The corporate bond market has increased significantly over the last decade. The annual number of issues grew more than 25 times and annual amount of issuance increased by almost 100 times from 2006 to 2016 .

\subsection{Implicit guarantee by Chinese government}

It is well known that government tends to bail out big and systematically important firms when they are in trouble. During the 2008-2009 financial crisis, US government released the Troubled Asset Relief Program (TARP) and bailed out a large number of financial institutions. For example, the total bailout amount of AIG is up to $\$ 182$ billion. Moreover, real-sector firms that have been bailed out by their home 
governments include Groupe Bull SA (France), Norilsk Nickel (Russia), Bangkok Land (Thailand), Malaysian Airline System (Malaysia), and Railtrack UK). Existing studies (e.g., O'Hara and Shaw, 1990, Ueda and di Mauro, 2013) show that such implicit guarantees have real implications for firms' credit ratings and financing costs.

State-owned enterprises (SOEs) in China shoulder more political responsibilities than non-SOEs, such as creating jobs, supporting strategic industries, and maintaining stability. Central and local governments typically subsidize SOEs, explicitly or implicitly. Investors considered bonds issued by stated owned enterprises in China's domestic markets to have implicit guarantees by the government and were optimistic that the government would bail out systemically important enterprises when they are in financial distress.

However, in 2015, Baoding Tianwei Co., a state owned enterprises owned by the central government of China, announced its default on its interest payments. This became the first central government backed company to default on a domestic bond. Since Tianwei's default in 2015, several large SOEs have defaulted or restructured debt. $^{2}$ The serial defaults of SOEs indicate that the absence of government guarantees of Tianwei is not an isolated event, and the fact that the Chinese government would never let state owned borrowers default has officially become history.

\footnotetext{
${ }^{2}$ In October 2015, Sinosteel Co., a state-owned steelmaker, failed to pay interest due on 2 billion CNY notes maturing in 2017. On March 28, 2016, Dongbei Special Steel Group, owned by the government of Liaoning province, failed to make an 852 million CNY bond payment and filed for bankruptcy on October 10, 2016. In April 2016, Shanxi Huayu, which is $49 \%$ owned by state-owned China National Coal Group Corp., failed to pay 637.7 million CNY in principal and interest on its domestic short-term commercial paper. In April 2016, China Railway Materials Co., China's largest supplier of iron-rail track and other railroad building materials, suspended trading of 16.8 billion CNY worth of outstanding bonds and was pursuing potential debt restructuring plans with creditors.
} 


\subsection{Agency Cost and SOEs}

On the other hand, implicit guarantees may directly influence the profitability and efficiency of firms through their effect on the expectations of managers. The potential agency costs may discourage corporate managers from exerting efforts to maximize firm's value and shareholder's interest. Studies find that state ownership has a negative impact on the profitability and efficiency of firms (Megginson and Netter (2001)). Many different governments have sold their SOEs to private investors in hopes that the generally unsatisfactory operating performance of these firms can be improved by the discipline of private ownership. Alternatively, China has implemented major economic reforms with minimal privatization through the conversion of SOE governance into a modern corporate governance structure. Aviazian, Ge and Qiu (2005) find that corporatization has had a significantly positive impact on SOE performance. Moreover, the recent Split-Share Structure Reform, which converts all non-tradable share into legitimate tradable shares, has boosted SOE output, profits and employment (Liao, Liu and Wang, 2014).

According to Zhou and Wang (2000), more than 90\% SOE managers are directly appointed by their superior government official. The politician can manipulate the SOEs' behavior through the managers that they appointed. The incentives of SOE managers is to pursue political goods rather than to maximize firm's value. Moreover, local governments are heavily involved in most of the investment decisions of SOEs. The heavy policy burden, the manager's incompetence, and the collusion between two state agencies (local official and SOE manage) cause the low productivity and poor performance of a SOE. 
In addition, the ill-functioning managerial incentive scheme have caused an abnormally high agency costs. SOEs offer low salaries and inflexible compensation to managers. The line between government official and SOE manager is ambiguous, and there are specified salaries for different ranks of government officials. It often happens that a SOE manager is paid according to her rank as government official instead of on her real managerial effort.

\section{Empirical Framework and Hypotheses}

\subsection{Empirical Framework for Implicit Guarantee}

We approach the value of implicit guarantee from the perspective of equity volatility. We assume that the value of firm assets (v) follows Geometric Brownian motion. A firm issues debt and the face value of the debt is D. Assume that the bond only defaults at maturity. The value of the firm's debt (d) has the following payoff:

$$
\begin{array}{ll}
\mathrm{d}=\mathrm{D} & (\mathrm{v}>\mathrm{D}) \\
\mathrm{d}=\mathrm{v} & (\mathrm{v}<\mathrm{D})
\end{array}
$$

We further rewrite the above equation as the following:

$$
\mathrm{d}=\mathrm{D}-\mathrm{p}
$$

where $\mathrm{p}$ has the following payoff:

$$
\begin{array}{ll}
\mathrm{p}=0 & (\mathrm{v}>\mathrm{D}) \\
\mathrm{p}=\mathrm{D}-\mathrm{v} & (\mathrm{v}<\mathrm{D})
\end{array}
$$

It should be noted that $\mathrm{p}$ is a put option with its exercise price at $\mathrm{D}$. We name it as the default option. In words, debt may be considered as a risk free debt, D, minus value of the default put option. This is consistent with Merton (1974) that the holders of risky 
corporate bonds can be thought of as owners of riskless bonds who have issued put option to the holders of the firm's equity.

A phenomenon is that Chinese firms, particularly state owned enterprises (SOEs), rarely default their bonds. The first SOE default in 2015 indicates that the government will not fully back the debt of state-owned enterprises. Similarly, few defaults occur in the municipal bond market, and studies attribute the low default of municipal bonds as evidence to potential existence of an implicit government guarantee (IGG). We model IGG (in a particular form) below. If the firm asset value falls below $\mathrm{D}$, but above $\mathrm{K}$ $(<D)$, the government will bail out the firm. In other words, the government will not bail out a firm when its asset value is too low (below $\mathrm{K}$, which is the lower bound for a firm to receive implicit guarantee from the government). As a result, we have the following expression for the value of the debt:

$$
\begin{array}{ll}
\mathrm{d}=\mathrm{D} & (\mathrm{v}>\mathrm{K}) \\
\mathrm{d}=\mathrm{v} & (\mathrm{v}<\mathrm{K})
\end{array}
$$

Accordingly, the value of the guarantee is:

$$
\begin{array}{ll}
\mathrm{g}=\mathrm{D}-\mathrm{v} & (\mathrm{D}>\mathrm{v}>\mathrm{K}) \\
\mathrm{g}=0 & (\mathrm{v}<\mathrm{K})
\end{array}
$$

Jointly considering (4) and (5), the presence of guarantee lowers the firm's default probability. We may consider the combination of the default put and the implicit guarantee as a straddle -- to short a put option at the exercise price of D (same as the default put) and in the meantime long a put option at the exercise K. The default put option value is reduced by the amount of IGG. We may consider $g$ as a (different) put option that firm obtains from government (a free insurance). With IGG, value of 
the put option is $\mathrm{p}-\mathrm{g}$. Consequently, bond value increases by $\mathrm{g}$, resulting in a lower yield relative to a similar firm without IGG.

\subsection{Hypotheses}

The above framework following Merton (1974) has a clear implication -- based on $\mathrm{Eq}(2)$, when volatility increases, the value of put option increases, benefiting equityholders at the expenses of bondholders. Bond yields would be highly correlated with equity volatility (precisely, it should be asset volatility). Implicit government guarantees benefit bondholders, increasing bond value and lowering yields of bonds. This will make bond yields less connected with equity volatility.

Hypothesis 1: Higher IGG indicates lower sensitivity to equity volatility.

A side benefit is that the relationship between bond yields and equity volatility offers us a potential measure of a firm's IGG. Following this idea, we quantify IGG of a firm using the lack of sensitivity in bond yields and equity volatility. This allows us to explore the dark side of an IGG.

Having an IGG is not without costs. With an IGG, debtholders are less concerned with corporate defaults risk because of the implicit government guarantees on the debt of SOEs. In the model setting, when an IGG lowers the value of the default put, bondholders have a lower incentive to closely monitor equityholders.

Noted in the literature, the conflict between debtholders and equityholders results in either underinvestment or overinvestment problems. In a financial system that debtholders are protected by the government when firms are in financial distress, the underinvestment problem would be less problematic. Rather, overinvestment is a 
severe issue plaguing corporates. As discussed in the introduction, most corporate senior managers are appointed by government officials. Their promotions typically are not performance driven; rather they are tied to the size of the company. Consequently, over-investment and empire building are expected to be prevalent in high IGG firms. This reasoning results in the second hypothesis.

Hypothesis 2: Agency cost is positively related to the implicit government guarantees. Thus, agency cost indicates lower yield spread volatility.

\section{Data}

Data on Chinese bond issuance, transaction and characteristics are provided by the WIND Information Co. Ltd. We obtain the bond issuance data, such as offering date, offering price, offering amount, coupon rate, coupon type, issue type, issuer type, credit ratings etc. For each bond transaction at day t, we observe its close price, trading volume and yield to maturity. Yield spread is then defined as the difference between the bond yield and the associated yield of the treasury yield curve at the same maturity. The accounting data is obtained from China Stock Market \& Accounting Research (CSMAR). We use a sample period from 2006 to 2016.

There are total of 29,740 bond issues from the sample period. We apply several data filters and exclude the following bond issues. 1) Bonds issues where the type of issuers (SOEs or non-SOEs) cannot be identified. 2) Offering dates, offering price and bond yields are missing.

Table 1 reports the annual number of issuers and aggregate amount of issuance of all bonds and various bond issuers. We divide our sample into three subcategories by 
issuer type: Central SOE, Local SOE and Non-SOE. Central SOE is a state owned enterprise (SOE) by Chinese central government; Local SOE is a state owned enterprise (SOE) by Chinese local government; and Non-SOE is an issuer not owned by the government. The number of bond issues has increased significantly over the last two decades. The annual number of issues grows from 297 in 2006 to 7878 in 2016. The annual amount issued increases from 353 million CNY to 14 Trillion CNY.

Table 2 reports the number of bond issues and bond yields of various bond issue types. According to WIND, bonds are classified by enterprise bonds (5,313 issues), corporate bonds (4,926 issues), medium term notes (4,427 issues), private placement notes (3,874 issues), commercial paper (10,519 issues) and financial bonds (492 issues) $)^{3}$. The average bond yields of each subcategory are 5.94\%, 5.22\%, 4.87\%, $6.00 \%, 4.12 \%$, and $4.35 \%$, respectively. We further divide each bond issue category into three bond issuers. Non-SOEs tend to have higher bond yield than that of central SOEs and local SOEs. The average bond yields of non-SOEs are higher than the average for each issue types.

Table 3 reports the number of bond issues and bond yield of various rating groups. The sample is classified into various rating groups, AAA (6,205 issues), AA+ (5,528 issues), AA (8,642 issues), AA- (657 issues), A (6,919 issues), BBB or lower (15 issues) and not rated (1,422 issues). The vast majority of Chinese bonds are rated

\footnotetext{
${ }^{3}$ Enterprise bonds are the earliest type of corporate bonds issued in China. Many enterprise bonds trade in both the interbank market and exchange markets. They are usually issued by SOEs and guaranteed by one of the state-banks. Corporate bonds are issued by listed companies and traded in exchange. Listed company bonds are real credit bonds without bank guarantees. Commercial paper and mid-term note (MTN) are solely traded in the interbank market and usually issued by large corporations with good standing. Financial bonds are traded in the interbank market and issued by banks, finance companies, and other financial institutions.
} 
AA or better. More than two thirds of bonds are rated AA or higher $(21,032$ out of 29,388). Only 15 issues are rated BBB or lower. $70 \%$ bonds issued by central SOE and $75 \%$ issued by local SOE receive AA ratings or higher. However, only $49 \%$ bonds issued by Non-SOEs receive AA ratings or higher. The average bond yields of each subcategory are $4.30 \%, 5.44 \%, 6.20,7.22 \%, 4.44 \%, 4.17 \%$ and 6.53 , respectively.

In Table 4, we show the summary statistics of our sample. SOEs tend to have lower bond yield (including offering yield, bond trade yield and yield spread) than non-SOEs. The average rating of SOE bonds is 5.3 , while the average rating is 4.2 for non-SOE bonds. The average firm size (total assets) of CG-SOEs and LG-SOEs are $\$ 6.7$ billion and $\$ 12.7$ billion; the average total assets of non-SOEs is only $\$ 2.2$ billion. In addition, SOEs are more profitable in term of return on assets and return on equity. The equity volatility is estimated using the 252 days stock daily return.

\section{Empirical Results}

In this section, we examine the implicit government guarantees of state-owned enterprises using corporate bond data. First, we examine the relation between bond yield spread and issuer type. Second, following the model described before, we use equity volatility beta as a proxy of implicit guarantee to estimate the size of implicit guarantee. In contrast, we also look at the agency cost of implicit government guarantees by examining their operating and stock performance

\subsection{Implicit guarantee and yield spread}

We begin our empirical analysis by examining the relation between the yield spread and issuer type. Investors have long held the view that the Chinese government would never let large SOEs default since such an event might trigger severe instability 
or collapse an entire industry or economy. Livingston, Poon and Zhou (2018) find that bonds issued by SOEs receive higher ratings than those by the non-SOEs. We ask whether SOEs can borrow debts at a lower cost than non-SOEs by controlling for firm specific, bond specific and macroeconomic variables. We include a list of independent variables used in Collin-Dufresne et al. (2001), Campbell and Taksler (2003), and Chen, Lesmond and Wei (2007). The regression model is specified as follows:

$$
\mathrm{YS}_{i j t}=\alpha_{0}+\beta_{1} \mathrm{IGG}_{j}+\beta_{2} \text { Control }+\epsilon
$$

where $\mathrm{YS}_{i j t}$ is the bond yield spread of bond $\mathrm{i}$ by firm $\mathrm{j}$. The implicit government guarantee effect is estimated by the bond issuer type dummy. We also control a series of independent variables. We consider bond-specific variables, including credit rating, years to maturity and issuance amount. We also include two accounting variables: operating income to sales and long-term debt to assets. To control for macroeconomic variables, we use 1-year treasury rate, the difference between the 10- and 2- year Treasury rates.

Table 5 reports regression results of bond yield spread on bond specific variables and macroeconomic variables. This allows us to use a large bond sample with 29,090 bond issues of the bond offering sample and 85,887 quarterly observations of the bond trading sample. We perform industry and year fixed effect regression to control for industry and year influences on yield. In the first two columns, we use the bond offering sample, which include bonds are newly offered during the sample period. In the next two columns, the regression is estimated using bond trading data. There are three main issuer types: CG-SOE, LG- SOE and non-SOE. CG-SOE is a state owned enterprise (SOE) by Chinese central government; LG- SOE is a state owned enterprise 
(SOE) by Chinese local government; and Non-SOE is an issuer not owned by the government. As we discussed earlier, we expect the yield of bonds issued by SOEs is lower than that of non-SOE because of implicit government guarantees. Further, yields of CG-SOE are even lower than that of LG-SOE because these bonds are backed by the central government. We consider bond specific variables: credit ratings, years to maturity and outstanding amount. Bond ratings are divided into 7 categories and we assign integer numbers to the credit rating, $\mathrm{AAA}=6, \mathrm{AA}+=5, \mathrm{AA}=4, \mathrm{AA}-=3, \mathrm{~A}+$ to $\mathrm{A}-$ $=2, \mathrm{BBB}+$ or below $=1$, not rated $=0$. Yield spreads are generally negatively related to credit ratings. We also include macroeconomic variables: 1 year treasury rate and the treasury slope, which is the difference between the 10 year and 2 year Treasury rates.

Table 5 show the regression results. In column 1 and 3, we use the full sample which includes bonds with all issue types and bond ratings. We find that yield of nonSOE is 103 bps higher than that of CG-SOE after controlling for bond characteristics and macroeconomic variables. In addition, the yield of LG-SOE is about 23 bps point higher than that of CG-SOE. This is consistent with our expectation that SOEs have lower default risk and lower yield spread due to the government support. In column 2 and 4, we use a subsample of enterprise bonds, corporate bonds and medium-term note (MTN), which receive investment grade ratings. The results are consistent with the previous finding. We find SOE bonds tend to have lower yield spread than non-SOE bonds. It may be noted that the coefficient on rating is negative and significant, suggesting that bond yield is negatively related to the credit rating. Issuance amount, which is considered as the measure of liquidity, is negatively related to the yield spread. 
In Table 6, we control for both firm and bond specific variables. Since firm specific variables are only available to public listed firms, we end up with a much smaller sample. We have 4975 bond issues in the bond offering sample and 11055 quarter bond trading observations in the bond trading sample. In column 1 and 2, we show the regression results of all bonds issued by public listed firms. Noticeably, the yield spread of non-SOE bonds is 85 bps higher than that of CG-SOE bonds after controlling for bond, firm and macroeconomic variables. Interestingly, in regression 2 , equity volatility is not related to yield spread, suggesting that equity volatility has been priced in yield spread or might be explained by other control variables. We further examine the relation between yield spread and issuer type using bond trading data. The most telling finding is the consistent significance of the issuer type variables. The coefficients on non-SOE and LG-SOE variables are positive and significant, suggesting a higher yield than that of CG-SOE bonds. Consistent with CollinDufresne, Goldstein, and Martin (2001) and Chen, Lesmond and Wei (2007), we find that leverage (long term debt to assets) is positively related to yield spread and income to sales are negatively related to the offering yield.

\subsection{Implicit guarantee and yield spread sensitivity to equity volatility}

Following the simple model laid out in the section 3, we use the sensitivity of yield spread to equity volatility to quantify the implicit government guarantee. The sensitivity is estimated as follows:

$$
\mathrm{YS}_{i j t}=\alpha_{0}+\beta_{1} \text { Evol }_{j}+\beta_{2} \text { Rating }+\beta_{3} \text { Size }+\epsilon
$$

where $\mathrm{YS}_{i j t}$ is the bond yield spread of bond $\mathrm{i}$ by firm $\mathrm{j}$. The equity volatility is estimated using past 252 daily stock return from CSMAR. We further control for bond 
rating and firm size, which is estimated by the natural log of total assets. Betas are estimated over rolling 4-year periods for each bond and then used in the crosssectional regression. We estimate betas for each corporate bonds that has at least 4 quarterly observations over the 16-quarter window.

In the empirical framework section, we propose the idea that IGG reduce the sensitivity of a firm's bond yields to volatility of the firm's equity. As a result, we quantify the IGG as the negative equity volatility betas.

$$
\mathrm{IGG}=-\widehat{\beta_{1}}
$$

where $\widehat{\beta_{1}}$ is estimated from Eq. (7).

In Table 4, the average betas of central SOEs and local SOEs are 0.423 and 0.486, respectively; while the average betas of non-SOEs is 0.956 . We further examine whether yield spread sensitivity can capture the implicit government guarantee effect. To do so, we estimate the following regression:

$$
\mathrm{IGG}_{\mathrm{j}}=\alpha_{0}+\beta_{1} \text { Issuer Dummy }_{j}+\text { Control }+\epsilon
$$

If IGG is indeed a good proxy of implicit guarantee, non-SOEs would have a high yield sensitivity to equity volatility, while SOEs tend to have relatively low yield sensitivity. The estimated results are reported in Table 7. As expected, non-SOE is associated with lower IGG, i.e. higher yield spread sensitivity. The results remain strong as we use various regression models, including ordinary least square (OLS), random effect, and fixed effect. 


\subsection{Agency Cost and SOEs}

With the implicit government guarantees, SOEs can issue bonds at a lower financing cost. On the other hand, IGG may cause high agency cost of SOEs. Debtholders are less concerned with corporate defaults risk because government tends to bail out SOEs when they are financial distress. In addition, the policy burden, incompetence of corporate managers and ill-functioning compensation scheme have caused a significantly high agency costs, which are important contributors to SOE's inefficiency and low productivity.

We examine the operation performance in terms of operating income to sales and return on assets. For each issuer type, we calculate the median operating ratio each year over the sample period from 2006-2016. Figure 1 shows the operating profitability ratios over the sample period. In figure 1.1, the median operating income to sale of non-SOEs (8.03) is significantly higher than that of CG-SOE (5.33) and LG-SOE (6.04), suggesting that nonSOEs are more efficiency in operating income to sales. Similar, we find similar patterns in Figurer 1.2. But the difference of return on assets between SOEs and no-SOEs is narrowing down with the widest spread during 2007-2010. More interestingly, we notice that the difference of return on equity between SOEs and non-SOEs is much smaller in recent years.

We further examine the implicit government guarantee effect on corporate operating profitability. The regression model is specified as follows:

$$
\mathrm{OP}_{j t}=\alpha_{0}+\beta_{1} \mathrm{IGG}_{j}+\beta_{2} \text { Control }+\epsilon
$$

where, $\mathrm{OP}$ is estimated by three measures of operating profitability: operating income to sales return on assets, and return on equity. We use issue type dummy and yield spread sensitivity as proxy of IGG. We also control for yield spread, leverage (long term debt to assets), natural $\log$ of asset, natural $\log$ of market capitalization. Table 8 reports regression results. The coefficients in column 1, 3 and 5 on non-SOE and LG-SOE dummy are positive 
and significant, suggesting non-SOEs and LG-SOE are associated with higher operating profitability ratios than CG-SOEs. It is worth noting that non-SOEs tend to have a much better operating performance after controlling for firm and bond specific variables. For example, the operating income to sales is $6.14 \%$ higher than that of central SOEs. In column 2, 4, and 6, coefficients of Beta are negative and significant which shows that SOEs have lower operational profitability when the IGG is high. Consistent with the evidence in Section 5.2, we show that equity volatility Beta is a good proxy to capture the IGG effect. Further, we study the stock performance. Similarly, we calculate the median annual stock return each year for each issuer type. However, in figure 2, we find the annual stock return of SOEs and non-SOEs move almost synchronically over the sample period. Stock return movement reflects the intrinsic value of underlying stock, which is associated with the firm's operating efficiency. Despite the relatively low operating performance of SOEs, the stock tends to perform similarly non-SOEs. We attribute the synchronically stock performance to the implicit government guarantees. Then we examine the implicit government guarantee effect on stock performance. We estimate the following regression:

$$
\operatorname{Ret}_{j t}=\alpha_{0}+\beta_{1} \mathrm{IGG}_{j}+\beta_{2} \text { Control }+\epsilon
$$

where, ret is the stock return in quarter t. We include the IGG proxy (issuer type dummy and yield spread sensitivity), bond and firm-specific characteristics variables. Generally, stock performance is the mirror of the operating performance. In Table 9, we examine the relationship between stock return and IGG proxy. One might expect that investors might perceive the implicit government guarantee. Thus, IGG is associated with positive stock performance. Column 1 is the base model with only bond and firm specific variables. Column 2 we use the issuer type as IGG proxy, while in column 3 we use the equity volatility beta. Interestingly, we show that coefficient on non-SOE dummy is negative and significant, suggesting that non-SOE is associated with negative stock performance. The coefficient on 
LG-SOE is negative but insignificant. Central SOEs are backed by the central government with a stronger commitment to bail out the troubled SOEs, but there is no significant difference between LG-SOE and CG-SOE. The equity volatility beta is positive and significant at 5\% level, suggesting that Non-SOE firms have poorer stock performance than SOEs, and the less sensitive to equity volatility the higher stock performance. These facts may confirm our thoughts that stock market investors have expectation of implicit government guarantee for SOEs, which results in the higher SOEs stock performance and the contrary operational profits simultaneously.

\section{Conclusion}

We examine the determinants of the pricing of Chinese corporate bonds and potential agency costs of implicit government guarantees. We find strong evidence that SOEs enjoy lower debt financing cost. Yield spread of CG-SOE bonds is 14 bps and 85 bps lower than that of LG-SOE and non-SOE, respectively. Our results remain consistent and strong when we control for a series bond-specific, firm-specific and macroeconomic variables.

Building a simple framework which considers the implicit government guarantee as the put option, we use yield spread sensitivity to equity volatility as an proxy for implicit government guarantee. We show that yield spread sensitivity can largely capture the effect of implicit government guarantee. Moreover, we examine the agency cost of implicit government guarantees. SOEs tend to underperform non-SOEs in terms of operating income to sales, return on assets and return on equity. Despite the difference in operating performance, IGG is associated with positive stock performance. 


\section{References}

Aivazian, V.A., Y. Ge, J. Qiu, 2005, "Can corporatization improve the performance of state-owned enterprises even without privatization?" Journal of Corporate Finance 11 (5): 791-808

Ang, A., J. Bai, and H. Zhou, 2016, “The great wall of debt: real estate, political risk, and Chinese local government credit spreads”, working paper, SSRN 2603022.

Brunnermeier, M., M. Sockin, and W. Xiong, 2017, “China's gradualistic economic approach: Does it work for financial development?" Forthcoming in American Economic Review Papers \& Proceedings.

Campbell, J. Y. and G. B. Taksler, 2003, "Equity Volatility and Corporate Bond Yields", Journal of Finance 58: 2321-50.

Chen, L., D. Lesmond, and J. Wei, 2007, "Corporate Yield Spread and Bond Liquidity", Journal of Finance 62: 119-149.

Collin-Dufresne, P., R. Goldstein, and S. Martin, 2001, "The determinants of credit spread changes", Journal of Finance 56, 2177-2207.

Jensen, M., 1986, “Agency Costs of Free Cash Flow, Corporate Finance, and Takeovers," American Economic Review, 76: 323-29.

Jensen, M.C. and W.H. Meckling, 1976, “Theory of the firm: managerial behavior, agency costs and ownership structure", Journal of Financial Economics 3: 305-360.

Ke, Q., 2008, “Are State-Owned Companies Underperforming? A Case Study of Chinese Listed Property Companies", Journal of Real Estate Literature 16 (2): pp. 183-200. 
Liao, L., B. Liu and H. Wang, 2014, “China's secondary privatization: Perspectives from the Split-Share Structure Reform", Journal of Financial Economics 113, 500-518. Livingston, M., W. Poon, and L. Zhou, 2018, “Are Chinese credit ratings relevant? A study of the Chinese bond market and credit rating industry", Journal of Banking and Finance 87: 216-232.

Megginson, W., and Jeffry M. Netter, 2001, "From state to market: A survey of empirical studies on privatization", Journal of Economic Literature 39, 321-389.

Merton, R., 1974 "On the pricing of Corporate Debt: The Risk Structure of Interest Rates", Journal of Finance, 29: 449-470.

O'Hara, M., and W. Shaw, 1990, "Deposit Insurance and Wealth Effects: The Value of Being 'Too Big to Fail'." Journal of Finance 45(5): 1587-1600.

S\&P, 2009. Chinese bond market - an introduction. Standards and Poor's, March 2009. Ueda, K., and di Mauro, B., 2013, "Quantifying Structural Subsidy Values for Systemically Important Financial Institutions,” Journal of Banking \& Finance 37(10): $3830-3842$.

Zhou, M., and X. Wang, 2000, "Agency cost and the crisis of China's SOE", China Economic Review 11: 297-317. 


\section{Table 1. Numbers and Amount of Bonds Issue in China}

This tables shows the number of public bond issues by types of issuers from 2006 - 2016. CGSOEs are state-owned enterprises of central government of China. LG-SOEs are state-owned enterprises of the Chinese local governments. Non-SOEs are issuers not owned by the nonSOEs. Majority of the non-SOEs are private companies. The issue amount is nominated in the chinese currency (CNY) and in thousand.

\begin{tabular}{lcccccccc}
\hline \multicolumn{7}{c}{ Number of Bond Issuers } & & \multicolumn{3}{c}{ Issue Amount } \\
\hline Year & CG-SOE & LG-SOE & Non-SOE & All & CG-SOE & LG-SOE & Non-SOE & All \\
\hline 2006 & 116 & 150 & 75 & 297 & 200,730 & 135,710 & 16,250 & 352,690 \\
2007 & 95 & 165 & 101 & 298 & 221,670 & 164,600 & 22,310 & 408,580 \\
2008 & 128 & 186 & 96 & 346 & 468,130 & 231,910 & 27,550 & 727,590 \\
2009 & 221 & 443 & 99 & 715 & 873,298 & 656,890 & 48,885 & $1,579,073$ \\
2010 & 226 & 601 & 140 & 920 & 718,130 & 724,580 & 59,765 & $1,502,475$ \\
2011 & 321 & 854 & 318 & 1440 & $1,030,570$ & 999,180 & 199,500 & $2,229,250$ \\
2012 & 568 & 1752 & 641 & 2895 & $1,873,030$ & $1,935,660$ & 320,266 & $4,128,956$ \\
2013 & 625 & 1836 & 877 & 3233 & $1,685,580$ & $2,030,428$ & 414,089 & $4,130,097$ \\
2014 & 832 & 3385 & 1023 & 5084 & $1,912,974$ & $3,493,296$ & 511,459 & $5,917,729$ \\
2015 & 1034 & 4006 & 1428 & 6282 & $2,391,545$ & $3,836,279$ & $1,116,025$ & $7,343,849$ \\
2016 & 1118 & 5141 & 1786 & 7878 & $2,600,986$ & $4,846,987$ & $1,608,899$ & $9,056,872$ \\
Total & 5284 & 18519 & 6584 & 29388 & $13,976,642$ & $19,055,520$ & $4,344,998$ & $37,377,160$ \\
\hline
\end{tabular}




\section{Table 2. Bond Yields and Bond Issue Types}

This table shows the number of bond issues and bond yield by different types of bond issues from 2006 - 2016. CG-SOEs are state-owned enterprises of central government of China. LG-SOEs are state-owned enterprises of the Chinese local governments. Non-SOEs are issuers not owned by the non-SOEs. Majority of the non-SOEs are private companies. There are five types of non-governmental public bonds: enterprise bonds, corporate bonds, medium term notes (MTN), private placement notes (PPN), and commercial paper. Bond yield are the yield at the bond offering.

\begin{tabular}{lcccccccc}
\hline & \multicolumn{4}{c}{ Number of Bond Issues } & \multicolumn{5}{c}{ Bond Yield } \\
\hline \multirow{2}{*}{ Issue Type } & CG- & LG- & Non- & \multirow{2}{*}{ All } & CG- & LG- & Non- & \multirow{2}{*}{ All } \\
\hline Enterprise Bonds & SOE & SOE & SOE & & SOE & SOE & SOE & \\
Corporate Bonds & 256 & 4876 & 181 & 5313 & 4.79 & 6.15 & 6.58 & 5.94 \\
Medium Term Notes & 945 & 2781 & 1760 & 4926 & 4.06 & 5.19 & 5.86 & 5.22 \\
Private Placement & 2791 & 694 & 4427 & 4.41 & 5.17 & 5.46 & 4.87 \\
Notes & 461 & 2643 & 607 & 3711 & 5.33 & 6.06 & 6.57 & 6.00 \\
Commercial Paper & 3061 & 5220 & 2238 & 10519 & 3.87 & 4.27 & 4.80 & 4.12 \\
\hline
\end{tabular}




\section{Table 3. Bond Yields and Ratings Groups}

This Table reports the number of bond issues by rating and issuer types. CG-SOEs are state-owned enterprises of central government of China. LG-SOEs are stateowned enterprises of the Chinese local governments. Non-SOEs are issuers not owned by the non-SOEs. Majority of the non-SOEs are private companies. Bond ratings are divided into 7 categories: $\mathrm{AAA}, \mathrm{AA}+, \mathrm{AA}, \mathrm{AA}-, \mathrm{A}(\mathrm{A}+$ to $\mathrm{A}-)$, noninvestment grade $(\mathrm{NI})$, which is rated $\mathrm{BBB}+$ or lower, and not rated $(\mathrm{NR})$.

\begin{tabular}{lcccccccc}
\hline \multicolumn{4}{c}{ Number of Bond Issuers } & \multicolumn{4}{c}{ Yield } \\
& CG- & LG- & Non- & \multirow{2}{*}{ All } & CG- & LG- & Non- & \multirow{2}{*}{ All } \\
& SOE & SOE & SOE & & SOE & SOE & SOE & \\
\hline AAA & 2834 & 3113 & 258 & 6205 & 4.10 & 4.65 & 4.50 & 4.30 \\
AA+ & 522 & 4206 & 800 & 5528 & 4.88 & 5.52 & 5.38 & 5.44 \\
AA & 260 & 6463 & 1919 & 8642 & 5.33 & 6.20 & 6.32 & 6.20 \\
AA- & 22 & 320 & 315 & 657 & 7.29 & 7.02 & 7.45 & 7.22 \\
A & 1552 & 3545 & 1822 & 6919 & 4.09 & 4.56 & 4.84 & 4.44 \\
NI & 2 & 1 & 12 & 15 & 3.33 & 10.00 & 4.82 & 4.17 \\
NR & 92 & 871 & 459 & 1422 & 5.46 & 6.74 & 6.66 & 6.53 \\
\hline Total & 29388 & 5284 & 18519 & 5585 & & & &
\end{tabular}


Table 4. Summary Statistics

This table shows summary statistics of bond and firm variables. We include bond offering yield, trading yield, yield spread and credit ratings. Yield spread is then defined as the difference between the bond yield and the associated yield of the treasury yield curve at the same maturity. Bond ratings are divided into 7 categories and we assign integer numbers to the credit rating, $\mathrm{AAA}=6, \mathrm{AA}+=5, \mathrm{AA}=4, \mathrm{AA}-=3, \mathrm{~A}+$ to $\mathrm{A}$ $=2, \mathrm{BBB}+$ or below $=1$, not rated=0. We also include total assets (in millions), market cap (in millions), which is the market value of equity, income to sales, return on assets, return on equity, long term debt to assets, daily equity volatility, quarterly stock return and yield spread sensitivity to equity volatility (Beta).

\begin{tabular}{lcccccccc}
\hline & \multicolumn{2}{c}{ Full Sample } & \multicolumn{2}{c}{ CG-SOE } & \multicolumn{2}{c}{ LG-SOE } & \multicolumn{2}{c}{ Non-SOE } \\
\cline { 2 - 8 } \multicolumn{1}{c}{ VARIABLES } & Mean & Std Dev & Mean & Std Dev & Mean & Std Dev & Mean & Std Dev \\
\hline Offering Yield & 5.82 & 1.28 & 5.15 & 1.04 & 5.51 & 1.11 & 6.21 & 1.31 \\
Yield & 5.46 & 1.29 & 4.81 & 0.88 & 5.04 & 1.06 & 5.91 & 1.35 \\
Yield Spread & 2.49 & 1.26 & 1.67 & 0.77 & 2.00 & 0.96 & 3.02 & 1.30 \\
Rating & 4.63 & 0.86 & 5.33 & 0.83 & 4.98 & 0.81 & 4.21 & 0.64 \\
Total Assets & $3,444.9$ & $6,767.3$ & $9,087.0$ & $12,749.0$ & $2,746.2$ & $3,089.8$ & $2,249.7$ & $4,901.4$ \\
Market Cap & $1,882.7$ & $2,263.6$ & $3,454.6$ & $3,957.7$ & $1,513.8$ & $1,721.7$ & $1,656.3$ & $1,619.6$ \\
Income to Sales & 8.55 & 12.80 & 7.40 & 10.80 & 9.17 & 15.15 & 8.50 & 11.73 \\
ROA & 3.82 & 2.91 & 3.41 & 2.45 & 3.19 & 2.43 & 4.33 & 3.20 \\
ROE & 5.19 & 5.12 & 4.98 & 4.30 & 3.87 & 4.59 & 6.05 & 5.47 \\
LT Debt/ Assets & 0.21 & 0.11 & 0.23 & 0.13 & 0.24 & 0.10 & 0.18 & 0.09 \\
Equity Volatility & 3.98 & 0.56 & 3.90 & 0.62 & 3.99 & 0.53 & 4.01 & 0.56 \\
Return & 3.27 & 8.93 & 3.76 & 7.84 & 3.09 & 6.53 & 3.25 & 10.39 \\
Beta & 0.67 & 1.57 & 0.42 & 1.26 & 0.49 & 1.09 & 0.96 & 2.00 \\
\hline
\end{tabular}


Table 5. Regression of Bond Yields on Bond Specific Variables

This table reports the regression results of bond yield on issuer type, bond specific variables and macroeconomic variables. CG-SOE is a state owned enterprise (SOE) by Chinese central government; LGSOE is a state owned enterprise (SOE) by Chinese local government; and Non-SOE is an issuer not owned by the government. We consider bond specific variables: credit ratings, years to maturity and outstanding amount. Bond ratings are divided into 7 categories and we assign integer numbers to the credit rating, $\mathrm{AAA}=6, \mathrm{AA}+=5$, $\mathrm{AA}=4, \mathrm{AA}-=3, \mathrm{~A}+$ to $\mathrm{A}-=2, \mathrm{BBB}+$ or below $=1$, not rated $=0$. We also include macroeconomic variables: 1 year treasury rate and the treasury slope, which is the difference between the 10 year and 2 year Treasury rates. We use two different samples: the full sample and a subsample with investment grade enterprise bonds, corporate bonds, and MTN. We use robust standard error to calculate $t$ value. Tstatistics are presented in parentheses. The industry is the fixed effect. $*$, ** or $* * *$ signifies significance at the $10 \%, 5 \%$, or $1 \%$ level, respectively.

\begin{tabular}{|c|c|c|c|c|}
\hline \multirow[b]{2}{*}{ VARIABLES } & \multicolumn{2}{|c|}{ Offering Yield Spread } & \multicolumn{2}{|c|}{ Trading Yield Spread } \\
\hline & (1) & (2) & (3) & (4) \\
\hline LG-SOE & $\begin{array}{c}0.261 * * * \\
(16.56)\end{array}$ & $\begin{array}{c}0.485 * * * \\
(11.92)\end{array}$ & $\begin{array}{c}0.226 * * * \\
(17.21)\end{array}$ & $\begin{array}{c}0.276 * * * \\
(9.51)\end{array}$ \\
\hline Non-SOE & $\begin{array}{c}1.022 * * * \\
(46.05)\end{array}$ & $\begin{array}{c}1.266^{* * *} \\
(28.05)\end{array}$ & $\begin{array}{c}1.039 * * * \\
(52.60)\end{array}$ & $\begin{array}{c}1.177 * * * \\
(37.50)\end{array}$ \\
\hline Rating & $\begin{array}{c}-0.054 * * * \\
(-11.05)\end{array}$ & $\begin{array}{c}-0.364 * * * \\
(-33.87)\end{array}$ & $\begin{array}{c}-0.460 * * * * \\
(-86.03)\end{array}$ & $\begin{array}{c}-0.351 * * * \\
(-43.13)\end{array}$ \\
\hline Maturity (years) & $\begin{array}{c}0.016 * * * \\
(6.24)\end{array}$ & $\begin{array}{c}-0.056 * * * \\
(-8.46)\end{array}$ & $\begin{array}{c}-0.003 * * * \\
(-8.33)\end{array}$ & $\begin{array}{c}0.009 * * * \\
(13.66)\end{array}$ \\
\hline $\log ($ Amount $)$ & $\begin{array}{c}-0.385 * * * \\
(-63.14)\end{array}$ & $\begin{array}{c}-0.198 * * * \\
(-19.72)\end{array}$ & $\begin{array}{c}-0.274 * * * \\
(-38.71)\end{array}$ & $\begin{array}{c}-0.403 * * * \\
(-41.60)\end{array}$ \\
\hline $\mathrm{T}-1$ year & $\begin{array}{c}0.730 * * * \\
(59.12)\end{array}$ & $\begin{array}{c}0.639 * * * \\
(33.70)\end{array}$ & $\begin{array}{c}0.331 * * * \\
(45.44)\end{array}$ & $\begin{array}{c}0.369 * * * \\
(44.71)\end{array}$ \\
\hline Tslope & $\begin{array}{c}0.871 * * * \\
(35.15)\end{array}$ & $\begin{array}{c}0.952 * * * \\
(25.62)\end{array}$ & $\begin{array}{c}0.813 * * * \\
(53.64)\end{array}$ & $\begin{array}{c}1.064 * * * \\
(55.78)\end{array}$ \\
\hline Constant & $\begin{array}{c}2.467 * * * \\
(41.75)\end{array}$ & $\begin{array}{c}3.188 * * * \\
(37.20)\end{array}$ & $\begin{array}{c}4.964 * * * \\
(80.42)\end{array}$ & $\begin{array}{c}4.879 * * * \\
(60.78)\end{array}$ \\
\hline Observations & 29,090 & 11,555 & 85,887 & 67,965 \\
\hline R-squared & 0.367 & 0.448 & 0.265 & 0.180 \\
\hline
\end{tabular}


Table 6. Regression of Yield Spread on Implicit Government Guarantees

This table reports the regression results of yield spread on issuer type, equity volatility, bond specific, firm specific variables and macroeconomic variables. CGSOE is a state owned enterprise (SOE) by Chinese central government; LG-SOE is a state owned enterprise (SOE) by Chinese local government; and Non-SOE is an issuer not owned by the government. We consider bond specific variables: credit ratings, years to maturity and natural log of outstanding amount; firm specific variables: longterm debt to assets and operating income to sales. We also include macroeconomic variables: 1 year treasury rate and the treasury slope, which is the difference between the 10 year and 2 year Treasury rates. We use two different samples: bond offering sample and bond trading sample. We use robust standard error to calculate t value. Tstatistics are presented in parentheses. The industry is the fixed effect. *,** or *** signifies significance at the $10 \%, 5 \%$, or $1 \%$ level, respectively.

\begin{tabular}{|c|c|c|c|c|c|}
\hline \multirow[b]{2}{*}{ Variables } & \multicolumn{2}{|c|}{ Offering Yield Spread } & \multicolumn{3}{|c|}{ Trading Yield Spread } \\
\hline & (1) & (2) & (3) & (4) & (5) \\
\hline LG-SOE & $\begin{array}{c}0.140 * * * \\
(4.21)\end{array}$ & & $\begin{array}{c}0.133 * * * \\
(5.20)\end{array}$ & & \\
\hline Non-SOE & $\begin{array}{c}0.853 * * * \\
(20.65)\end{array}$ & & $\begin{array}{c}0.730 * * * \\
(21.53)\end{array}$ & & \\
\hline Evol & & $\begin{array}{l}0.016 \\
(1.12)\end{array}$ & & $\begin{array}{c}0.074 * * * \\
(3.99)\end{array}$ & \\
\hline IGG & & & & & $\begin{array}{c}-0.024 * * \\
(-2.44)\end{array}$ \\
\hline Rating & $\begin{array}{c}0.038 * * * \\
(3.78)\end{array}$ & $\begin{array}{l}-0.005 \\
(-0.52)\end{array}$ & $\begin{array}{c}-0.497 * * * \\
(-28.56)\end{array}$ & $\begin{array}{c}-0.656 * * * \\
(-40.14)\end{array}$ & $\begin{array}{c}-0.639 * * * \\
(-33.78)\end{array}$ \\
\hline $\log ($ Amount $)$ & $\begin{array}{c}-0.322 * * * \\
(-19.78)\end{array}$ & $\begin{array}{c}-0.402 * * * \\
(-24.09)\end{array}$ & $\begin{array}{c}-0.190 * * * \\
(-12.78)\end{array}$ & $\begin{array}{c}-0.144 * * * \\
(-8.85)\end{array}$ & $\begin{array}{c}-0.150 * * * \\
(-8.23)\end{array}$ \\
\hline Maturity & $\begin{array}{c}-0.046^{* * *} \\
(-7.61)\end{array}$ & $\begin{array}{c}-0.022 * * * \\
(-3.50)\end{array}$ & $\begin{array}{c}-0.014 * * * \\
(-11.84)\end{array}$ & $\begin{array}{c}-0.014 * * * \\
(-10.67)\end{array}$ & $\begin{array}{c}-0.014 * * * \\
(-9.54)\end{array}$ \\
\hline LT Debt to Assets & $\begin{array}{c}1.026 * * * \\
(7.67)\end{array}$ & $\begin{array}{c}1.033 * * * \\
(7.26)\end{array}$ & $\begin{array}{c}0.853 * * * \\
(7.92)\end{array}$ & $\begin{array}{c}0.736^{* * *} \\
\quad(6.20)\end{array}$ & $\begin{array}{c}0.846^{* * *} * \\
(6.18)\end{array}$ \\
\hline Income to Sales & $\begin{array}{c}-0.012 * * * \\
(-8.72)\end{array}$ & $\begin{array}{c}-0.007 * * * \\
(-4.92)\end{array}$ & $\begin{array}{c}-0.020 * * * \\
(-18.79)\end{array}$ & $\begin{array}{c}-0.013 * * * \\
(-13.78)\end{array}$ & $\begin{array}{c}-0.015 * * * \\
(-13.83)\end{array}$ \\
\hline $\mathrm{T}-1$ year & $\begin{array}{c}0.799 * * * \\
(26.87)\end{array}$ & $\begin{array}{c}0.717 * * * \\
(21.42)\end{array}$ & $\begin{array}{c}0.235 * * * \\
(10.44)\end{array}$ & $\begin{array}{c}0.222^{* * * *} \\
(8.49)\end{array}$ & $\begin{array}{c}0.245^{* * *} \\
(8.77)\end{array}$ \\
\hline Tslope & $\begin{array}{c}0.968 * * * \\
(17.44)\end{array}$ & $\begin{array}{c}0.774 * * * \\
(13.19)\end{array}$ & $\begin{array}{c}0.782 * * * \\
(17.34)\end{array}$ & $\begin{array}{c}0.750 * * * \\
(15.38)\end{array}$ & $\begin{array}{c}0.711 * * * \\
(12.35)\end{array}$ \\
\hline Constant & $\begin{array}{c}1.290 * * * \\
(8.04)\end{array}$ & $\begin{array}{c}2.528 * * * \\
(13.46)\end{array}$ & $\begin{array}{c}4.892 * * * \\
(35.68)\end{array}$ & $\begin{array}{c}5.383 * * * \\
(34.02)\end{array}$ & $\begin{array}{c}5.572 * * * \\
(35.49)\end{array}$ \\
\hline Observations & 4,972 & 4,972 & 11,055 & 8,551 & 7,016 \\
\hline R-squared & 0.361 & 0.286 & 0.413 & 0.382 & 0.381 \\
\hline
\end{tabular}




\section{Table 7. Equity Sensitivity and Implicit Government Guarantees}

The dependent variables are estimated over rolling 4-year periods for each bond and then used in the cross-sectional regression. We estimate betas for each corporate bonds that has at least 4 quarterly observations over the 16-quarter window. We include the bond issuer dummy, log of total assets, long term debt to assets, income to sales, and credit ratings. We estimate using OLS, random effect and firm fixed effect. We use robust standard error to calculate t value. Tstatistics are presented in parentheses. The industry is the fixed effect. $*, * *$ or $* * *$ signifies significance at the $10 \%, 5 \%$, or $1 \%$ level, respectively

\begin{tabular}{lccc}
\hline & $(1)$ & $(2)$ & $(3)$ \\
VARIABLES & OLS & RE & FE \\
\hline \multirow{2}{*}{ LG-SOE } & & & \\
& $-0.235 * * *$ & $-0.206 * *$ & $-0.140 *$ \\
Non-SOE & $(-2.87)$ & $(-2.25)$ & $(-1.68)$ \\
& $-0.404 * * *$ & $-0.352 * * *$ & $-0.238^{* *}$ \\
Log (Assets) & $(-5.13)$ & $(-3.66)$ & $(-2.22)$ \\
& $0.129 * * *$ & $0.128 * * *$ & $0.180 * * *$ \\
LT Debt/Assets & $(4.29)$ & $(4.67)$ & $(6.78)$ \\
& -0.309 & -0.297 & -0.265 \\
Income to Sales & $(-1.10)$ & $(-1.13)$ & $(-0.86)$ \\
& -0.003 & -0.003 & $-0.005 *$ \\
Rating & $(-1.28)$ & $(-1.33)$ & $(-1.70)$ \\
& $0.140 * * *$ & $0.140 * * *$ & $0.113 * *$ \\
Constant & $(2.64)$ & $(2.93)$ & $(2.41)$ \\
& $0.130 * *$ & $0.210 *$ & $3.606 * * *$ \\
Observations & $(1.97)$ & $(1.96)$ & $(10.15)$ \\
R-squared & 7,033 & 7,016 & 7,016 \\
\hline
\end{tabular}


Table 8. Regression of IGG and Operating Profitability

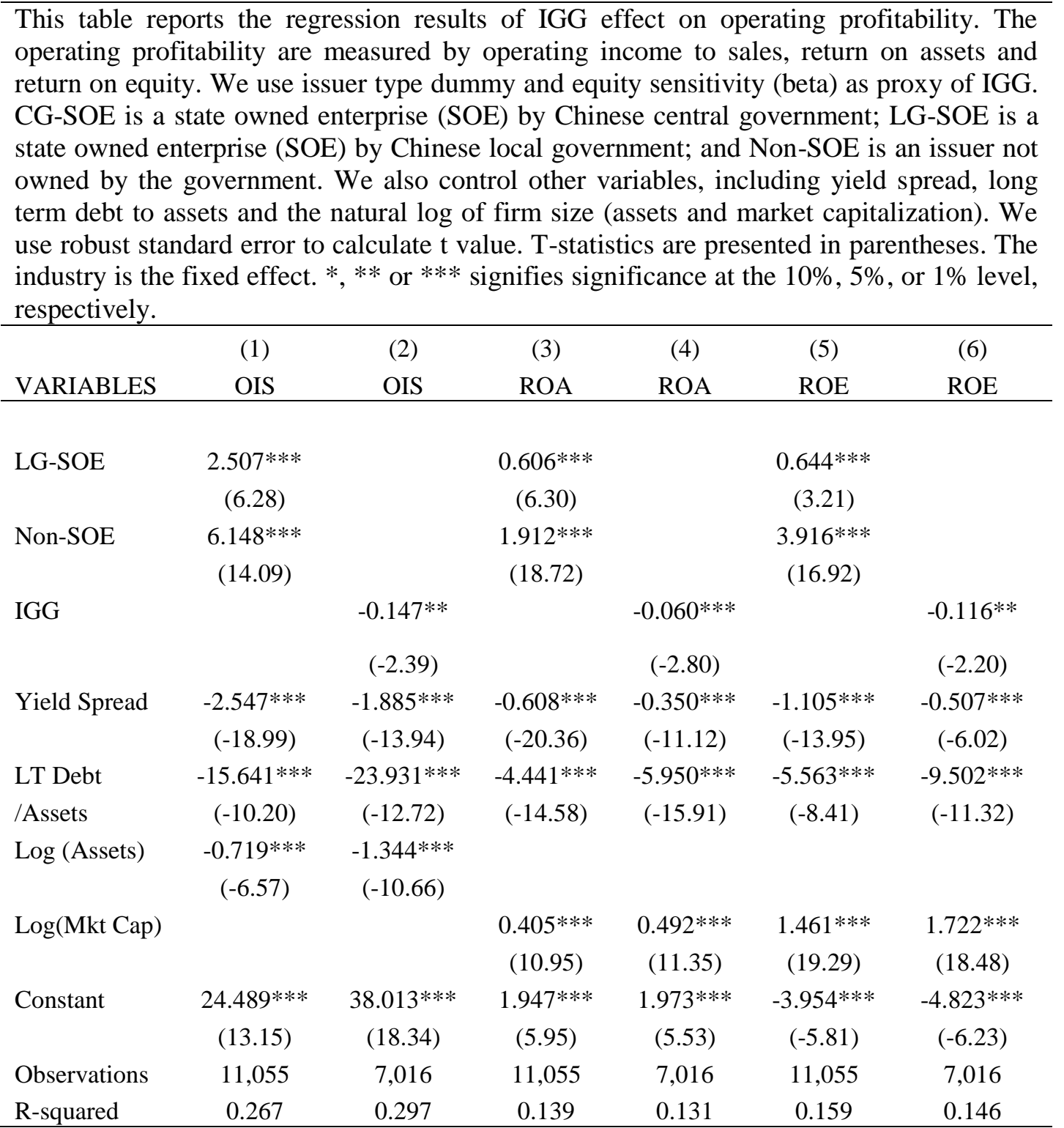




\section{Table 9. Regression Results of IGG Effect on Stock Performance}

This table reports the regression results of IGG effect on stock performance. We use issuer type dummy and sensitivity of yield spread to equity (beta) as proxy of IGG. CG-SOE is a state owned enterprise (SOE) by Chinese central government; LG-SOE is a state owned enterprise (SOE) by Chinese local government; and Non-SOE is an issuer not owned by the government. We also control other variables, including bond yield spread, credit rating, long term debt to assets, natural $\log$ of total assets, market to boo ratio, and return on equity. We use robust standard error to calculate $t$ value. T-statistics are presented in parentheses. The industry is the fixed effect. *, ** or *** signifies significance at the $10 \%, 5 \%$, or $1 \%$ level, respectively.

\begin{tabular}{|c|c|c|c|}
\hline VARIABLES & $\begin{array}{l}\text { (1) } \\
\text { Ret }\end{array}$ & $\begin{array}{l}(2) \\
\text { Ret }\end{array}$ & $\begin{array}{l}(3) \\
\text { Ret }\end{array}$ \\
\hline LG-SOE & & $\begin{array}{l}-0.119 \\
(-0.18)\end{array}$ & \\
\hline Non-SOE & & $\begin{array}{c}-1.837 * * \\
(-2.36)\end{array}$ & \\
\hline IGG & & & $\begin{array}{c}0.295 * * \\
(2.23)\end{array}$ \\
\hline Yield Spread & $\begin{array}{c}0.373 * \\
(1.80)\end{array}$ & $\begin{array}{c}0.520 * * \\
(2.43)\end{array}$ & $\begin{array}{c}0.927 * * * \\
(3.73)\end{array}$ \\
\hline Rating & $\begin{array}{c}0.758 * \\
(1.94)\end{array}$ & $\begin{array}{l}0.439 \\
(1.09)\end{array}$ & $\begin{array}{c}1.211 * * * \\
(2.61)\end{array}$ \\
\hline LT Debt/Assets & $\begin{array}{l}0.438 \\
(0.19)\end{array}$ & $\begin{array}{l}-0.104 \\
(-0.04)\end{array}$ & $\begin{array}{l}-1.547 \\
(-0.56)\end{array}$ \\
\hline Log (Assets) & $\begin{array}{l}0.206 \\
(0.92)\end{array}$ & $\begin{array}{c}0.207 \\
(0.88)\end{array}$ & $\begin{array}{c}0.161 \\
(0.61)\end{array}$ \\
\hline $\mathrm{M} / \mathrm{B}$ & $\begin{array}{c}2.818 * * * \\
(15.61)\end{array}$ & $\begin{array}{c}2.852 * * * \\
(15.47)\end{array}$ & $\begin{array}{c}2.902 * * * \\
(11.50)\end{array}$ \\
\hline ROE & $\begin{array}{c}0.077 * * \\
(2.19)\end{array}$ & $\begin{array}{c}0.094 * * * \\
(2.65)\end{array}$ & $\begin{array}{c}0.113^{* * *} * \\
(2.70)\end{array}$ \\
\hline Constant & $\begin{array}{c}-10.775^{* * * *} \\
(-3.30)\end{array}$ & $\begin{array}{c}-8.832 * * \\
(-2.42)\end{array}$ & $\begin{array}{c}-12.719 * * * \\
(-3.12)\end{array}$ \\
\hline Observations & 11,055 & 11,055 & 7,016 \\
\hline R-squared & 0.051 & 0.052 & 0.053 \\
\hline
\end{tabular}


Figure 1. Operating Performance and Issuer Types
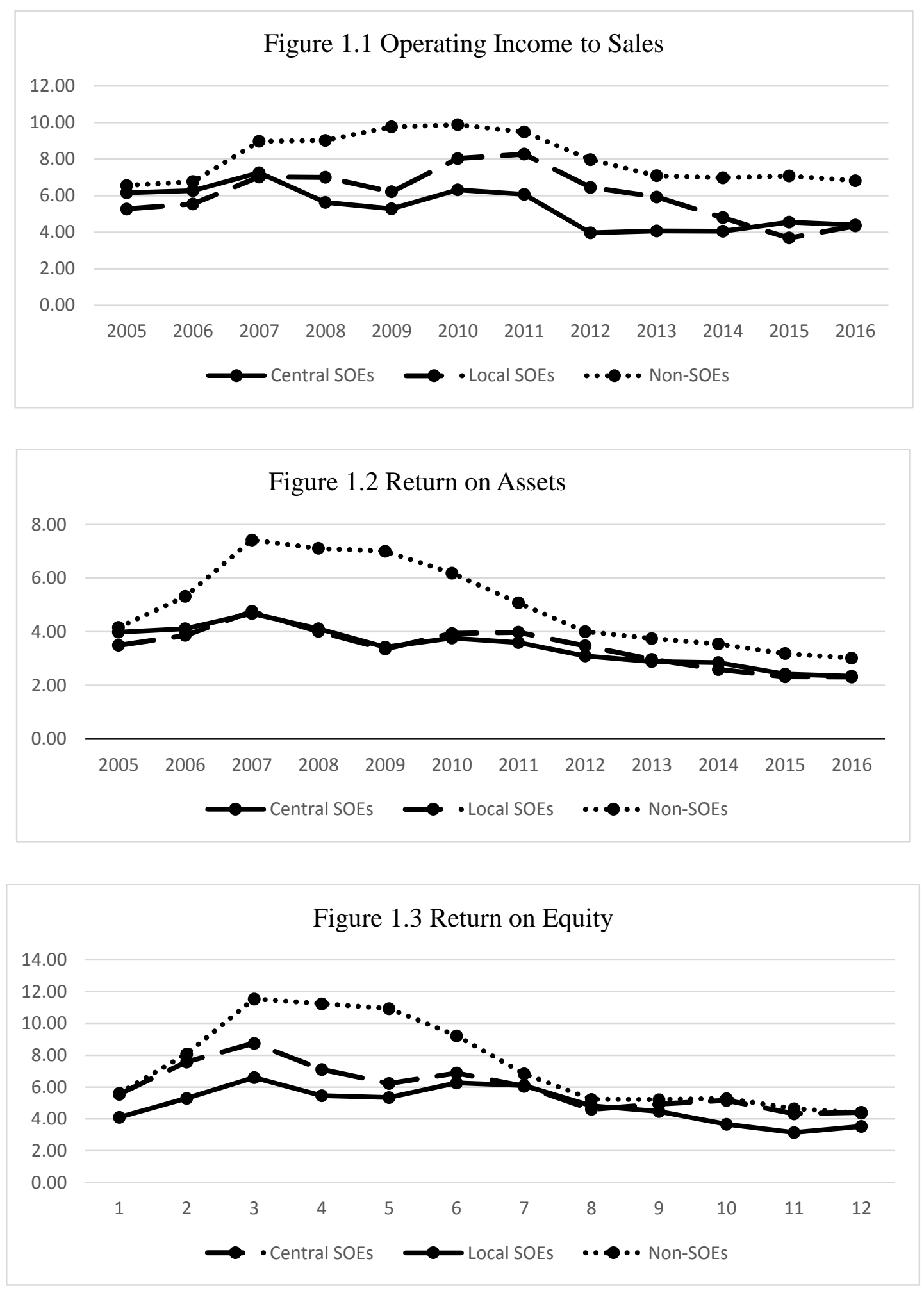
Figure 2. Stock Performance and Issuer Types

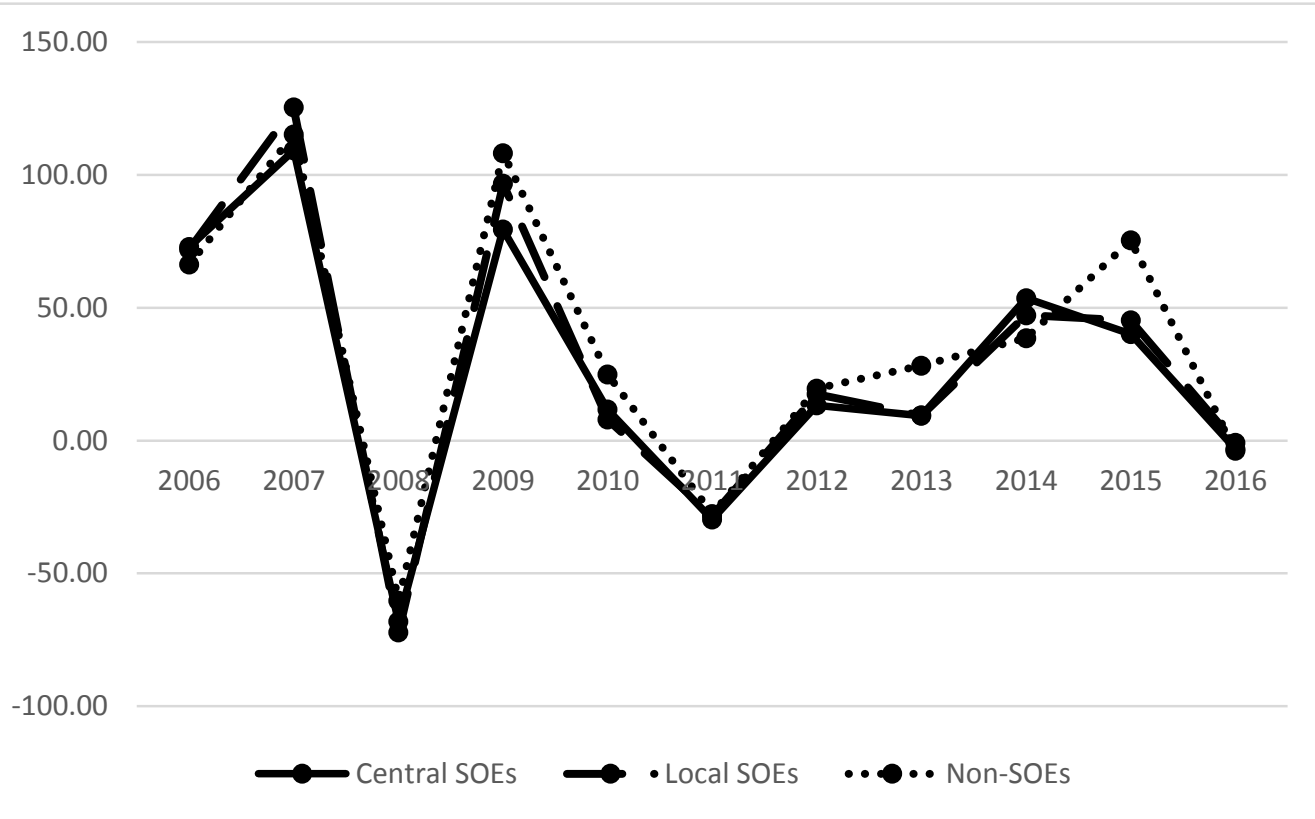

